\author{
University of São Paulo \\ "Luiz de Queiroz" College of Agriculture
}

\begin{abstract}
Abundance, genetic diversity and persistence of Metarhizium spp. fungi from soil of strawberry crops and their potential as biological control agents against the two-spotted spider mite Tetranychus urticae
\end{abstract}

Thiago Rodrigues de Castro

Thesis presented to obtain the degree of Doctor in Science. Area: Entomology

Piracicaba

2016 


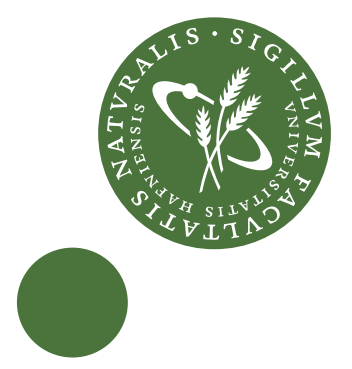

Abundance, genetic diversity and persistence of Metarhizium spp. fungi from soil of strawberry crops and their potential as biological control agents against the two-spotted spider mite Tetranychus urticae

PhD THESIS 2016 - THIAGO RODRIGUES DE CASTRO

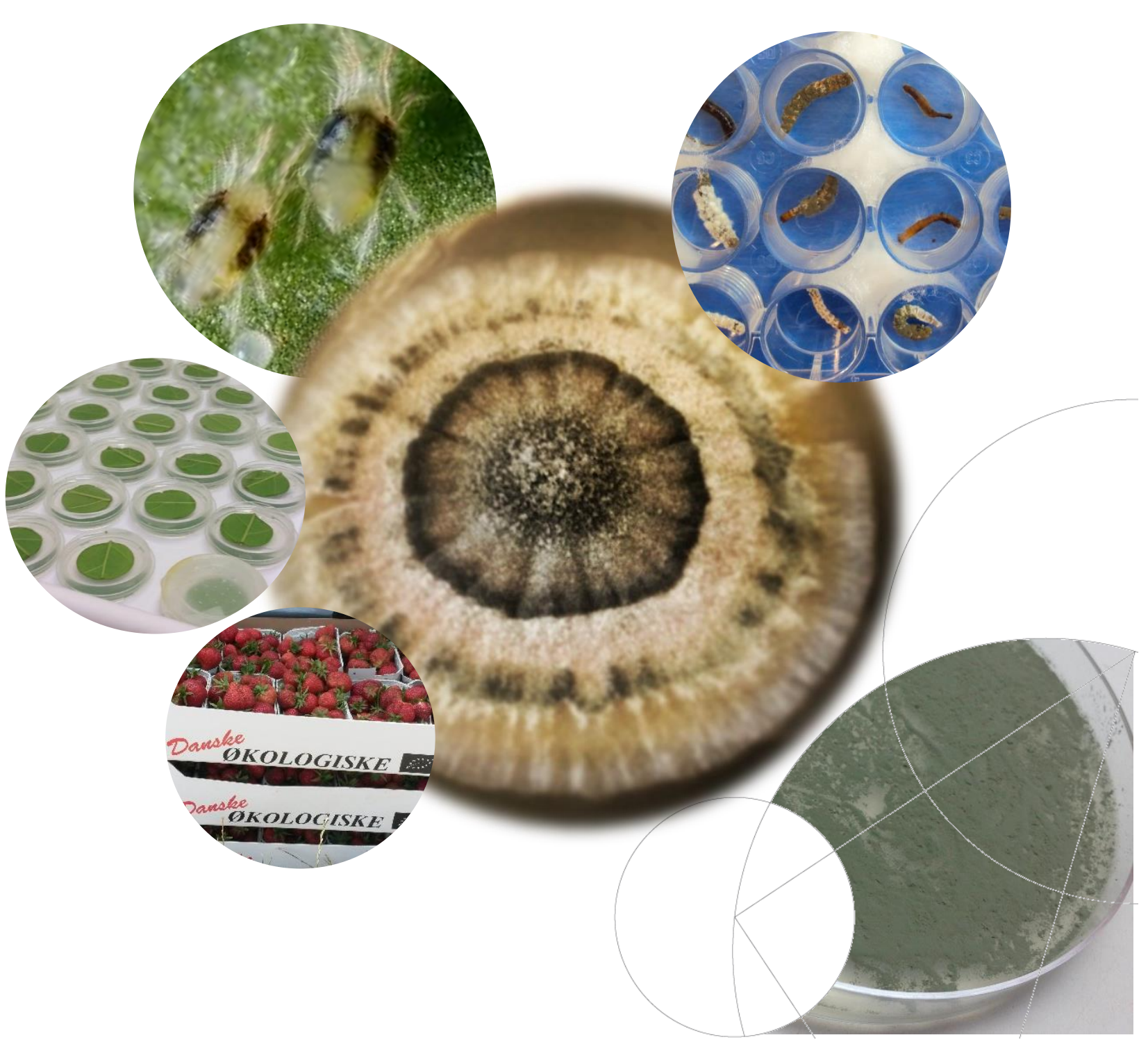


Institution: University of Copenhagen, Faculty of Science

Department: $\quad$ Department of Plant and Environmental Sciences (PLEN)

Author: $\quad$ Thiago Rodrigues de Castro

Title:

Abundance, genetic diversity and persistence of Metarhizium spp. fungi from soil of strawberry crops and their potential as biological control agents against the two-spotted spider mite Tetranychus urticae.

Academic advisors: Jørgen Eilenberg

Italo Delalibera Júnior

Submitted:

02 March 2016

To be defended

20 April 2016

Assessment committee

Gilberto José de Moraes: Prof. of the Department of Entomology and Acarology, University of São Paulo, ESALQ.

Marcos Rodrigues de Faria: EMBRAPA Recursos Genéticos e Biotecnologia

Luis Garrigós Leite: Instituto Biológico

Karina Lucas da Silva Brandão: University of São Paulo, Centro de Energia Nuclear na Agricultura

Annette Bruun Jensen: Prof. Department of Plant and Environmental Sciences, University of Copenhagen 
Thiago Rodrigues de Castro

Bachelor in Biological Sciences

\begin{abstract}
Abundance, genetic diversity and persistence of Metarhizium spp. fungi from soil of strawberry crops and their potential as biological control agents against the two-spotted spider mite Tetranychus urticae
\end{abstract}

Advisers:

Prof. Dr. ITALO DELALIBERA JÚNIOR

Prof., DSc \& PhD JøRGEN EILENBERG

Thesis presented to obtain the degree of Doctor in Science. Area: Entomology 


\section{Dados Internacionais de Catalogação na Publicação DIVISÃO DE BIBLIOTECA - DIBD/ESALQ/USP}

Castro, Thiago Rodrigues de

Abundance, genetic diversity and persistence of Metarhizium spp. fungi from soil of strawberry crops and their potential as biological control agents against the two-spotted spider mite Tetranychus urticae / Thiago Rodrigues de Castro. - - Piracicaba, 2016.

100 p. : il.

Tese (Doutorado) - - Escola Superior de Agricultura "Luiz de Queiroz".

1. Controle microbiano 2. Marcadores microssatélites 3. Diversidade de fungos 4. Virulência 5. Rizosfera. 6. Patologia de insetos. I. Título

CDD 632.6542

C355a

"Permitida a cópia total ou parcial deste documento, desde que citada a fonte - $\mathrm{O}$ autor" 


\section{IMBICONT Improved biological control for IPM in fruits and berries}

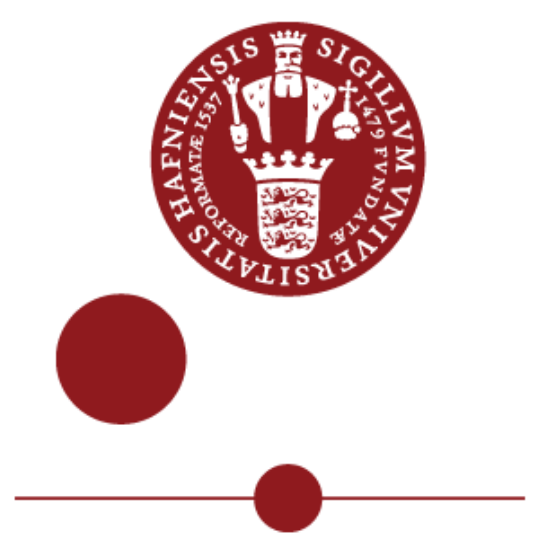

UNIVERSITY OF COPENHAGEN
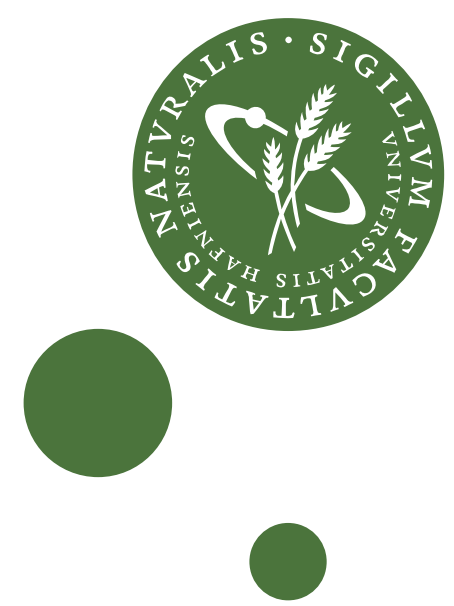

FACULTY OF SCIENCE
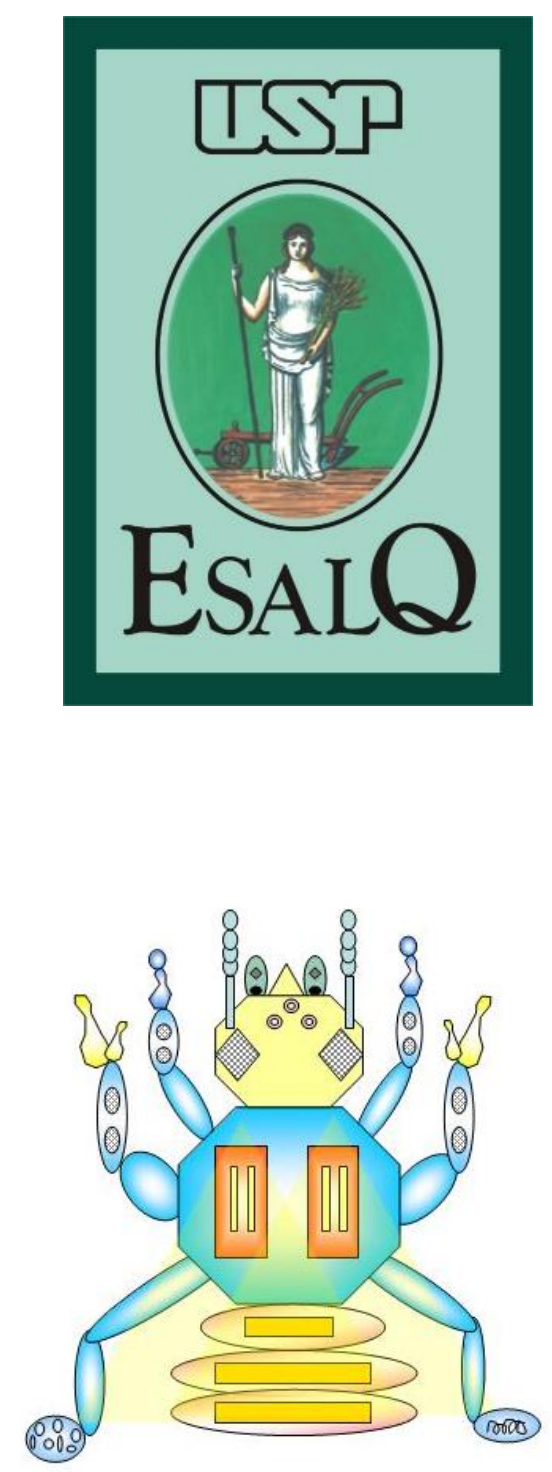

Laboratório de Patologia e Controle Microbiano de Insetos 
To everyone that believed in me, in special to my parents, Idário and Sonia and to my sisters, Tatiana and Adriana.

Without your support and inspiration, I would have never fulfilled my goals 


\section{ACKNOWLEDGMENTS}

First of all, I want to thank my supervisor team. I want to thank my Brazilian supervisor Prof. Dr. Italo Delalibera Júnior for the teachings and guidance of the last twelve years, as well as the trust, friendship and patience, a lot of patience. My Danish supervisor Prof. Jørgen Eilenberg, for the trust to accept me as a student, for all knowledge shared and for always motivating me with your enthusiasm during my stay in the beautiful Copenhagen, thanks for taking care of me like a family member and thank you for the warm welcome in Denmark.

I need to thank all the Section for Organismal Biology (SOBI) from University of Copenhagen, in special Louise Lee Munk Larsen for technical assistance and the limitless friendship. Without the support of each one of you, this work will never be accomplished, thanks for make me feel a little bit Danish myself, never felt more hygge in my entire life.

I had a wonderful time in my stay in Switzerland and learned a lot about microsatellites with an amazing team from the Jürg Enkerli's Lab at AGROSCOPE, thanks so much for the really warm welcome in Reckenholz.

To all my co-authors, it has been an amazing learning experience, thanks for the infinite patience with the corrections.

A really big thanks for the Brazilian community in University of Copenhagen, it is good to feel Brazilian some times when abroad.

A big special thanks for the team of the Laboratory of Pathology and Microbial Control of Insects - ESALQ/USP, everyone helped me a little bit, and this will not be forgotten. A special thanks for Lívia Maria Alves Porto that was my left arm during my research time in Brazil, thanks for the technical assistance and the friendship.

To Prof. Dr. Clarice Garcia Borges Demétrio and Rafael de Andrade Moral for the great help with my crazy data, without your knowledge in statistics, this will never be a good work.

For all the professors from the department of Entomology and Acarology ESALQ/USP for the shared knowledge during all these years.

Thanks to all my brothers from the República Reserva Alcoológica Biosfera, for the support and fun.

Thanks to Nathalie for her unconditional love and "patience" with me during 2015.

To the endless support of my Family.

I want to take this opportunity to express my gratitude to all people and institutions that make the realization of this work possible. This work was mainly financed by Danish Agency for Science, Technology and Innovation and The São Paulo Research Foundation (through the project IMBICONT: 'Improved biological control for IPM in fruits and berries', project number 0603-00486B and 2011/51556-3 respectively). The first author was a recipient of scholarships from the São Paulo Research Foundation (FAPESP, project number 2013/24430-4 and 2013/10517-0) and National Counsel of Technological and Scientific Development (140553/2012-6).

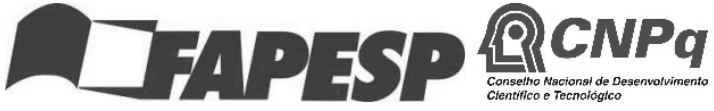


"Do... or do not. There is no try!". 


\section{SUMÁRIO}

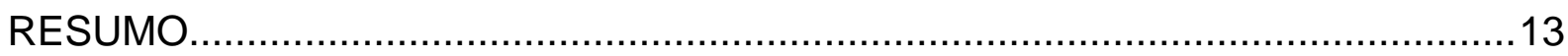

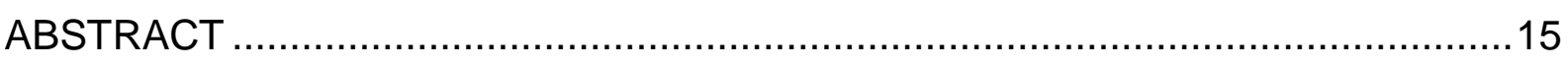

1 INTRODUCTION

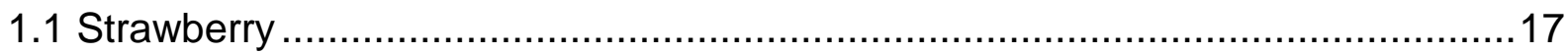

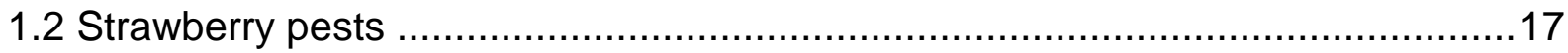

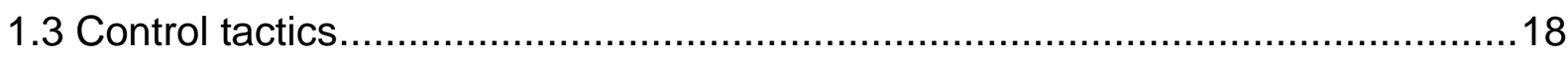

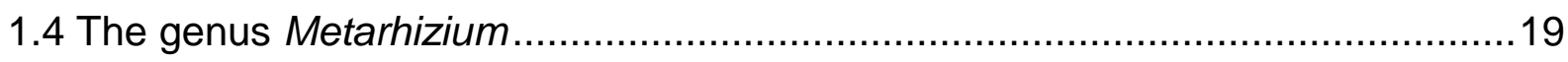

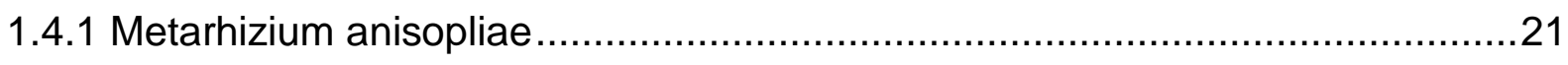

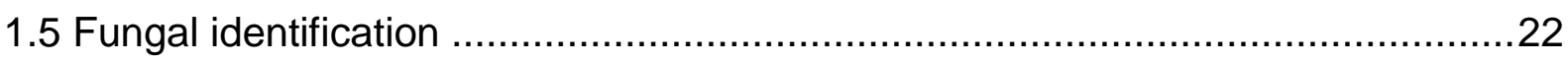

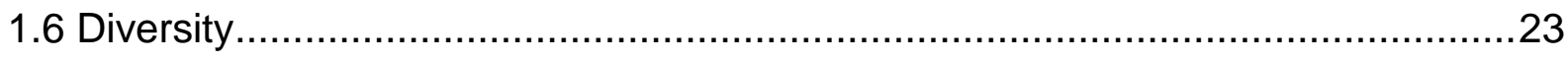

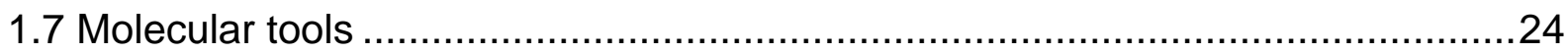

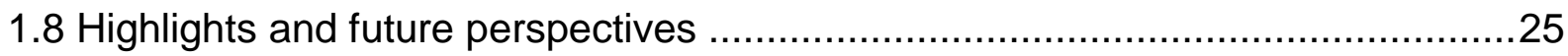

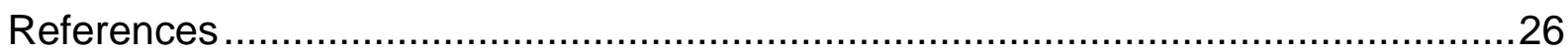

2 PERSISTENCE OF BRAZILIAN ISOLATES OF THE ENTOMOPATHOGENIC FUNGI Metarhizium anisopliae AND M. robertsii IN STRAWBERRY CROP SOIL

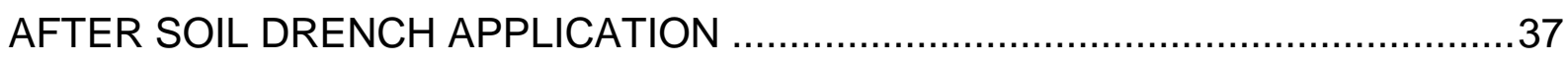

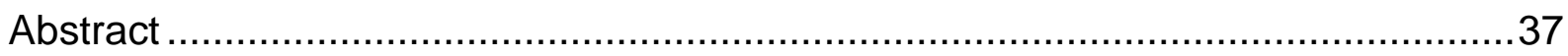

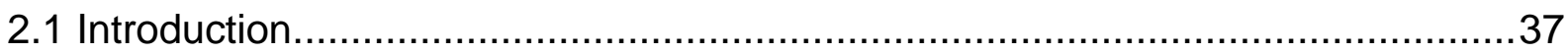

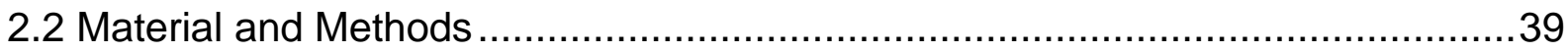

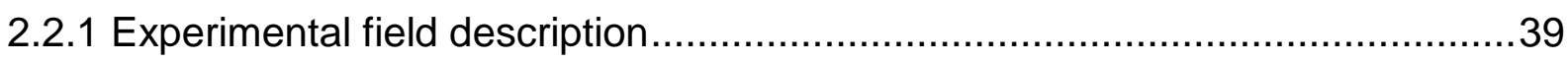

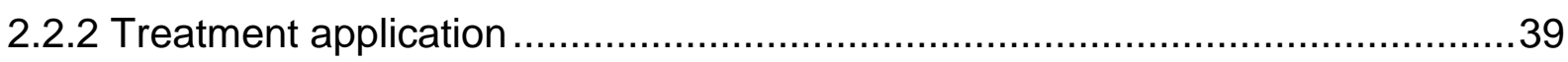

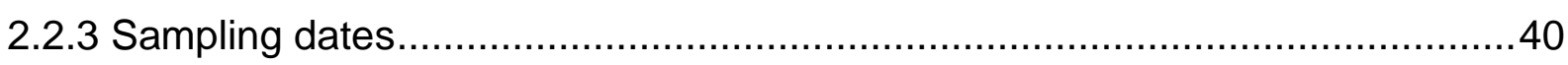

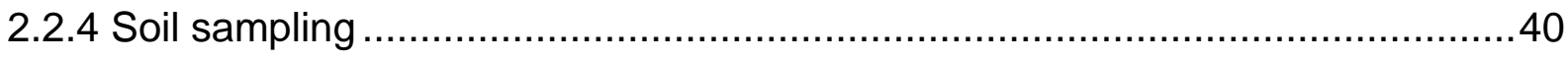

2.2.5 Isolation of entomopathogenic fungi ......................................................... 41

2.2.5.1 Selective agar media ............................................................................

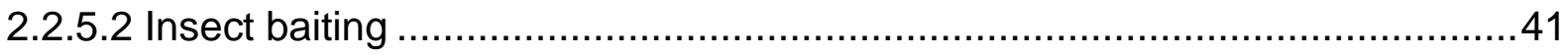

2.2.5.3 Isolation from strawberry rhizospheres ............................................. 42

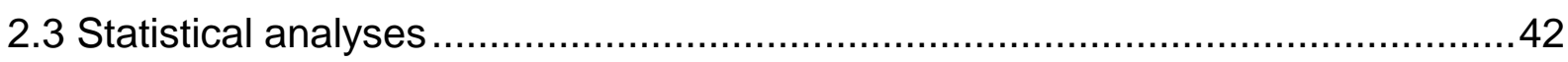

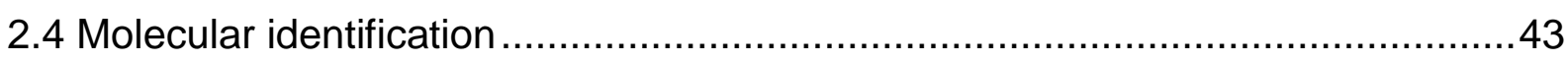

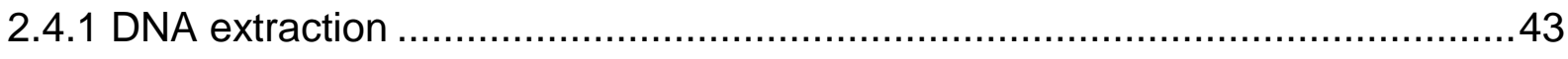

2.4.2 Gene sequencing and SSR marker analyses ...........................................43

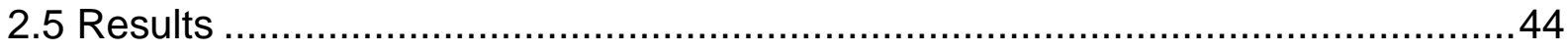




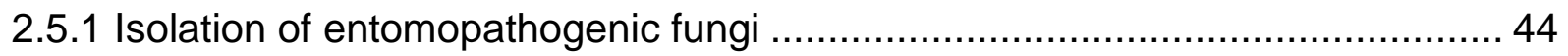

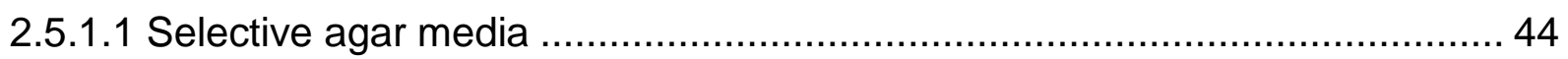

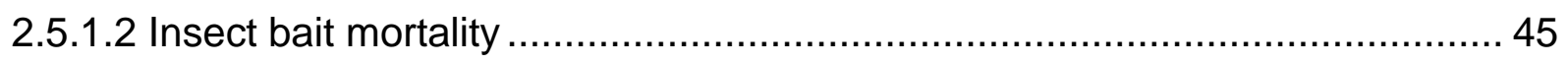

2.5.2 Gene sequencing and SSR marker analyses ............................................. 46

2.5.3 Species and haplotype frequencies ………............................................ 51

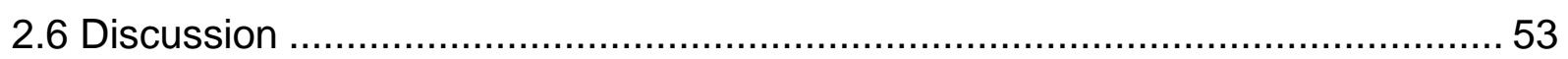

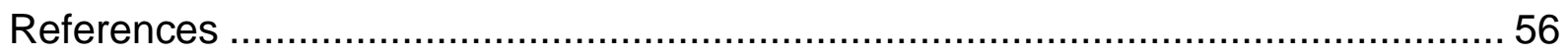

3 DIVERSITY AND ABUNDANCE OF BRAZILIAN AND DANISH Metarhizium spp. IN ORGANIC AND CONVENTIONAL STRAWBERRY CROP SOIL...........................63

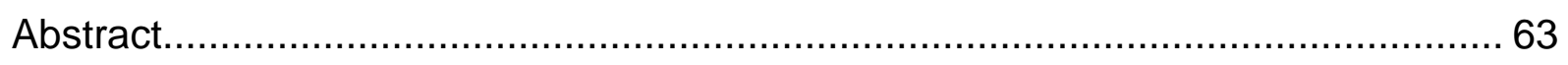

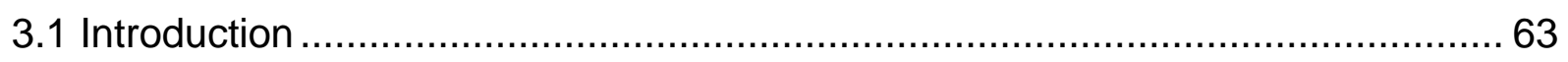

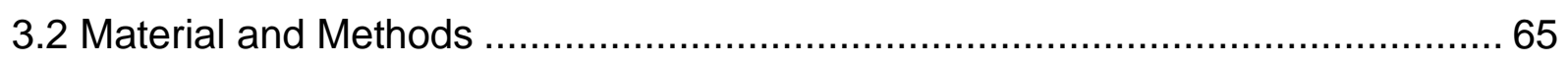

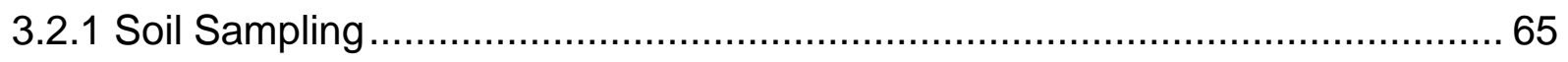

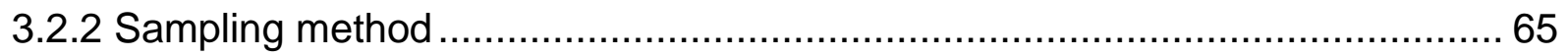

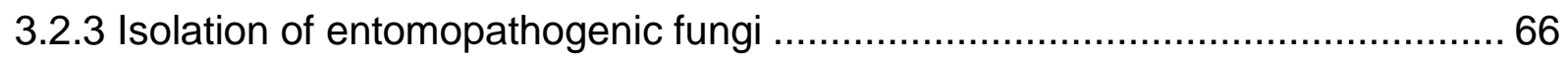

3.2.4 Molecular identification of entomopathogenic Hypocreales fungi ................... 66

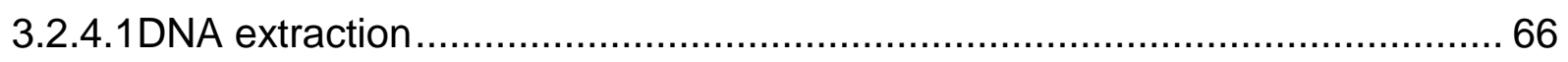

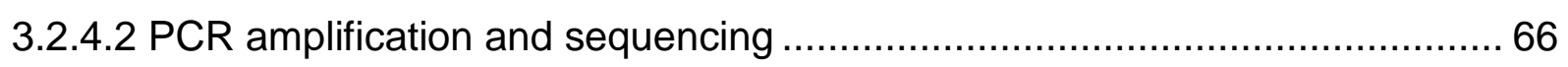

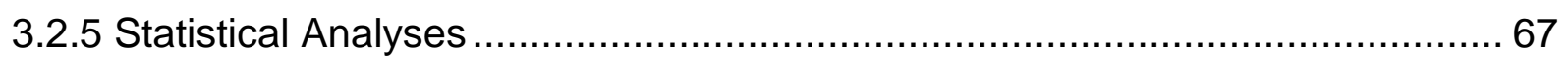

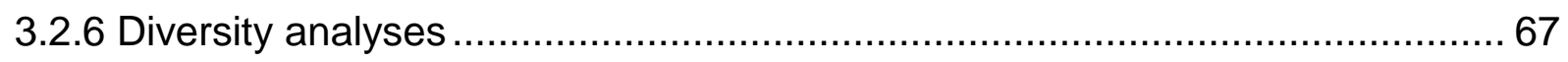

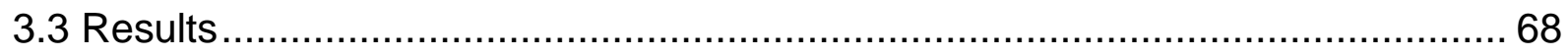

3.3.1 Abundance of Metarhizium spp. in strawberry crops ................................... 68

3.3.2 Diversity of Metharizium spp. in strawberry crops......................................... 70

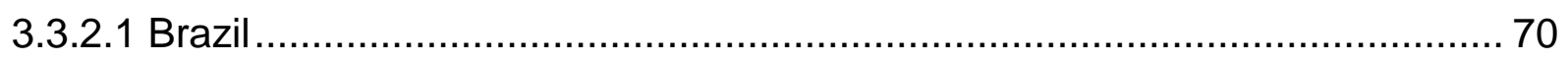

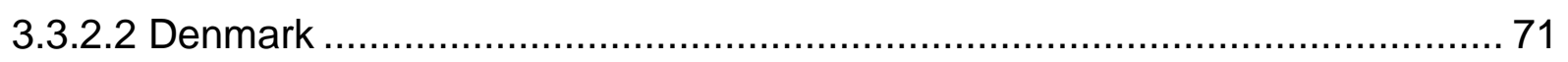

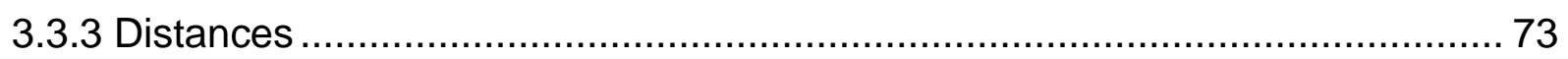

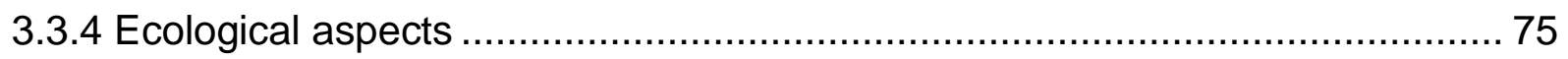

3.3.4.1 Analyses of Molecular Variance .............................................................. 75

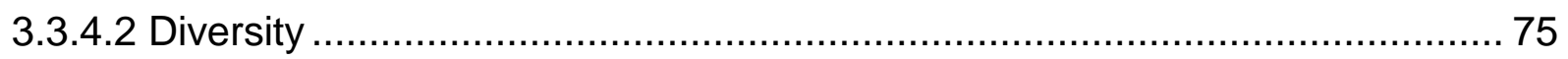

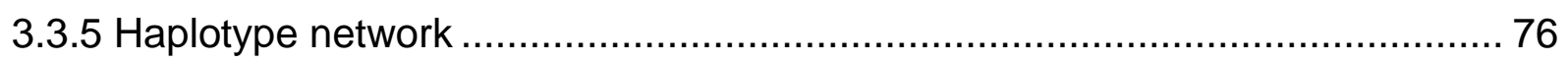

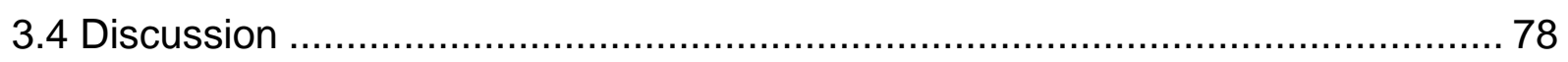

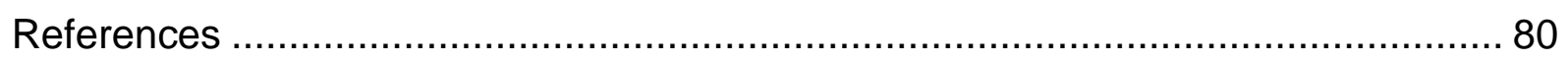

4 EXPLORING THE DIVERSITY OF Metarhizium spp. FROM BRAZIL FOR THE CONTROL OF THE TWO-SPOTTED SPIDER MITE …..................................... 87 


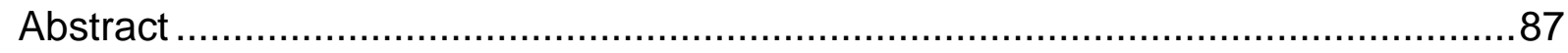

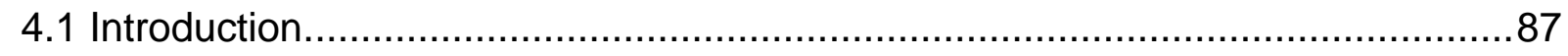

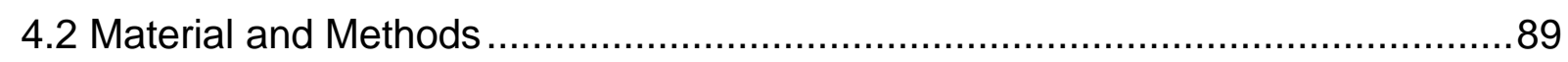

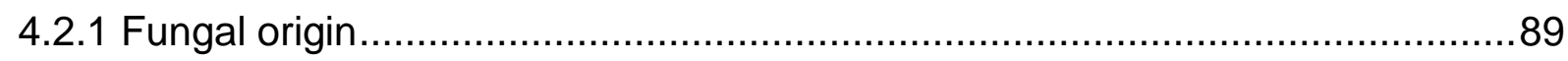

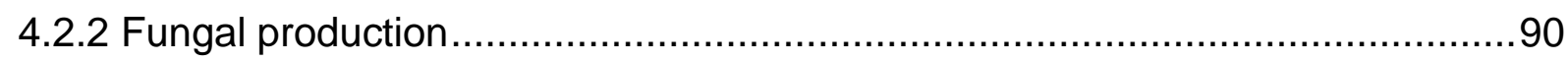

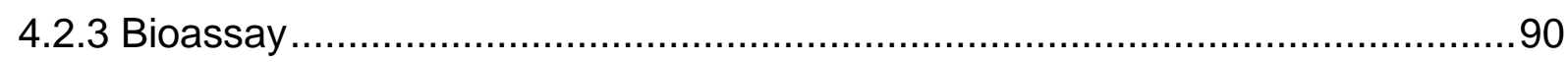

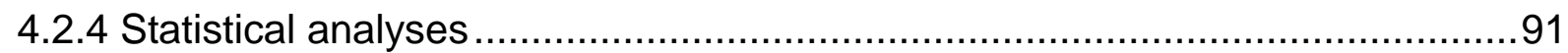

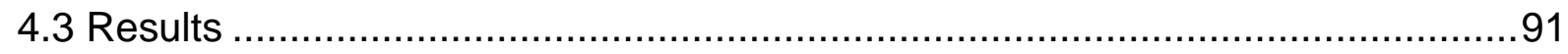

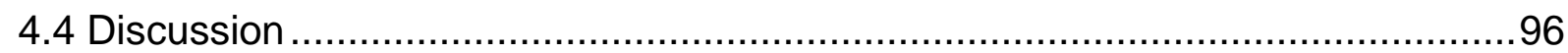

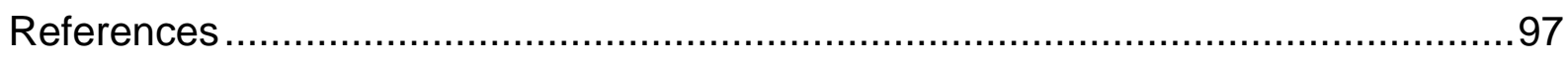




\section{RESUMO}

\section{Abundância, diversidade genética e persistência de fungos Metarhizium spp. isolados de solos de morangueiro e seu potencial como agentes de controle biológico do ácaro rajado, Tetranychus urticae}

A crescente demanda por morangos vem impondo desafios, especialmente quanto ao controle das pragas. Muitos agricultores relatam problemas com a redução da eficiência do controle químico, provavelmente devido à seleção de populações resistentes de insetos e ácaros. Uma alternativa é o uso de controle biológico com fungos entomopatogênicos como ferramenta dentro do manejo integrado de pragas. Metarhizium spp. (Hypocreales: Clavicipitaceae), são fungos entomopatogênicos generalistas com distribuição cosmopolita e que podem causar doenças em um grande número de hospedeiros. Muitos estudos sobre o desenvolvimento de Metarhizium como agente de controle biológico foram realizados, mas este leque de conhecimento está em contraste com a notável falta de investigação sobre a ecologia de Metarhizium nos agroecossistemas. Esta tese teve como objetivo avaliar o estabelecimento, persistência e dispersão destes fungos entomopatogênicos em solo de morangueiro em Inconfidentes, Minas Gerais, Brasil; bem como estudar a diversidade e abundância de espécies de Metarhizium isolados do solo de cultivos orgânico e convencional de morangueiro, e das margens das plantações no Brasil e Dinamarca. A eficácia de novas espécies de Metarhizium, encontradas recentemente no Brasil, foi avaliada contra o ácaro rajado, Tetranychus urticae. Os isolados inoculados de $M$. anisopliae (ESALQ1037) e M. robertsii (ESALQ1426) foram capazes de persistir por até 12 meses após a aplicação no solo, além de dispersar para outras parcelas e colonizar a rizosfera dos morangueiros. Nas parcelas onde ESALQ1037 e ESALQ1426 foram aplicados, 25\% e 87,5\% dos isolados recuperados após 12 meses consistiam dos mesmos isolados inoculados. Uma nova linhagem não taxonomicamente identificada, referida neste trabalho como Metarhizium sp. Indet. 5, foi encontrada nas margens de morangueiros cultivados. A espécie dominante de Metarhizium no Brasil e Dinamarca foi Metarhizium robertsii e M. brunneum, respectivamente. Além disso, Metarhizium pemphigi foi detectado pela primeira vez na Dinamarca neste estudo. Solos de cultivo orgânico de morangueiro em geral apresentaram uma diversidade maior de Metarhizium do que solos de cultivos convencionais. Estes estudos revelaram pela primeira vez o potencial de novas espécies de Metarhizium como agentes de controle biológico do ácaro rajado, sendo o menor tempo letal mediano ( $\mathrm{TL}_{50}=4 \pm 0.17$ dias) observado em ácaros tratados com o isolado ESALQ1638 de Metarhizium sp. indet. 1. Os melhores isolados foram ESALQPL63 de B. bassiana, ESALQ1608 e ESALQ1638 de Metarhizium sp. indet. 1 e ESALQ3069 e ESALQ3222 de M. pingshaense baseado na curva de sobrevivência, mortalidade total, porcentagem de cadáveres esporulados e TL50. O conhecimento da diversidade de Metarhizium spp. e persistência em solos de morango, gerados neste estudo, poderão ser úteis no desenvolvimento de estratégias de conservação e maximizar o controle biológico natural de pragas.

Palavras-chave: Controle microbiano; Marcadores microssatélites; Estrutura da comunidade fúngica; Ecologia de populações; "Insect baiting"; Virulência. 


\begin{abstract}
Abundance, genetic diversity and persistence of Metarhizium spp. fungi from soil of strawberry crops and their potential as biological control agents against the two-spotted spider mite Tetranychus urticae
\end{abstract}

The growing demand for strawberries has imposed challenges, especially regarding the control of pests. Many farmers report problems with reduced chemical control efficiency, probably due to selection of resistant populations of insects and mites. An alternative is the use of biological control using pathogenic fungi as a tool in integrated pest management. Metarhizium spp. (Hypocreales: Clavicipitaceae) are generalist entomopathogenic fungi with worldwide distribution and can cause diseases in a large number of hosts. Many studies on the development of Metarhizium as a biological control agent were performed, but this bulk of knowledge is in remarkable contrast to the lack of research on the fundamental ecology of Metarhizium in agroecosystems. This thesis aimed to evaluate the establishment, persistence and dispersal of these entomopathogenic fungi in strawberry crop soil in Inconfidentes, Minas Gerais, Brazil; and to study the diversity and abundance of species of Metarhizium isolated from organic and conventional strawberry crop soils, and the field margins in Brazil and Denmark. The effectiveness of new species of Metarhizium recently found in Brazil, was evaluated against two spotted spider mite, Tetranychus urticae. Applied isolates of M. anisopliae (ESALQ1037) and M. robertsii (ESALQ1426) were able to persist for up to 12 months after the application within the soil, and disperse to other plots and colonize the rhizosphere of strawberry plants. In the plots where ESALQ1037 and ESALQ1426 were applied, 25\% and 87.5\% of the isolates recovered after 12 months consisted of the same isolates inoculated. A new taxonomically unassigned lineage, referred to as Metarhizium sp. Indet. 5 in this study, was found in strawberry crop margins. The dominant species of Metarhizium in Brazil and Denmark was Metarhizium robertsii and $M$. brunneum respectively. Further, Metarhizium pemphigi was first detected in Denmark in this study. Soil in organically grown strawberries harbored a more diverse population of Metarhizium spp. compared with conventionally grown strawberries. These studies showed for the first time the potential of new species of Metarhizium as spider mite biological control agents, the lowest median lethal time ( $\mathrm{LT}_{50}=4 \pm 0.17$ days) was observed in mites treated with the isolate ESALQ1638 of Metarhizium sp. indet. 1. The best isolates were ESALQPL63 of B. bassiana, ESALQ1608 and ESALQ1638 of Metarhizium sp. indet. 1 and ESALQ3069 and ESALQ3222 of M. pingshaense based on the survival curve, total mortality, percentage of sporulated cadavers and LT50. Knowledge of the diversity of Metarhizium spp. and persistence in strawberry soil generated in this study may be useful in developing conservation strategies and maximize the natural biological pest control.

Keywords: Microbial control; Microsatellite markers; Fungal community structure; Population ecology; Insect baiting; Colony-forming unit; Virulence; Pathogenicity 


\section{INTRODUCTION}

\subsection{Strawberry}

The wild and cultivated species of strawberry had historical ornamental and medicinal purpose, and was widely used in Europe (ASSIS, 2006). The strawberry genotype that is currently cultivated, Fragaria $x$ ananassa (Rosales: Rosacea) had its origins from the inbreed of Fragaria virginiana Mill (originated from North America) and Fragaria chiloensis (Linnaeus) Duchesne, 1766 (originated from Chile). This occurred through commercial plants natural hybridization (REBELO; BALARDIN, 1989; RESENDE et al., 1999; MALAGODI-BRAGA, 2002).

The world's 2013 strawberry production was approximately 7.8 million tons, the biggest producing country was China with a production of 2.9 million tons. Brazil produced more than three thousand tons, producing $8.500 \mathrm{~kg} / \mathrm{ha}$ and Denmark more than six thousand tons producing $6.200 \mathrm{~kg} / \mathrm{ha}$ in 2013 (FAO, 2016). Strawberries for direct consumption is a growing and profitable promising market and normally represents the main crop in the regions that is developed (CRUZ, 1999). However, damage due to pests and diseases cause losses to farmers (WILSON; TISDELL, 2001).

\subsection{Strawberry pests}

Strawberry plants at different growth stages are susceptibility to various pests. The main groups of insects that causes damage are mites, beetles, aphids, leaf cutting ants and caterpillars (FADINI; ALVARENGA, 1999).

Mites are the most harmful group of strawberry crop pests in Brazil (FADINI; ALVARENGA, 1999). Among the mites found in strawberries, the main pests are the red mites Tetranychus cinnabarinus (Boisduval) Boudreaux, 1956, Tetranychus desertorum Banks, 1900 and Tetranychus Iudeni Zacher, 1913); and also the TwoSpotted Spider Mite, Tetranychus urticae Koch, 1836 considered a main pest of strawberry (FADINI; ALVARENGA, 1999; FADINI; PALLINI, 2004; DE MORAES; FLECHTMANN, 2008). Freitas et al. (2011) reported spider mite to be the main problem of strawberry crops in south Minas Gerais state in Brazil. Mites from family Tarsonemidae may also occur in strawberries, for example Phytonemus pallidus (Banks, 1899) and broad mite, Polyphagotarsonemus latus (Banks, 1904) which attack mainly the tip of the plants leaving them wrinkled (FADINI; ALVARENGA, 1999; DE 
MORAES; FLECHTMANN, 2008). Tetranychus urticae is an important pest of more than 150 host plants of economic importance worldwide (JEPPSON et al., 1975). At room temperature, the development from egg to adult is about 10 days and each female may lay up to 100 eggs, allowing the rapid increase in population (MITCHELL, 1973). For these reasons, it is considered one of the most important species of mite pests worldwide (DE MORAES; FLECHTMANN, 2008). According to Chiavegato e Mischan (1981) the potential productivity reduction in strawberry plants can reach up to $80 \%$ in case of high population density of this pest.

\subsection{Control tactics}

Chemical control (also known as conventional control) is the main method of pest control used by most producers that adopt the conventional cropping systems (VAN LEEUWEN et al., 2015). Such systems include the use of chemical pesticides, especially Abamectin, Milbemectin, and Fenpropathrin. However, many producers have had problems with the efficiency of these products, most likely due to selection of resistant populations in strawberry (SATO et al., 2005). Insects and mites can quickly develop resistance to chemical pesticides when they are frequently used and under strong selection pressure that leads to the increasing use of new pesticides and intensive mixing products for satisfactory control.

An alternative to these conventional systems is the use of biological control, which is broadly used in organic farm systems. Biological control can be defined as "the use of living organisms to suppress the population of a specific pest organism, making it less abundant or less damaging then it would otherwise be" (EILENBERG et al., 2001). Insect pathogenic fungi from Ascomycota (genera Metarhizium and Beauveria) were the first pathogens to be used in biological control of arthropods (DAVIDSON, 2012). While research on such fungi aiming to develop products has been intense, less attention has been given to research on the ecology of the fungi. Inconsistent results from biological control experiments in the field might be due to a lack of understanding of the ecology and biology of these fungi (VEGA et al., 2008).

Entomopathogenic fungi are able to penetrate directly into the host cuticle, so there is no need for ingestion by the host as happens with most of other insect pathogens like bacteria and virus (HALL; PAPIEROK, 1982). The infection process of a fungus (exemplified with Metarhizium spp.) to a host can be briefly explained by: 1 . Attachment: the fungal conidia adhere to the host cuticle using a combination of 
hydrophobic interaction and specialized adhesion proteins; 2. Germination and appressoria formation; 3. Penetration through the cuticle, which is mechanical but aided by the production of enzymes including proteases, chitinases and lipases; 4 . Overcoming host defenses: production of destruxins; 5. Proliferation within the host: mainly through the production of blastospores or hyphae; and 6. Outgrowth and production of new infective fungal conidia. Mostly, the fungi require high relative humidity to infect, and this condition is actually found in protected cultivations in greenhouses, or crops that generate a suitable microclimate, as is the case of strawberry (ZIMMERMANN, 2007).

Entomopathogenic fungi are good candidates for implementation in Integrated Pest Management (IPM), a practice increasingly adopted in different agroecosystems, which includes the maintenance of natural enemies within crops. This can be combined with inundative releases of natural enemies. If the use of pesticides is necessary, the decision is always to use efficient products against the pests, but selective, so they do not harm to the natural enemies. Such practices should be adopted with the aim of increasing the maximum production with minimum possible impact on the environment (KOGAN, 1998).

The need to develop alternative control strategies is critical considering the cost, reduced efficiency and environmental impact of pesticides. So it is essential that multiple strategies of biological control are developed that can be used by farmers and incorporated into IPM programs. One option is the use of entomopathogenic fungi, since most of these have a high specificity, proportionating a restricted host range, which results in a low risk to natural enemies such as predators and parasitoids. Even in the case of pathogens with a wider range of hosts, they present a lower risk than pesticides (JACOBSON et al., 2001). Most of the commercially produced fungi are species of Beauveria, Metarhizium, Lecanicillium and Isaria, which are all relatively easy to mass produce (FARIA; WRAIGHT, 2007). Although recent discoveries assign new ecological functions to this group of fungi, it has been broadly studied for its insect control.

\subsection{The genus Metarhizium}

Metarhizium spp. (Hypocreales: Clavicipitaceae), are generalist entomopathogenic fungi with a cosmopolitan distribution occurring in the tropics, temperate, sub-Arctic and sub-Antarctic regions (JARONSKI, 2007; ZIMMERMANN, 
2007). They can cause diseases in a large number of hosts (ROBERTS; HAJEK, 1992), act as plant endophytes by rhizosphere colonization (BEHIE et al., 2012) or in the soil as saprophytic (MEYLING; EILENBERG, 2007). Much effort has been put into research on the development of Metarhizium as biological control agent (for inundation biological control) to be applied in agriculture and forestry. However, this bulk of knowledge is in striking contrast to the lack of research into the fundamental ecology of Metarhizium in agroecosystems.

Metarhizium spp can infect more than 200 species of insects and other arthropods (ROBERTS; HAJEK, 1992). According to Zimmermann (1993), beetles, grasshoppers, leafhoppers and termites represent the most susceptible groups to these fungi. For these reasons, Metarhizium is one of the most studied group of insect pathogens for use in biological pest control.

Temperature, humidity, and UV-radiation are the most important abiotic factors that affect entomopathogenic fungal performance. Temperature can affect Metarhizium spp. germination, hyphal growth and infection rates (KEYSER et al., 2014). Temperature fluctuations have also been shown as one of the primary limiting factors in field release success (NELSON FOSTER et al., 2010; FOSTER et al., 2011). Similarly, UV radiation, especially UV-B radiation can be highly detrimental to conidia survival (BRAGA et al., 2001; RANGEL et al., 2005). Relative humidity is an important factor in determining sporulation, infection, growth and conidial longevity (DAOUST; ROBERTS, 1983; MILNER et al., 1997; ARTHURS; THOMAS, 2001; VEGA et al., 2012). These factors are also relevant in understanding the natural distribution and abundance in the field. It is possible to verify that the climate zones have different abiotic factors and this will reflect and have strong influence on abundance and distribution of these fungi. In Fernandes et al. (2008) Metarhizium spp. showed to be less cold tolerant than Beauveria spp., which may explain for example, why Beauveria was isolated all over Finland while Metarhizium spp were mostly recovered from the southern Finland areas (VÄNNINEN, 1996). No Metarhizium isolates were found in one area of southern Alberta, Canada, this is possibly due to the semi-arid and cold area sampled (INGLIS et al., 2008). Some differences in the response to abiotic factors can have direct association with the isolate origin, since isolates sampled from forested areas were more likely to grow at low temperatures while those found in open fields showed a propensity for growth at higher temperatures and were more UV-B tolerant (BIDOCHKA et al., 2001). 
Soil is the most appropriate environment for recovery of these entomopathogenic fungi since it serves as a natural reservoir enabling the survival of fungal propagules when they find a host (MEDO; CAGÁŇ, 2011; VEGA et al., 2012). The entomopathogenic fungi species composition and its occurrence in the soil can be significantly influenced by factors related to soil characteristics, climatic conditions, agricultural inputs and practices (JARONSKI, 2007; MEYLING; EILENBERG, 2007; VEGA et al., 2012). In addition to these factors, the various methods used for isolation of these fungi, (e.g., sampling and isolation method) makes direct comparison between the studies difficult, since until now, these works have shown diverse occurrence patterns.

\subsubsection{Metarhizium anisopliae}

The successful use of this fungus in Brazil started in the 70's as the biological control program of leafhopper in northeast region of Brazil on sugarcane crops (ALVES et al., 2008). Brazil has one of the most successful program using commercial products and non-commercial based in $M$. anisopliae complex that controls 16 leafhoppers (Hemiptera: Cercopidae) including Mahanarva fimbriolata (Stal, 1854) and M. posticata (Stal, 1855) in sugarcane and M. fimbriolata, Deois flavopicta (Stal, 1854) and Notozulia entreriana (Berg, 1879) on pasture (ALVES et al., 2008). This fungus has provided efficient levels of leafhoppers control (LI et al., 2010) and the estimation is that the annual application of this fungi exceeds two million hectares of sugar cane every year (PARRA, 2014).

Due to this success, $M$. anisopliae is the fungus species with the highest number of bio-product registered ( $n=16)$ (AGROFIT) in the Brazilian Ministry of Agriculture, Livestock and Supply (MAPA) beside the fact of being the most commercialized entomopathogen by companies it has a history of being produced on a large scale by sugar cane producers, as non-commercial product (LI et al., 2010).

These products are used mainly on sugarcane crops and pastures. Although the records are restricted to leafhoppers, the application of $M$. anisopliae products had shown good results in the control of other pests like termites, ticks and ants (GARCIA, 2008; CASTILHO et al., 2010; HUSSAIN et al., 2011; QUINELATO et al., 2012). Studies have shown an efficiency of 60 to $100 \%$ in control of leafhoppers pest populations in the sugarcane fields of São Paulo state (DINARDO-MIRANDA et al., 2001; LOUREIRO et al., 2012). Despite the widespread use of M. anisopliae to control 
these pests, little is known about the diversity, distribution and ecology of currently recognized species (BISCHOFF et al., 2009) in natural and agricultural environments in Brazil (REZENDE et al., 2015).

The virulence of different species can vary greatly between different host species (BUTT et al., 1992) because of it, virulence tests towards each insect species of interest become necessary. Additionally, virulence varies among isolates even within the same species of fungus, which complicates even more the appropriate isolate selection for applied use. The variation in virulence is also important when considering pest control strategies, since a very small percentage of all insect species are important pests and some beneficial and natural enemies like pollinators, parasitoids and predators are important to a balanced insect community, they should not be harmed by the applied entomopathogenic fungi, so, it is possible to use this virulence variation as an advantage and a tool in IPM. Although is it clear that the use of entomopathogenic fungi is advantageous for farmers, consumers, and the environment, it is also clear that much research is needed to reach the full potential of these fungi.

Metarhizium spp. can be more abundant than other entomopathogenic fungi in crop fields and open meadows (VÄNNINEN, 1996; BIDOCHKA et al., 1998; QUESADA-MORAGA et al., 2007; SUN et al., 2008). The studies until now reported that Metarhizium spp. have a tendency to be less commonly found in colder regions than in temperate and tropical regions (KLINGEN et al., 2002; INGLIS et al., 2008; SUN; LIU, 2008), this is also supported by laboratory studies which has demonstrated that most species of Metarhizium, with the exception of M. frigidum, do not grow at cold temperatures (FERNANDES et al., 2010a, 2008). It seems Metarhizium spp. distribution is more associated with habitats than with host insects as firstly hypothesized (BIDOCHKA et al., 2001; FISHER et al., 2011; WYREBEK et al., 2011; STEINWENDER et al., 2015), which shows the importance to study ecological aspects of this fungi group in each crop system.

\subsection{Fungal identification}

The morphological identification can be done by the visualization of hyphae, phialides, conidiophore and conidia, through microscope observation. The morphological characteristics can be assessed using identification keys (HUMBER, 2012) 
Recently, in a multilocus phylogenetic study, the fungus previous known as $M$. anisopliae actually comprises a nine species complex: $M$. anisopliae, $M$. guizhouense, M. pingshaense, M. acridum, M. majus, M. lepidiotae, M. brunneum, M. globosum and M. robertsii (BISCHOFF et al., 2009), and M. flavoviridae already known as a different species by its different morphology. In this study, was also highlighted that it is difficult to separate some species of the $M$. anisopliae complex based only on morphological characters, for example, M. anisopliae has identical morphology of $M$. robertsii. They suggest that the most reliable way to distinguish between species within this complex is the use of molecular tools and analyzes. Based on their results, was determined that the $5^{\prime}$ region of the gene for the translational elongation factor (TEF-1 $\alpha$ ) is the most informative region for routine use in species identification within the genus. This region requires only two primers and is easily amplified. Recently Kepler e Rehner (2013) sought to identify new nuclear regions that are more informative for Metarhizium complex. Primers developed for seven new regions were evaluated (MzFG543igs, MzFG546igs, MzBTigs, MzIGS2, MzIGS3, MzIGS5 and MzIGS7) and observed that the combined phylogenetic analysis of these segments provided a satisfactory genealogy for the group.

\subsection{Diversity}

In Brazil, until now 12 species have been reported in different habitats ( $M$. anisopliae, M. acridum, M. majus, M. flavoviride, M. pingshaense, M. robertsii, $M$. brunneum, M. lepidiotae and four undetermined species: Metarhizium sp indet.1, Metarhizium sp indet.2 and Metarhizium sp indet.3, Metarhizium sp indet.4 (ROCHA et al., 2009, 2013; LOPES; MESQUITA, 2013; LOPES; SOUZA, 2013; LOPES et al., 2014; REZENDE, 2014; REZENDE et al., 2015; ZANARDO, 2015; IWANICKI, 2016), but few studies were conducted to understand the diversity of these fungi. The knowledge until now allows inferring that the diversity of Metarhizium species recovered from soil is high. $M$. robertsii and $M$. anisopliae are the two most common species in Brazil, being $M$. robertsii commonly recovered in five Brazilian biomes soils under different vegetation covers (ROCHA et al., 2013; REZENDE, 2014; ZANARDO, 2015). Metarhizium anisopliae is the species most commonly found infected insects (ALVES et al., 2004; LOPES; MESQUITA, 2013; REZENDE et al., 2015; IWANICKI, 2016). Unlike the high species diversity in soil, it was only observed one $M$. anisopliae clade naturally infecting root-leafhopper (REZENDE et al., 2015). 
The Danish diversity of Metarhizium is lower than the Brazilian and six species are reported until now in different agroecosystems: M. brunneum, M. robertsii, $M$. majus, M. guizhouense and $M$. flavoviride. Different diversity was found between the studies, predominance of $M$. brunneum was found in most of the works performed in the country (MEYLING et al., 2011; STEINWENDER et al., 2014, 2015) and Keyser et al. (2015) found majority of $M$. flavoviridae. These differences in the composition of the populations could be due to that plants can have some sort of interaction with the surrounding soil environment and recruit fungal associates or even determine the composition of Metarhizium populations depending on the established crop (STEINWENDER et al., 2015).

\subsection{Molecular tools}

With advances in molecular biology techniques, a new research niche has been gaining momentum in recent years for entomopathogenic fungi. Molecular markers are precise tools, able to detect DNA polymorphisms in different populations of a species, therefore, considered an ideal technique to monitor and study the ecology of naturally occurring entomopathogenic fungi and applied isolates in the agricultural fields. Molecular techniques have been applied in ecological studies and virulence of entomopathogenic fungi, especially Metarhizium spp., which is the most studied genera in molecular and biochemical level (ZIMMERMANN, 2007). Genetic diversity and population structure of this fungus has been recently studied to understand the relationship of different genotypes with the host and / or habitat on a regional or global scale, and allows you to monitor your persistence and behavior in the environment that was introduced. Several methods have been used for gene frequency analysis for genotyping studies such as RFLP (restriction fragment length polymorphism), AFLP (polymorphic amplified fragment length), RAPD (Random Amplified Polymorphic DNA) and microsatellite (SSR - Simple sequence repeat) (ENKERLI; WIDMER, 2009).

A molecular marker is a polymorphic DNA region or "locus" that characterizes the genotype of the individual who owns it. Therefore, molecular markers may be derived from any given molecular data providing a detectable polymorphism among the organisms being compared (SALLES et al., 2003). The uses of microsatellites (SSR) have been gaining prominence in phylogenetic studies of population structure and genetic diversity of fungi. These markers consist of tandem repeated sequences of one to six nucleotides found scattered throughout the genome (JARNE; LAGODA, 
1996). The polymorphism is represented by the variation in the number of repeating elements that constitute the microsatellite, that produce fragments of different sizes (CARRER et al., 2010). SSR markers are characterized for being codominant, abundant, dependent on small amount of individual's DNA and once obtained the primers (markers) informative to one species or isolate, the costs and the demand for hand labor are reduced dramatically (SALLES et al., 2003). In studies of Enkerli et al. (2005) and Oulevey et al. (2009) 41 microsatellites markers were described to recognized $M$. anisopliae, $M$. brunneum and $M$. robertsii, however, more recently, Mayerhofer et al. (2015) also validated between 15-34 microsatellite regions from those 41 previously described to the M. guizhouense, M. lepidiotae, M. majus and $M$. pingshaense.

Studies using microsatellites markers for Metarhizium spp. isolates differentiation showed the efficiency of this technique and can therefore be considered as an effective monitoring tool to studies of fungi application in the field (BECERRA VELÁSQUEZ et al., 2007; STEINWENDER et al., 2014; KEPLER et al., 2015). However, few studies were done in Brazil using DNA sequences obtained from a gene for haplotype and nucleotide diversity studies until now.

\subsection{Highlights and future perspectives}

The use of microorganisms to control pest insects is an important part of current and future crop protection. Understanding the fundamental ecology of these organisms is vital to their successful use. For example, research regarding their natural occurrence, persistence and pathogenicity of new species greatly enhances the potential for more efficient utilization in pest regulation. This thesis advances the current scientific knowledge regarding the ecology and biological control use of Metarhizium spp. fungi in several areas:

- Persistence and dispersal was confirmed up to one year after application of two isolates of Metarhizium spp. in a strawberry crop in Brazil and rhizosphere colonization was detected.

- A new taxonomically unassigned lineage, referred to as Metarhizium sp. Indet. 5 was found in the margins of conventional strawberry management in Brazil. 
- Metarhizium robertsii is the dominant species of the Metarhizium community found in strawberry crop soil in Brazil which were different form the Danish diversity where $M$. brunneum was the dominant species.

- Metarhizium pemphigi was detected for the first time in Denmark.

- Organically management system seems to improve the diversity and the crop margins soil seems to contribute (by exchange of species) with the regulation of the fungi community inside the crop.

- The new species of Metarhizium showed good potential as biological control agents

Probably, one of the most important components of any research is not the conclusion generated but rather the perspectives and new hypothesis that the conclusions leads to. Based on the observations of this thesis there are several research questions that should be addressed in the future, including:

- Worldwide survey studies that attempt to clarify the distribution and occurrence of Metarhizium spp. in agriculture. These studies should highlight habitat associations as well seeking to understand what characteristics promote higher density or diversity in particular areas. Essential to these studies is to continue to develop the molecular based ecological tools, like SSR markers (microsatellites) to discriminate genotypic diversity within all Metarhizium species.

- Field studies to evaluate the effectiveness of the new Metarhizium species, found in recent bioprospection studies against pest insects. These studies should not only evaluate infectivity, but also the fungal persistence in the field, and effects of crop type.

- Future studies to better understand if the rhizosphere colonization provides benefits such as plant growth promotion and antagonism towards pests and diseases as has been seen in laboratory studies for other crops.

\section{References}

AGROFIT. Sistema de agrotóxicos fitossanitários. Disponível em: $<$ http://extranet.agricultura.gov.br/agrofit_cons/principal_agrofit_cons>. Acesso em: 27 jan. 2016. 
ALVES, S.B.; LOPES, R.B.; VIEIRA, S.A.; TAMAI, M.A. Fungos entomopatogênicos usados no controle de pragas na América Latina. In: ALVES, S.B.; LOPES, R.B. (Ed.). Controle microbiano de pragas na América Latina. Piracicaba: FEALQ, 2008. p. 69-110.

ALVES, L.F.A.; ALVES, V.S.; BRESSAN, D.F.; NEVES, P.M.O.J.; ALVES, S.B. Ocorrência de Metarhizium anisopliae (Metsch.) Sorok. em adultos de cascudinho (Alphitobius diaperinus) (Panzer) (Coleoptera: Tenebrionidae) em aviários comerciais em Cascavel, PR. Neotropical Entomology, Londrina, v. 33, n. 6, p. 793-795, 2004.

ARTHURS, S.; THOMAS, M.B. Effect of dose, pre-mortem host incubation temperature and thermal behaviour on host mortality, mycosis and sporulation of metarhizium anisopliae var. acridum in schistocerca gregaria. Biocontrol Science and Technology, Oxford, v. 11, n. 3, p. 411-420, 2001.

ASSIS, M. Produção de plantas e matrizes. In: CARVALHO, S.P. (Ed.). Boletim do morango: cultivo convencional, segurança alimentar, cultivo orgânico. Belo Horizonte: FAEMG, 2006. p. 23-25.

BECERRA VELÁSQUEZ, V.; PAREDES CÁRCAMO, M.; ROJO MERIÑO, C; FRANCE IGLESIAS, A.; FRANCO DURÁN, J. Intraspecific differentiation of Chilean isolates of the entomopathogenic fungi Metarhizium anisopliae var. anisopliae as revealed by RAPD, SSR and ITS markers. Genetics and Molecular Biology, Ribeirão Preto, v. 30, n. 1, p. 89-99, 2007.

BEHIE, S.W.; ZELISKO, P.M.; BIDOCHKA, M.J. Endophytic insect-parasitic fungi translocate nitrogen directly from insects to plants. Science, Washington, v. 336, n. 6088, p. 1576-1577, 2012.

BIDOCHKA, M.J.; KASPERSKI, J.E.; WILD, G.A.M. Occurrence of the entomopathogenic fungi Metarhizium anisopliae and Beauveria bassianain soils from temperate and near-northern habitats. Canadian Journal of Botany, Ottawa, v. 76, n. 7, p. 1198-1204, 1998.

BIDOCHKA, M.J.; KAMP, A.M.; LAVENDER, T.M.; DEKONING, J.; DE CROOS, J.N. Habitat association in two genetic groups of the insect-pathogenic fungus metarhizium anisopliae: uncovering cryptic species? Applied and Environmental Microbiology, Washington, v. 67, n. 3, p. 1335-42, 2001.

BISCHOFF, J.F.; REHNER, S.A.; HUMBER, R.A. A multilocus phylogeny of the Metarhizium anisopliae lineage. Mycologia, New York, v. 101, n. 4, p. 512-30, 2009.

BRAGA, G.U.L.; FLINT, S.D.; MESSIAS, C.L.; ANDERSON, A.J.; ROBERTS, D.W. Effect of UV-B on conidia and germlings of the entomopathogenic hyphomycete Metarhizium anisopliae. Mycological Research, Cambridge, v. 105, n. 7, p. 874882, 2001. 
BUTT, T.M.; BARRISEVER, M.; DRUMMOND, J.; SCHULER, T.H.; TILLEMANS, F.T.; WILDING, N. Pathogenicity of the entomogenous, hyphomycete fungus, Metarhizium anisopliae against the chrysomelid beetles Psylliodes chrysocephala and Phaedon cochleariae. Biocontrol Science and Technology, Oxford, v. 2, n. 4, p. 327-334, 1992.

CARRER, H.; BARBOSA, A.L.; RAMIRO, D. Biotecnologia na agricultura. Estudos Avançados, São Paulo, v. 24, n. 70, p. 149-164, 2010.

CASTILHO, A.M.C.; FRAGA, M.E.; AGUIAR-MENEZES, E.L.; ROSA, C.A.R. Selection of Metarhizium anisopliae and Beauveria bassiana isolates pathogenic to Atta bisphaerica and Atta sexdens rubropilosa soldiers under laboratory conditions. Ciência Rural, Santa Maria, v. 40, n. 6, p. 1243-1249, 2010.

CHIAVEGATO, L.G.; MISCHAN, M.M. Efeito do Tetranychus (T.) urticae (Koch, 1836) Boudreaux \& Dosse, 1963 (Acari, Tetranychidae) na produção do morangueiro (Fragaria sp.) cv. 'Campinas. Científica, Sâo Paulo, v. 9, n. 2, p. 257-266, 1981.

CRUZ, P.C.A situação da cultura do morangueiro no Estado de São Paulo. In: DUARTE FILHO, J.; CANÇADO, G.M.A.; REGINA, M.A.; ANTUNES, L.E.C.; FADINI, M.A.M. (Ed.). Morango: tecnologia de produção e processamento. Caldas: Ed.Agropecuária, 1999. p. 129-130.

DAOUST, R.A.; ROBERTS, D.W. Studies on the prolonged storage of Metarhizium anisopliae conidia: effect of temperature and relative humidity on conidial viability and virulence against mosquitoes. Journal of Invertebrate Pathology, San Diego, v. 41, n. 2, p. 143-150, 1983.

DAVIDSON, E.W. History of insect pathology. In: VEGA, F.E.; KAYA, H.K. (Ed.). Insect pathology. $2^{\text {nd }}$ ed. San Diego: Academic Press, 2012. chap. 2, p. 13-28.

DE MORAES, G.J.; FLECHTMANN, C.H.W. Manual de acarologia: acarologia básica e ácaros de plantas cultivadas no Brasil. Ribeirão Preto: Holos, 2008. $308 \mathrm{p}$.

DINARDO-MIRANDA, L.L.; FERREIRA, J.M.G.; CARVALHO, P.A.M. Influência da época de colheita e do genótipo de cana-de-açúcar sobre a infestação de Mahanarva fimbriolata (Stål)(Hemíptera: Cercopidae). Neotropical Entomology, Londrina, v. 30, p. 145-149, 2001.

EILENBERG, J.; HAJEK, A.; LOMER, C. Suggestions for unifying the terminology in biological control. BioControl, Dordrecht, v. 46, n. 4, p. 387-400, 2001.

ENKERLI, J.; WIDMER, F. Molecular ecology of fungal entomopathogens: molecular genetic tools and their applications in population and fate studies. BioControl, Dordrecht, v. 55, n. 1, p. 17-37, 2009. 
ENKERLI, J.; KÖLLIKER, R.; KELLER, S.; WIDMER, F. Isolation and characterization of microsatellite markers from the entomopathogenic fungus Metarhizium anisopliae. Molecular Ecology Notes, Oxford, v. 5, n. 2, p. 384-386, 2005.

FADINI, M.A.M.; ALVARENGA, D.A. Pragas do morangueiro. Informe Agropecuário, Belo Horizonte, v. 20, n. 198, p. 69-74, 1999.

FADINI, M.A.M.; PALLINI, A. Controle de ácaros em sistema de produção integrada de morango. Revista Ciência Rural, Santa Maria, v. 34, n. 4, p. 1271-1277, 2004.

FAO. FAOSTAT. 2016. Disponível em: <http://faostat3.fao.org/>. Acesso em: 21 Jan. 2016.

FARIA, M.R.D.; WRAIGHT, S. P. Mycoinsecticides and mycoacaricides: a comprehensive list with worldwide coverage and international classification of formulation types. Biological Control, Orlando, v. 43, n. 3, p. 237-256, 2007.

FERNANDES, E.K.; RANGEL, D.E.; MORAES, A.M.; BITTENCOURT, V.R.; ROBERTS, D.W. Cold activity of Beauveria and Metarhizium, and thermotolerance of Beauveria. Journal of Invertebrate Pathology, San Diego, v. 98, n. 1, p. 69-78, 2008.

FISHER, J.J.; REHNER, S.A.; BRUCK, D.J. Diversity of rhizosphere associated entomopathogenic fungi of perennial herbs, shrubs and coniferous trees. Journal of Invertebrate Pathology, San Diego, v. 106, n. 2, p. 289-95, 2011.

FOSTER, R.N.; JARONSKI, S.; REUTER, K.C.; BLACK, L.R.; SCHLOTHAUER, R.; HARPER, J.; JECH, L.E. Simulated aerial sprays for field cage evaluation of Beauveria bassiana and Metarhizium brunneum (Ascomycetes: Hypocreales) against Anabrus simplex (Orthoptera: Tettigoniidae) in Montana. Biocontrol Science and Technology, Oxford, v. 21, n. 11, p. 1331-1350, 2011.

FREITAS, J.A.; ROCHA, L.C.D.; COSTA, R.; MORAES, G.J. Produtores de morango no município de Bom Repouso relatam Tetranychus urticae Koch como principal problema da cultura. 2011. Campinas. Resumos... São Paulo: In: III SIMPÓSIO BRASILEIRO DE ACAROLOGIA em CD-ROM, 2011. p. 1.

GARCIA, M.V. Aplicação do fungo Metarhizium Anisopliae em pastagem visando o controle do carrapato Boophilus Microplus em bovinos. 2008. 45 p. (Doutorado em Microbiologia Agropecuária) - Faculdade de Ciências Agrárias e Veterinárias, Universidade Estadual Paulista "Júlio de Mesquita Filho", Jaboticabal.

HALL, R.A.; PAPIEROK, B. Fungi as biological-control agents of arthropods of agricultural and medical importance. Parasitology, Cambridge, v. 84, p. 205-240, Apr. 1982.

HUMBER, R.A. Identification of entomopathogenic fungi. In: LACEY, L.A. (Ed.). Manual of techniques in invertebrate pathology. $2^{\text {nd }}$ ed. Dordrecht: Springer, 2012. p. 151-187. 
HUSSAIN, A.; AHMED, S.; SHAHID, M. Laboratory and field evaluation of Metarhizium anisopliae var. anisopliae for controlling subterranean termites. Neotropical Entomology, Londrina, v. 40, n. 2, p. 244-250, 2011.

INGLIS, G.D.; DUKE, G.M.; GOETTEL, M.S.; KABALUK, J.T. Genetic diversity of Metarhizium anisopliae var. anisopliae in southwestern British Columbia. Journal of Invertebrate Pathology, San Diego, v. 98, n. 1, p. 101-13, 2008.

IWANICKI, N.S. Monitoramento de Metarhizium spp. (Hypocreales: Clavicipitaceae) por marcadores moleculares em plantios de cana-de-açúcar. 2016. 68 p. Dissertação (Mestrado em Entomologia) - Escola Superior de Agricultura "Luiz de Queiroz", Universidade de São Paulo, Piracicaba, 2016.

JACOBSON, R.J.; CHANDLER, D.; FENLON, J.; RUSSELL, K.M. Compatibility of Beauveria bassiana (Balsamo) vuillemin with Amblyseius cucumeris Oudemans (Acarina : Phytoseiidae) to control Frankliniella occidentalis Pergande (Thysanoptera : Thripidae) on cucumber plants. Biocontrol Science and Technology, Oxford, v. 11, n. 3, p. 391-400, 2001.

JARNE, P.; LAGODA, P.J.L. Microsatellites, from molecules to populations and back. Trends in Ecology \& Evolution, Amsterdam, v. 11, n. 10, p. 424-429, 1996.

JARONSKI, S.T. Soil ecology of the entomopathogenic Ascomycetes: a critical examination of what we (think) we know. In: EKESI, S.; MANIANIA, N.K. (Ed.). Use of entomopathogenic fungi in biological pest management. Kerala: Research Signpost, 2007. p. 91-144.

JEPPSON, L.R.; KEIFER, H.H.; BAKER, E.W. Mites injurious to economic plants. Berkeley: University of California Press, 1975. 641p.

KEPLER, R.M.; REHNER, S.A. Genome-assisted development of nuclear intergenic sequence markers for entomopathogenic fungi of the Metarhizium anisopliae species complex. Molecular Ecology Resources, Oxford, v. 13, n. 2, p. 210-7, 2013.

KEPLER, R.M.; UGINE, T.A.; MAUL, J.E.; CAVIGELLI, M.A.; REHNER, S.A. Community composition and population genetics of insect pathogenic fungi in the genus Metarhizium from soils of a long-term agricultural research system.

Environmental Microbiology, Oxford, v. 17, n. 8, p. 2791-804, 2015.

KEYSER, C.A.; DE FINE LICHT, H.H.; STEINWENDER, B.M.; MEYLING, N.V. Diversity within the entomopathogenic fungal species Metarhizium flavoviride associated with agricultural crops in Denmark. BMC Microbiol, London, v. 15, n. 1, p. 249, 2015.

KEYSER, C.A.; FERNANDES, É.K.K.; RANGEL, D.E.N.; ROBERTS, D.W. Heatinduced post-stress growth delay: a biological trait of many Metarhizium isolates reducing biocontrol efficacy? Journal of Invertebrate Pathology, San Diego, v. 120, p. 67-73, 2014. 
KLINGEN, I.; EILENBERG, J.; MEADOW, R. Effects of farming system, field margins and bait insect on the occurrence of insect pathogenic fungi in soils. Agriculture, Ecosystems \& Environment, Zurich, v. 91, n. 1/3, p. 191-198, 2002.

KOGAN, M. Integrated pest management: historical perspectives and contemporary developments. Annual Review of Entomology, Stanford, v. 43, n. 43, p. 243-270, 1998.

LI, Z.Z.; ALVES, S.B.; ROBERTS, D.W.; FAN, M.Z.; DELALIBERA, I.; TANG, J.; LOPES, R.B.; FARIA, M.; RANGEL, D.E.N. Biological control of insects in Brazil and China: history, current programs and reasons for their successes using entomopathogenic fungi. Biocontrol Science and Technology, Oxford, v. 20, n. 2, p. 117-136, 2010.

LOPES, R.B.; SOUZA, D.A.; OLIVEIRA, C.M.; FARIA, M. Genetic diversity and pathogenicity of Metarhizium spp. associated with the white grub Phyllophaga capillata (Blanchard) (Coleoptera: Melolonthidae) in a soybean field. Neotropical Entomology, Londrina, v. 42, n. 4, p. 436-438, 2013.

LOPES, R.B.; MESQUITA, A.L.M.; TIGANO, M.S.; SOUZA, D.A.; MARTINS, I.; FARIA, M. Diversity of indigenous Beauveria and Metarhizium spp. in a commercial banana field and their virulence toward Cosmopolites sordidus (Coleoptera: Curculionidae). Fungal Ecology, Manchester, v. 6, n. 5, p. 356-364, 2013.

LOPES, R.B.; FARIA, M.; SOUZA, D.A.; BLOCH, C. JR.; SILVA, L.P.; HUMBER, R.A. MALDI-TOF mass spectrometry applied to identifying species of insectpathogenic fungi from the Metarhizium anisopliae complex. Mycologia, New York, v. 106, n. 4, p. 865-878, 2014.

LOUREIRO, E.S.; BATISTA FILHO, A.; ALMEIDA, J.E.M.; MENDES, J.M.; PESSOA, L.G.A. Eficiência de isolados de Metarhizium anisopliae (metsch.) sorok. no controle da cigarrinha-da-raiz da cana-de-açúcar, Mahanarva fimbriolata (stal, 1854) (Hemiptera: Cercopidae), em condições de campo. Arquivos do Instituto Biológico, São Paulo, v. 79, p. 47-53, 2012.

MALAGODI-BRAGA, K.S. Estudo de agentes polinizadores em cultura de morango (Fragaria x ananassa Duchesne - Rosaceae). 2002. 110 p. Tese (Doutorado em Ecologia) - Instituto de Biociências, Universidade de São Paulo, São Paulo, 2002.

MAYERHOFER, J.; LUTZ, A.; WIDMER, F.; REHNER, S.A.; LEUCHTMANN, A.; ENKERLI, J. Multiplexed microsatellite markers for seven Metarhizium species. Journal of Invertebrate Pathology, San Diego, v. 132, p. 132-134, 2015.

MEDO, J.; CAGÁŇ, L'. Factors affecting the occurrence of entomopathogenic fungi in soils of Slovakia as revealed using two methods. Biological Control, Orlando, v. 59, n. 2, p. 200-208, 2011. 
MEYLING, N.V.; EILENBERG, J. Ecology of the entomopathogenic fungi Beauveria bassiana and Metarhizium anisopliae in temperate agroecosystems: Potential for conservation biological control. Biological Control, Orlando, v. 43, n. 2, p. 145-155, 2007.

MEYLING, N.V.; THORUP-KRISTENSEN, K.; EILENBERG, J. Below- and aboveground abundance and distribution of fungal entomopathogens in experimental conventional and organic cropping systems. Biological Control, Orlando, v. 59, n. 2, p. 180-186, 2011.

MILNER, R.J.; STAPLES, J.A.; LUTTON, G.G. The effect of humidity on germination and infection of termites by the hyphomycete, Metarhizium anisopliae. Journal of Invertebrate Pathology, San Diego, v. 69, n. 1, p. 64-9, 1997.

MITCHELL, R. Growth and population dynamics of a spider mite (Tetranychus Urticae K., Acarina: Tetranychidae). Ecology, Tempe, v. 54, n. 6, p. 1349, 1973.

NELSON FOSTER, R.; JARONSKI, S.; REUTER, K.C.; BLACK, L.R.; SCHLOTHAUER, R. Explaining mycoinsecticide activity: poor performance of spray and bait formulations of Beauveria bassiana and Metarhizium brunneum against mormon cricket in field cage studies. Journal of Orthoptera Research, Philadelphia, v. 19, n. 2, p. 303-313, 2010.

OULEVEY, C.; WIDMER, F.; KÖLLIKER, R.; ENKERLI, J. An optimized microsatellite marker set for detection of Metarhizium anisopliae genotype diversity on field and regional scales. Mycological Research, Cambridge, v. 113, n. 9, p. 1016-1024, 2009.

PARRA, J.R.P. Biological control in Brazil: an overview. Scientia Agricola, Piracicaba, v. 71, n. 5, p. 420-429, 2014.

QUESADA-MORAGA, E.; NAVAS-CORTES, J.A.; MARANHAO, E.A.; ORTIZURQUIZA, A.; SANTIAGO-ALVAREZ, C. Factors affecting the occurrence and distribution of entomopathogenic fungi in natural and cultivated soils. Mycological Research, Cambridge, v. 111, n. 8, p. 947-966, 2007.

QUINELATO, S.; GOLO, P.S.; PERINOTTO, W.M.; SA, F.A.; CAMARGO, M.G.; ANGELO, I.C.; MORAES, A.M.; BITTENCOURT, V.R. Virulence potential of Metarhizium anisopliae s.I. isolates on Rhipicephalus (Boophilus) microplus larvae. Veterinary parasitology, Amsterdam, v. 190, n. 3/4, p. 556-565, 2012.

RANGEL, D.E.; BRAGA, G.U.; ANDERSON, A.J.; ROBERTS, D.W. Variability in conidial thermotolerance of Metarhizium anisopliae isolates from different geographic origins. Journal of Invertebrate Pathology, San Diego, v. 88, n. 2, p. 116-125, 2005.

REBELO, J.A.; BALARDIN, R.S. A cultura do morangueiro. Florianópolis: EMPASC, 1989. 33 p. (Boletim Técnico, 46). 
RESENDE, L.M.A.; MASCARENHAS, M.H.T.; PAIVA, B.M. Panorama da produção e comercialização de morango. Informe Agropecuário, Belo Horizonte, v. 20, p. 5-19, 1999.

REZENDE, J.M. Diversidade filogenética e expressão de genes de virulência de Metarhizium com ênfase em isolados brasileiros associados a cultura da canade-açúcar. 2014. 138 p. Tese (Doutorado em Entomologia) - Escola Superior de Agricultura "Luiz de Queiroz", Universidade de São Paulo, Piracicaba, 2014.

REZENDE, J.M.; ZANARDO, A.B.R.; LOPES, M.D.; DELALIBERA, I.; REHNER, S.A. Phylogenetic diversity of Brazilian Metarhizium associated with sugarcane agriculture. Biocontrol, Dordrecht, v. 60, n. 4, p. 495-505, 2015.

ROBERTS, D.W.; HAJEK, A.E. Entomopathogenic fungi as bioinsecticides. In: LEATHAM, F.G. (Ed.). Frontiers in industrial mycology. New York: Springer US, 1992. p.144-159.

ROBERTS, D.W.; ST. LEGER, R.J. Metarhizium spp., cosmopolitan insectpathogenic fungi. Advances in applied microbiology, San Diego, v. 54, p. 1-70, 2004.

ROCHA, L.F.; INGLIS, P.W.; HUMBER, R.A.; KIPNIS, A.; LUZ, C. Occurrence of Metarhizium spp. in Central Brazilian soils. Journal of Basic Microbiology, Berlin, v. 53, n. 3, p. 251-259, 2013.

ROCHA, L.F.N.; TAI, M.H.H.; SANTOS, A.H.D.; ALBERNAZ, D.A.D.S.; HUMBER, R.A.; LUZ, C. Occurrence of invertebrate-pathogenic fungi in a Cerrado ecosystem in Central Brazil. Biocontrol Science and Technology, Oxford, v. 19, n. 5, p. 547-553, 2009.

SALLES, G.B.C.; CIAMPI, A.Y.; MORETZSOHN, M.C.; AMARAL, Z.P.S.; BRONDANI, R.V. Marcadores microssatélites em espécies vegetais. Revista Biotecnologia Ciência e Desenvolvimento, Brasília, v. 30, p. 46-50, 2003.

SATO, M.E.; DA SILVA, M.Z.; RAGA, A.; DE SOUZA FILHO, M.F. Abamectin resistance in Tetranychus urticae Koch (Acari: Tetranychidae): selection, crossresistance and stability of resistance. Neotropical Entomology, Londrina, v. 34, n. 6, p. 991-998, 2005.

ST LEGER, R.J. Studies on adaptations of Metarhizium anisopliae to life in the soil. Journal of Invertebrate Pathology, San Diego, v. 98, n. 3, p. 271-276, 2008.

STEINWENDER, B.M.; ENKERLI, J.; WIDMER, F.; EILENBERG, J.; KRISTENSEN, H.L.; BIDOCHKA, M.J.; MEYLING, N.V. Root isolations of Metarhizium spp. from crops reflect diversity in the soil and indicate no plant specificity. Journal of Invertebrate Pathology, San Diego, v. 132, p. 142-148, 2015. 
STEINWENDER, B.M.; ENKERLI, J.; WIDMER, F.; EILENBERG, J.; THORUPKRISTENSEN, K.; MEYLING, N.V. Molecular diversity of the entomopathogenic fungal Metarhizium community within an agroecosystem. Journal of Invertebrate Pathology, San Diego, v. 123, p. 6-12, 2014.

SUN, B.-D.; LIU, X.-Z. Occurrence and diversity of insect-associated fungi in natural soils in China. Applied Soil Ecology, Amsterdam, v. 39, n. 1, p. 100-108, 2008.

SUN, B.-D.; YU, H.-Y.; CHEN, A.J.; LIU, X.-Z. Insect-associated fungi in soils of field crops and orchards. Crop Protection, Guildford, v. 27, n. 11, p. 1421-1426, 2008.

VAN LEEUWEN, T.; TIRRY, L.; YAMAMOTO, A.; NAUEN, R.; DERMAUW, W. The economic importance of acaricides in the control of phytophagous mites and an update on recent acaricide mode of action research. Pesticide Biochemistry and Physiology, San Diego, v. 121, p. 12-21, 2015.

VÄNNINEN, I. Distribution and occurrence of four entomopathogenic fungi in Finland: effect of geographical location, habitat type and soil type. Mycological Research, Cambridge, v. 100, n. 1, p. 93-101, 1996.

VEGA, F.E.; MEYLING, N.V.; LUANGSA-ARD, J.J.; BLACKWELL, M. Fungal entomopathogens. In: VEGA, F.E.; KAYA, H.K. (Ed.). Insect pathology. San Diego: Academic Press, 2012. chap. 6, p.171-220.

VEGA, F.E.; POSADA, F.; CATHERINE AIME, M.; PAVA-RIPOLL, M.; INFANTE, F.; REHNER, S.A. Entomopathogenic fungal endophytes. Biological Control, Orlando, v. 46, n. 1, p. $72-82,2008$.

WILSON, C.; TISDELL, C. Why farmers continue to use pesticides despite environmental, health and sustainability costs. Ecological Economics, Amsterdam, v. 39, n. 3, p. 449-462, 2001.

WYREBEK, M.; HUBER, C.; SASAN, R.K.; BIDOCHKA, M.J. Three sympatrically occurring species of Metarhizium show plant rhizosphere specificity. Microbiology, New York, v. 157, n. 10, p. 2904-11, 2011.

ZANARDO, A.B.R. Abundância de fungos entomopatogênicos da ordem Hypocreales e diversidade genética de Metarhizium spp. isolados de amostras de solo de áreas representativas de cinco biomas brasileiros. 2015. 154 p. Tese (Doutorado em Entomologia) - Escola Superior de Agricultura "Luiz de Queiroz", Universidade de São Paulo, Piracicaba, 2015.

ZIMMERMANN, G. The entomopathogenic fungus Metarhizium anisopliae and its potential as a biocontrol agent. Pesticide Science, Oxford, v. 37, n. 4, p. 375-379, 1993.

Review on safety of the entomopathogenic fungus Metarhizium anisopliae.

Biocontrol Science and Technology, Oxford, v. 17, n. 9, p. 879-920, 2007. 
Manuscript 1

TITLE: Persistence of Brazilian isolates of the entomopathogenic fungi Metarhizium anisopliae and $M$. robertsii in strawberry crop soil after soil drench application

Thiago Castro ${ }^{1,3}$, Johanna Mayerhofer²; Jürg Enkerli²; Jørgen Eilenberg ${ }^{3}$; Nicolai V. Meyling ${ }^{3}$, Rafael de Andrade Moral $^{4}$, Clarice Garcia Borges Demétrio ${ }^{4}$ \& Italo Delalibera Jr. ${ }^{1}$

${ }^{1}$ Department of Entomology and Acarology, ${ }_{4}^{4}$ Department of Exact Sciences, ESALQUniversity of São Paulo; Av Padua Dias, 11 - P.O. Box 9 - 13418-900, Piracicaba-SP; Brazil.

2 Molecular Ecology, Institute for Sustainability Sciences, Agroscope, Reckenholzstrasse 191, 8046 Zurich, Switzerland

${ }^{3}$ Department of Plant and Environmental Sciences, University of Copenhagen, Thorvaldsensvej 40, 1871 Frederiksberg C, Denmark

*Corresponding author. Email: thiago.castro@usp.br 


\title{
2 PERSISTENCE OF BRAZILIAN ISOLATES OF THE ENTOMOPATHOGENIC FUNGI Metarhizium anisopliae AND $M$. robertsii IN STRAWBERRY CROP SOIL AFTER SOIL DRENCH APPLICATION
}

\begin{abstract}
Establishment, persistence and dispersal of the entomopathogenic fungi Metarhizium anisopliae (ESALQ1037) and M. robertsii (ESALQ1426) (Ascomycota: Hypocreales) were investigated in the soil and rhizosphere following soil drench application in strawberries between 2012 and 2013 at a single location in Inconfidentes, Minas Gerais, Brazil. Metarhizium spp. isolates $(n=108)$ were collected using selective agar media and insect bait methods, and characterized by sequence analysis of 5' -TEF (elongation factor 1- $\alpha$ ) and MzFG543igs intergenic region and by multilocus simple sequence repeat (SSR) analysis. Both applied fungal isolates were frequently recovered, suggesting that they were able to establish and disperse within the soil, showing rhizosphere competence. Persistence within the soil and rhizosphere for both fungi was confirmed up to 12 months after application. In the plots where ESALQ1037 and ESALQ1426 were applied, 25\% and $87.5 \%$ of the respective isolates recovered after 12 months consisted of the same isolates inoculated. Metarhizium robertsii was the most abundant species in the agroecosystem studied representing $77.8 \%$ of the isolates recovered across all sample dates.
\end{abstract}

Keywords: Microbial control; Microsatellite markers; Fungal community structure

\subsection{Introduction}

The world's strawberry production was approximately 7.8 million tons in 2013 and Brazil produced more than three thousand tons in 2013, with a yield of 8,500 $\mathrm{Kg} / \mathrm{ha}$ (FAO, 2016). Strawberries (Fragaria $x$ ananassa Duch.; Rosales: Rosacea) produced for direct consumption, are a growing, and promising market in Brazil, with profit margins at the point of sale around $20 \%$ with a current price of the final product of approx. USD 4.4/Kg (AGRA-FNP-PESQUISAS, 2015). However, damage from pests and diseases cause significant losses for farmers (WILSON; TISDELL, 2001).

The high load of chemical pesticides used in the Brazilian conventional strawberry production system is of concern, especially regarding negative impacts on the environment and natural enemies of agricultural pests (SATO et al., 2007). Several studies have demonstrated that fungicides, and in some instances herbicides, can significantly reduce the germination and growth of entomopathogenic fungi (SAMSON et al., 2005; YÁÑEZ; FRANCE, 2010; D'ALESSANDRO et al., 2011). In recent years, it has been observed that strawberry producers have experienced problems with the efficacy of chemical products used in pest control, likely due to the selection of resistant 
populations after prolonged cyclical application (SATO et al., 2005). In addition, the use of chemical control increases the risk of pesticide residues in the fruits, as well as causing health problems for farm workers and the contamination of the environment (MAREDIA, 2003).

A viable alternative to the use of chemical pesticides in strawberry production is biological control, such as the use of entomopathogenic fungi- in particular species of the Ascomycota, which often have a broad host range. The genus Metarhizium (Hypocreales: Clavicipitaceae) contains species which occur naturally within the soil environment (MEYLING; EILENBERG, 2007; VEGA et al., 2009; RUDEEN et al., 2013; STEINWENDER et al., 2014), from which they can be recovered. It has been suggested that Metarhizium spp. use the soil as a reservoir, ensuring long-term persistence, even when crops and insects are not present in the field (KLINGEN; HAUKELAND, 2006).

Much effort has been put into the research and development of Metarhizium spp. as biological control agents (for inundation biological control) to be applied in agriculture and forestry (VEGA et al., 2012). Brazil has a long history of using M. anisopliae as a biocontrol agent especially against spittlebugs (Hemiptera: Cercopoidea) in sugarcane and it is estimated that around two million hectares are treated annually (PARRA, 2014). However, the impact of the aerial application of Metarhizium spp. on the indigenous community of the fungus in the soil still need to be investigated. More recently, an increasing number of studies have demonstrated that Metarhizium spp. benefit plant growth (BEHIE et al., 2012; KHAN et al., 2012; SASAN; BIDOCHKA, 2012; BEHIE; BIDOCHKA, 2014) and are antagonistic towards pests and diseases (SASAN; BIDOCHKA, 2013). Understanding the persistence of Metarhizium in the soil and rhizosphere is important to predict the possible duration of the beneficial effects of soil inoculation.

Molecular markers with high discriminatory power are required when studying behavior and fate of a specific applied fungal isolate in the field. Simple sequence repeats (SSR or microsatellite markers) have proven to be very useful for such purposes and allow for consistent and explicit assessment of isolate identity and persistence (PILZ et al., 2011; STEINWENDER et al., 2014, 2015; KEPLER et al., 2015).

The aim of this study was to evaluate the diversity of Metarhizium spp. and persistence over one year of two Brazilian isolates of Metarhizium (M. anisopliae and 
M. robertsii) applied in a strawberry crop in Minas Gerais state in Brazil. We used SSR markers and phylogenetic analyses of DNA sequence data for characterization of Metarhizium spp. diversity and identification of the two applied fungal isolates among the recovered isolates during the study period.

\subsection{Material and Methods}

\subsubsection{Experimental field description}

The experiment was performed in a strawberry crop in Inconfidentes city in the state of Minas Gerais (MG) Brazil (22¹9'2"S; 46¹9'42"W; 904 m altitude). The strawberry field was not subjected to any treatments with chemical pesticides during the experimental period (May 2012 to August 2013). Approximately 1,520 strawberry seedlings (San Andreas variety) were planted in 12 beds, each $15 \mathrm{~m}$ long, with three rows per bed, with $35 \mathrm{~cm}$ between each plant in May 2012.

\subsubsection{Treatment application}

Two Metarhizium isolates were used:1) M. anisopliae ESALQ1037 isolated in March 1992 in Porto Alegre - RS from Solenopsis sp. (Hymenoptera: Formicidae) and 2) M. robertisii ESALQ1426 - Isolated from soybean crop soil (selective agar medium) in December 2007 in Londrina-PR. Both isolates were deposited at the Collection of Entomopathogenic Microorganisms of the Laboratory of Pathology and Microbial Control of Insects (LPCMI) of the Escola Superior de Agricultura "Luiz de Queiroz" (ESALQ-USP).

Aerial conidia were produced using parboiled rice as the substrate by the plastic bag method (JARONSKI; JACKSON, 2012), and was then mechanically harvested from a fungus-rice mixture using an electrically vibrating sieve containing a set of three $20 \mathrm{~cm}$ round sieves of 32 mesh (pore size $500 \mu \mathrm{m}$ ) (Bertel Indústria Metalúrgica Ltd., Brazil). Afterward, different batches of dried conidial powder $(<13 \%$ $\mathrm{w} / \mathrm{w}$ final moisture) were vacuum sealed and stored at $-20^{\circ} \mathrm{C}$ until use. The conidia viability was determined using the direct count method (ESALQ method), on 4-mL of PDA amended with $0.001 \%(\mathrm{v} / \mathrm{v})$ Derosal® 500 SC (Carbendazim, Bayer CropScience, SP, Brazil) on Rodac $®$ plates (OLIVEIRA et al., 2015).

Immediately after the initial soil sampling in September 2012 for baseline characterization, the two Metarhizium isolates were applied to the experimental 
strawberry field as a randomized block design, containing four blocks with the three treatments (1. M. anisopliae ESALQ1037; 2. M. robertisii ESALQ1426 and 3. Control, water), yielding 12 plots (beds) in total. The fungal suspension (unformulated) was applied by drenching $100 \mathrm{~mL}$ of $1 \times 10^{8}$ viable conidia/mL on the soil surface around each of the 43 strawberry plant in the middle row of the beds after fungal suspension intense homogenization. The control treatment was carried out by applying only water in a similar manner. The application was done between 6 and $7 \mathrm{pm}$, to minimize UV effects on conidial viability.

\subsubsection{Sampling dates}

Soil samples were taken across four sampling time points: 1) September $4^{\text {th }}, 2012$, prior to fungal application in order to characterize the indigenous Metarhizium spp. community in the soil, 2) January $9^{\text {th }}, 2013$; 3) April $16^{\text {th }}, 2013$, and 4) August $21^{\text {th }}, 2013$; to evaluate the persistence of the inoculated isolates at the experimental field site.

\subsubsection{Soil sampling}

Each soil sample was taken to a depth of $10 \mathrm{~cm}$ using a cylindrical sampler (Sondaterra, Brazil) with defined volume $\left(70 \mathrm{~cm}^{3}\right)$. The samples were stored in sterile plastic bags and kept in Styrofoam boxes at approximately $5^{\circ} \mathrm{C}$ during transport to the laboratory following the methodologies pointed out by Inglis et al. (2012).

Each sample consisted of five sub-samples of soil collected in four middle row beds of each treatment per sampling occasion, at $2 \mathrm{~m}$ intervals and $10 \mathrm{~cm}$ away from the strawberry roots. These five combined sub-samples were stored in a sterile plastic bag and manually homogenized, forming one composite sample per bed on each occasion, yielding 48 composite samples per treatment for the total experimental period. In addition, for each sampling occasion, four composite samples were taken from the soil $10 \mathrm{~cm}$ away from the roots of five plants of Bidens pilosa L. (Asterales: Asteraceae) - the most abundant species of spontaneous herb found close to the crop field (maximum $3 \mathrm{~m}$ distance from strawberry plants). This sampling thus generated in total 20 composite samples from the crop margins.

On the last sampling date, we also conducted a root sampling of the strawberry crop by taking five randomly selected whole plants from the middle row of each bed using a garden shovel to pull out the entire root system and adjoining 
rhizospheric soil. These samples were stored as mentioned for the soil samples above. This was carried out to evaluate the rhizosphere colonization of the inoculated Metarhizium species.

\subsubsection{Isolation of entomopathogenic fungi}

The isolations of entomopathogenic fungi from the soil were carried out using selective agar medium and insect baiting.

\subsubsection{Selective agar medium}

The isolation of entomopathogenic fungi using selective agar medium was done using Potato Dextrose Agar (PDA) with 0.002\% Dodine (Dodex 450 SC - Sipcam Isagro, Brazil) and $0.05 \mathrm{~g} / \mathrm{L}$ Gentamicin (Amresco Inc., USA) to reduce the growth of contaminant fungi and bacteria that normally occur in the soil, as described by Fernandes et al. (2010). Each soil sample was homogenized by hand and $10 \mathrm{~g}$ of soil from each composite sample was added to a Scotch tube $(250 \mathrm{ml})$ containing $90 \mathrm{~mL}$ of sterile distilled water and $0.01 \%$ of Tween 80 (Oxiteno, Brazil). The solutions were homogenized on a Vortex-type stirrer and serially diluted $\left(10^{-1}, 10^{-2}, 10^{-3}\right)$. Each dilution $(0.1 \mathrm{ml})$ were then inoculated in duplicates into Petri dishes $(90 \times 15 \mathrm{~mm})$ containing selective medium and incubated in a climatic chamber at a temperature of $25 \pm 1{ }^{\circ} \mathrm{C}$, relative humidity of $70 \pm 10 \%$ and photoperiod of 12 hours for seven days. After this period, Petri dishes were assessed daily for the presence of Metarhizium colonies, of which, identities were confirmed through the analysis of morphological characteristics. Colonies were counted and the number of Colony Forming Unities (CFU) per gram of humid soil were calculated. Pure Metarhizium colonies were obtained by streaking small quantities of conidia using platinum sterile loops in PDA medium plates (INGLIS et al., 2012).

\subsubsection{Insect baiting}

The insect baiting method used was described by Inglis et al. (2012). Soil samples were homogenized by hand using a metal sieve with pore size of $4 \mathrm{~mm}$. One hundred grams of the sieved soil were transferred to transparent plastic pots with 200 $\mathrm{mL}$ capacity with perforated lids. Ten $3^{\text {th }}$ or $4^{\text {th }}$ instar larvae of Tenebrio molitor $\mathrm{L}$. (Coleoptera: Tenerionidae) from a stock rearing in the laboratory (LPCMI ESALQ/USP) were transferred to the surface of the soil in plastic pots. Soil samples 
were moistened with sterile distilled water using a manual spray whenever deemed necessary.

The pots were stored in a climatic chamber at $25 \pm 1{ }^{\circ} \mathrm{C}, 70 \pm 10 \%$ in darkness and each container was turned up-side down every day during the first week to induce the movement of the larvae through the soil. From the $5^{\text {th }}$ day onwards, inspections of dead larvae were made every three days for a period of three weeks. Dead larvae were surface sterilized by immersion in sodium hypochlorite $2 \%$ for $30 \mathrm{~s}$ to prevent the growth of external contaminant saprophytic fungi, and washed three times in sterile distilled water and then individually placed in 24 cell well culture plates with a lid on. Moistened cotton with sterile distilled water were added to ensure conditions of high relative humidity. After observation of external fungal growth on the insect cadavers, pure Metarhizium colonies were obtained by streaking small quantities of conidia using platinum sterile loops in PDA medium plates (INGLIS et al., 2012).

\subsubsection{Isolation from strawberry rhizospheres}

For the isolation of the fungi from the rhizosphere, the roots were first shaken manually to remove loose soil. Roots were then washed with sterile distilled water and manually cut using laboratory scissors into small pieces $(\approx 0.5 \mathrm{~cm})$. Ten grams of root cuttings were placed together in $20 \mathrm{~mL}$ of distilled water plus $0.05 \%$ Tween 80 in a $40 \mathrm{~mL}$ flat bottom glass tube. The tubes were vortexed for $10 \mathrm{~min}$ and $100 \mu \mathrm{L}$ of this solution was serially diluted $\left(10^{-1}, 10^{-2}, 10^{-3}\right)$ and $0.1 \mathrm{~mL}$ of each dilution were plated in duplicate plates on selective media as described above (WYREBEK et al., 2011). After seven days, Metarhizium colonies were identified by the analysis of morphological characteristics and the number of CFU's per gram of humid roots was calculated. Metarhizium isolates with different colony morphology from each sample and each isolation method were cryopreserved in the Collection of Entomopathogenic Microorganisms of LPCMI-ESALQ-USP and included in the studies described below. The identities of Metarhizium colonies were confirmed based on colony morphology and characteristics of hyphae, phialides, conidiophores and conidia using a microscope (x400) and an identification key (HUMBER, 2012).

\subsection{Statistical analyses}

CFU counts of Metarhizium spp. in each plot were analyzed by fitting a linear mixed model to the proportion of Metarhizium CFU data with a full interaction 
between sample dates and plot treatment with a linear predictor, including random intercepts and slopes for each plot. Sub-models were tested using likelihood-ratio (LR) tests (MCCULLAGH; NELDER, 1989).

The proportions of $T$. molitor larvae killed by Metarhizium in soil samples were analyzed by fitting a binomial generalized linear mixed model with a full interaction between sampling time points and treatment linear predictor and including random intercepts and slopes for each plot, as well as an observation-level random effect to model overdispersion. Submodels were tested using Likelihood-Ratio (LR) tests (DEMÉTRIO et al., 2014). All analyses were performed using the $R$ statistical software environment (R DEVELOPMENT CORE TEAM, 2015)

\subsection{Molecular identification}

\subsubsection{DNA extraction}

DNA was extracted using ABI PrepMan Ultra protocol as described by Kepler et al. (2014). DNA was extracted from vegetative hyphae and conidia grown 510 days on sterile filter paper strips overlaid on PDA plates. Mycelium and conidia were transferred to a $2 \mathrm{~mL}$ sterile tube containing $300 \mathrm{~mL}$ Prepman extraction buffer and zirconia-silica beads. Cells were disrupted in a FastPrep-2 5G Instrument (MP Biomedicals) with two $10 \mathrm{~s}$ cycles at a speed setting of 5.5. The tubes were incubated in boiling water for $10 \mathrm{~min}$ and subsequently centrifuged for $10 \mathrm{~min}$ at $14,000 \mathrm{~g}$. One hundred and seventy-five $\mu \mathrm{L}$ of the supernatant were transferred to a fresh tube and stored at $-20^{\circ} \mathrm{C}$.

\subsubsection{Gene sequencing and SSR marker analyses}

SSR marker analyses were performed as described by Mayerhofer et al. (2015) using 11 markers: Ma307, Ma145, Ma165, Ma416, Ma2097, Ma164, Ma2098, Ma2065, Ma2089, Ma2063, Ma2054, (ENKERLI et al., 2005; OULEVEY et al., 2009). SSR loci were PCR amplified as described by Mayerhofer et al. (2015) and products analyzed on an ABI Prism 3130xI genetic analyzer (Applied Biosystems, Foster City, $\mathrm{CA}$ ). Fragment sizes (allele sizes) were determined using the GenMarker v1.51 (SoftGenetics LLC, State College, PA) software and GeneScan ROX400 (Applied Biosystems) as internal size standard. SSR data were analyzed using GenAlEx 6.5 (PEAKALL, 2006, 2012). 
Individual multilocus SSR haplotypes were assigned to species by sequencing the nuclear encoded translation elongation factor 1-alpha (5'-TEF1- $\alpha$ ) (BISCHOFF et al., 2009) and a nuclear intergenic marker MzFG543igs (KEPLER; REHNER, 2013). PCR amplifications were performed for one representative isolate of each SSR haplotype with primers EF2F (5'-GGAGGACAAGACTCACATCAACG- 3') and EFjR (5'-TGYTCNCGRGTYTGNCCRTCYTT-3') and MzFG543igs_1F (5'-ATTCATTCAGAACGCCTCCAA-3') and MzFG543igs_4R (5'-GGTTGCGACTGAGAATCCATG-3'). PCR products were purified using the geneMAG-PCR Kit (Chemicell, Germany) and sequenced. Sequencing was performed by Beckman Coulter Genomics (United Kingdom).

Sequences were edited and aligned with 17 reference sequences obtained from GenBank, representing ex-type cultures or taxonomically confirmed isolates of $M$. anisopliae, M. brunneum, M. guizhouense, M. lepidiotae, M. pingshaense and $M$. robertisii, (BISCHOFF et al., 2009; STEINWENDER et al., 2014; REZENDE et al., 2015) using MAFFT with the FFT-NS-i alignment option in Geneious 7.1.8. software (KEARSE et al., 2012). The sequence of M. lepidiotae (ARSEF7412) was included as outgroup and jModelTest 2.1.7 (DARRIBA et al., 2012) was used to calculate the evolution model for the phylogenetic tree (best-fit models of nucleotide substitution). The most parsimonious tree was calculated based on Bayesian (GTR-GAMMA) and Maximum Likelihood (GTR-GAMMA) model parameters using 1000 bootstrap replicates with the software Geneious 7.1.8 (KEARSE et al., 2012) of the combined single gene alignments (5'-TEF1- $\alpha$ and MzFG543igs) made in the software Mesquite 3.04 (MADDISON; MADDISON., 2015).

\subsection{Results}

\subsubsection{Isolation of entomopathogenic fungi}

\subsubsection{Selective agar media}

No significant differences were found between the densities of Metarhizium spp. in soil of the different treatments (soil from strawberry plots inoculated with $M$. anisopliae or $M$. robertsii, uninoculated control plots and margin crop area) at each sampling time point, except for September $2012\left(3.5 \pm 1.0 \times 10^{3} \mathrm{CFU} / \mathrm{g}\right)$ where the concentration in the $M$. robertsii treatment was lower than the concentration in the other 
treatments $(L R=18.35$, d.f. $=9, p=0.0313$ ) (Figure 2.1). The abundance of Metarhizium spp. in soil, within each treatment over time, differed only in plots where M. robertsii and $M$. anisopliae were applied. The highest concentrations in these treatments were observed in August $2013\left(1.4 \pm 0.6 \times 10^{4} \mathrm{CFU} / \mathrm{g}\right)$ and September $2012\left(7.5 \pm 1.2 \times 10^{3}\right.$ $\mathrm{CFU} / \mathrm{g}$ ), respectively, indicating that the application of $M$. robertsii and $M$. anisopliae did not cause an overall increase of Metarhizium density in the soil.

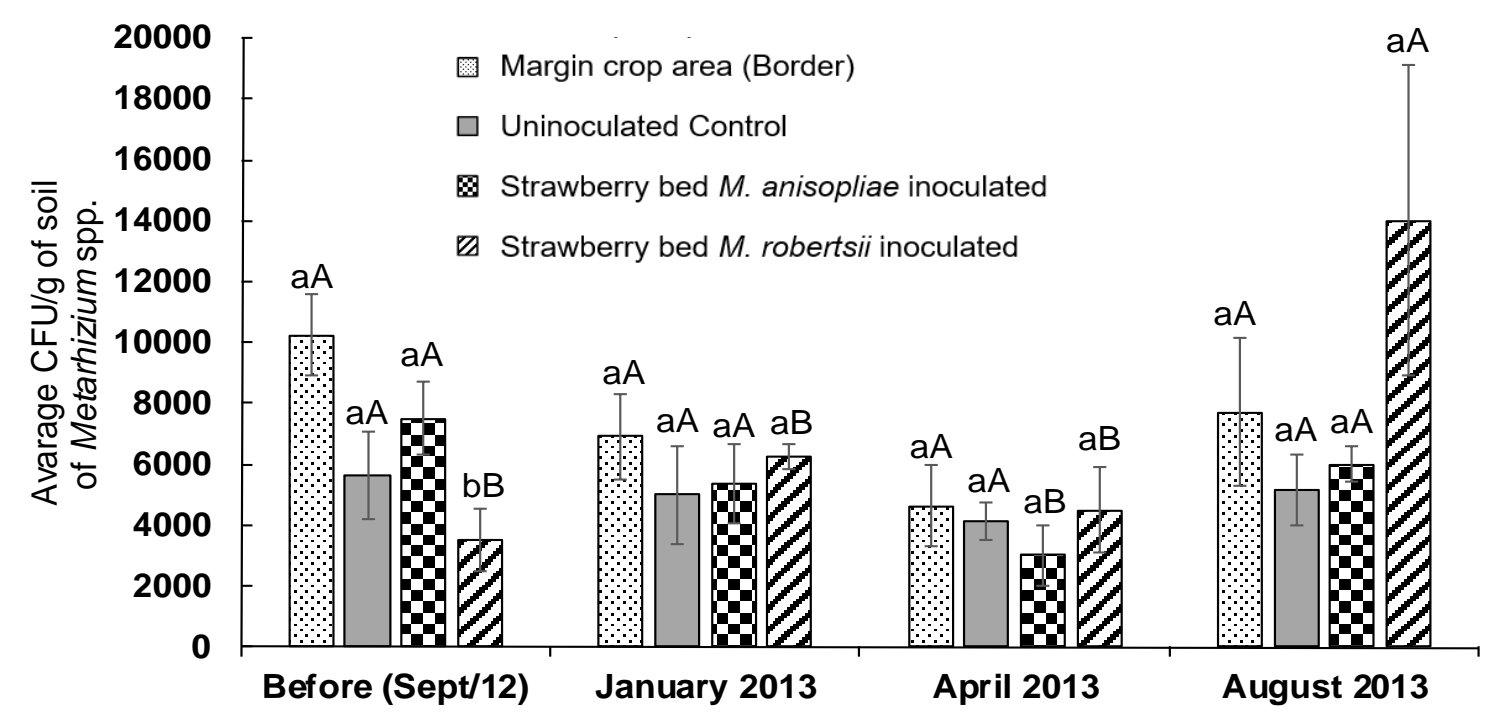

Figure 2.1 - Density [Colony forming units (CFU) per gram of humid soil] of Metarhizium spp. in strawberry crop soil. Different lower-case letters indicate differences among treatments at the same date; different upper-case letters indicate treatment differences at different dates both using linear mixed models and with a full interaction between sampling time point and treatment as the linear predictor $(P \leq 0.05)$

\subsubsection{Insect bait mortality}

The percentages of $T$. molitor larvae killed by Metarhizium spp. exposed to different soil samples were not significantly different among treatments, except in August 2013, when the values were higher in $M$. anisopliae treated plots $(77.5 \pm 6.3 \%)$ than all other treatments $(L R=1.50$, d.f. $=3, p=0.6813)$. The effect of sampling time points was significant $(L R=28.70$, d.f. $=1, p<0.0001)$.

The larval mortality proportion in the soil samples increased in those strawberry plots inoculated with $M$. anisopliae or $M$. robertsii, as well as uninoculated control plots after August 2013, January 2013 and April 2013 compared to the previous sample dates, respectively. At the last sampling, the percentage of larvae killed by Metarhizium 
were $50.0 \pm 15.8 \%, 45.0 \pm 6.5 \%$ and $36.0 \pm 12.1 \%$ in treatment plots inoculated with M. robertsii, uninoculated control and border plants, respectively (Figure 2.2).

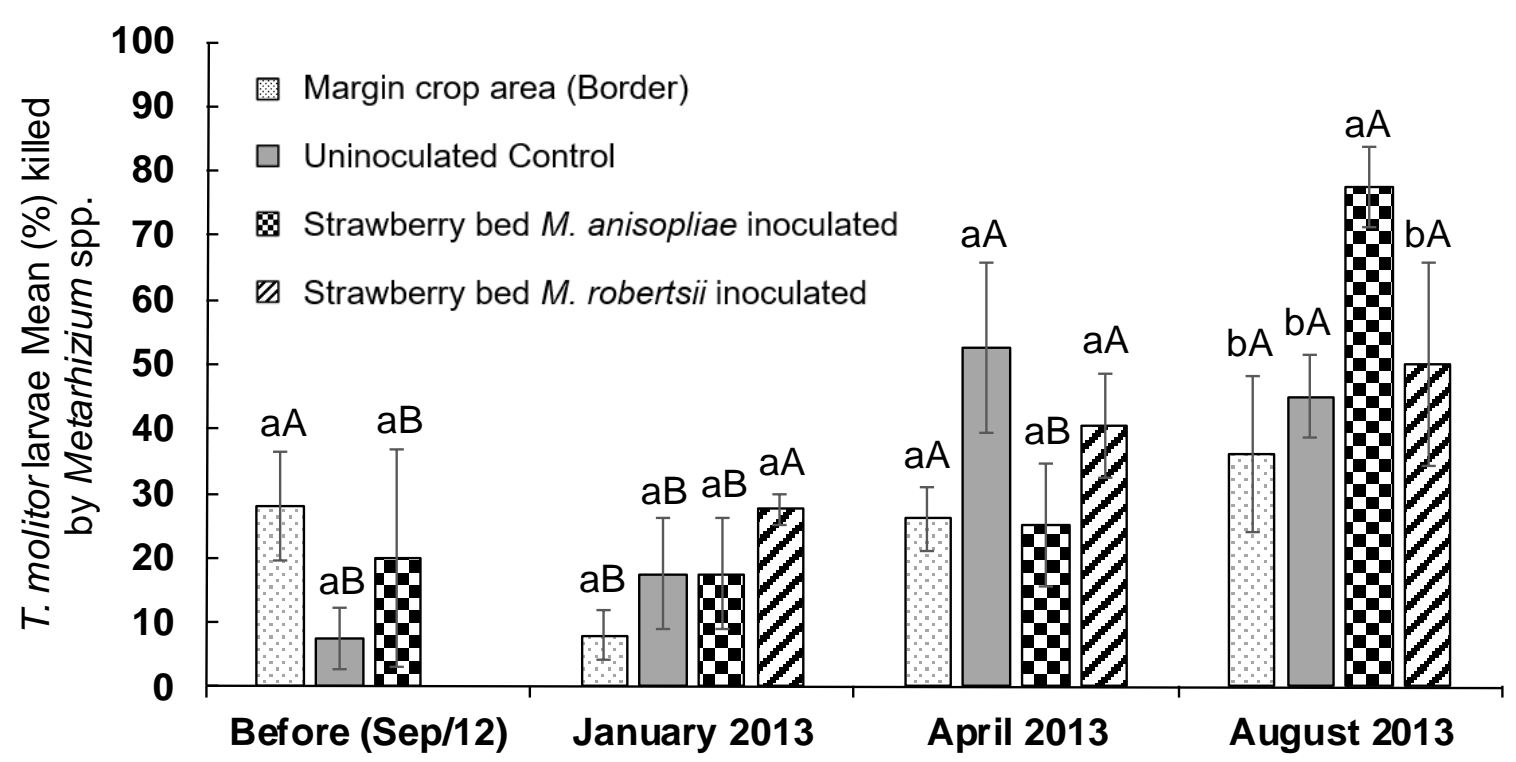

Figure 2.2 - Mortality (Mean \pm SE) of Tenebrio molitor larvae used in the isolation of Metarhizium spp. by the insect bait method. Different lower-case letters indicate differences among treatments at the same date; different uppercase letters indicate treatment differences at different dates both using binomial generalized linear mixed models and with a full interaction between sampling time point and treatment as the linear predictor $(P \leq$ 0.001)

\subsubsection{Gene sequencing and SSR marker analyses}

Of the 108 isolates recovered from all the plots during the period of the experiment and used in the SSR marker analyses: $27.8 \%$ were found in the margins of the crop associated with the border herb plants, $25.0 \%$ were found in the uninoculated control plots, $20.4 \%$ were in $M$. anisopliae treated plots, $16.7 \%$ were from the $M$. robertsii treated plots, 5.5\% were recovered from rhizosphere in $M$. robertsii treated plots and $4.6 \%$ were from rhizosphere in $M$. anisopliae treated plots (Table 2.1). These 108 isolates were used in the SSR analyses. All loci displayed polymorphism. The analysis resolved 11 haplotypes among them (Table 2.2). 
Table 2.1 - Occurrence of each Metarhizium haplotype in strawberry crop soil before the application and at three subsequent sampling time points. ( $M a=$ Metarhizium anisopliae, $M r=M$. robertsii, $M b=M$. brunneum and $M p=M$. pingshaense)

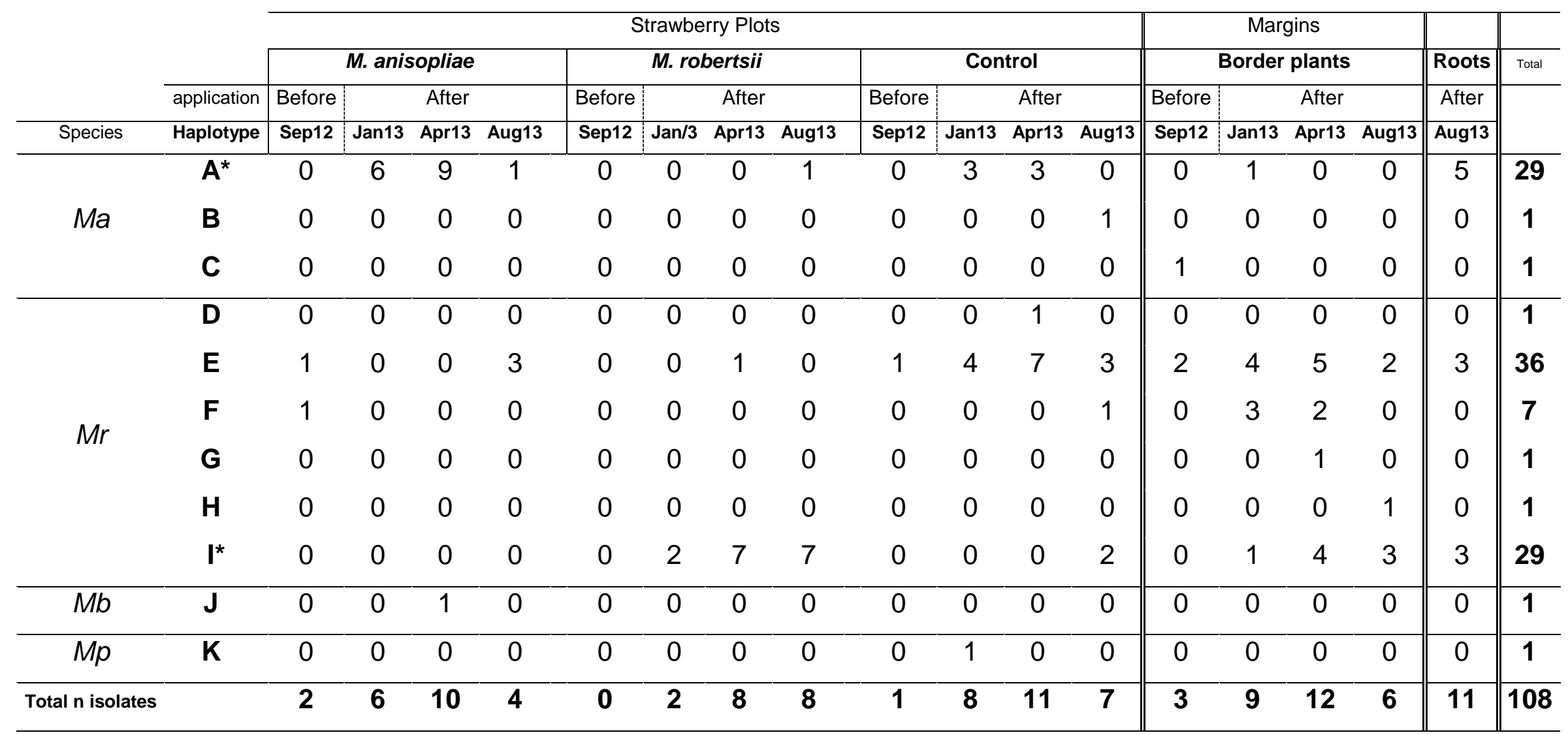

${ }^{\star}$ haplotype of applied isolates (M. anisopliae - ESALQ1037 and M. robertsii - ESALQ1426) 
Table 2.2 - Number of alleles, allele size range [base pairs] for 11 SSR loci for each of the eleven haplotypes identified with DNA sequence based analyses

\begin{tabular}{cccc}
\hline Locus & $\begin{array}{c}\text { M. brunneum } \mathrm{n}=1 \text { and } \\
\text { M. pingshaense } \mathrm{n}=1\end{array}$ & M. anisopliae $\mathrm{n}=22$ & M. robertsii $\mathrm{n}=84$ \\
\hline Ma145 & $1[106]$ & $1[106]$ & $2[107 ; 108]$ \\
Ma164 & $2[116 ; 121]$ & $1[116]$ & $2[116 ; 117]$ \\
Ma165 & $2[140 ; 141]$ & $2[140 ; 141]$ & $1[143]$ \\
Ma307 & $2[112 ; 161]$ & $2[161 ; 164]$ & $3[149-161]$ \\
Ma416 & $2[115 ; 116]$ & $1[115]$ & $1[126]$ \\
Ma2054 & $2[218 ; 238]$ & $1[218]$ & $2[217 ; 220]$ \\
Ma2063 & $2[144 ; 143]$ & $2[144 ; 146]$ & $1[137]$ \\
Ma2065 & $2[131 ; 146]$ & $1[131]$ & $2[129 ; 131]$ \\
Ma2089 & $2[196 ; 199]$ & $2[196 ; 198]$ & $1[194]$ \\
Ma2097 & $2[189 ; 191]$ & $2[191 ; 195]$ & $3[181-185]$ \\
Ma2098 & $2[171 ; 179]$ & $1[171]$ & $3[171-197]$ \\
\hline Number of & $2(\mathrm{~J}, \mathrm{~K})$ & $3\left(\mathrm{~A}^{*}-\mathrm{C}\right)$ & $6\left(\mathrm{D}-\mathrm{I}^{*}\right)$ \\
haplotypes & & &
\end{tabular}

haplotype of applied isolates ( $M$. anisopliae - ESALQ1037 and $M$. robertsii ESALQ1426)

A species assignment based on 5'TEF1- $\alpha$ and MzFG543igs sequence analyses was performed with all different haplotypes. Sequence alignments and subsequent phylogenetic analyses revealed the presence of four Metarhizium species clustering with $M$. anisopliae, $M$. robertsii, $M$. brunneum and $M$. pingshaense reference isolates (Figure 2.3). Sequence alignments consisted of 625 positions for 5'TEF1- $\alpha$ and 911 position for MzFG543igs and after combining them, sequence differences were compared in an alignment of 1,210 positions of 5'TEF1- $\alpha$ and MzFG543igs concatenated dataset (Table 2.3). Here, M. robertsii intraspecific differences ranged between one up to 53 positions while lower intraspecific variation was observed within $M$. anisopliae, maximum of 6 base pair differences. Base pair differences between $M$. robertsii and M. brunneum haplotypes ranged from 158 to 193 positions, representing the largest differences found among the haplotypes studied. The forth species recovered was $M$. pingshaense, with a difference ranging between 41 positions ( $M$. robertsii) to 161 positions (M. brunneum). 
Table 2.3 - Base pair difference among the 11 Metarhizium haplotypes in sequences of the $5^{\prime}$ end of Elongation Factor 1- $\alpha$ and MzFG543igs concatenated dataset (total positions 1,210 bp). (Ma = Metarhzium anisopliae, $M r=M$. robertsii, $M b=M$. brunneum and $M p=M$. pingshaense)

\begin{tabular}{ccccccccccccc}
\hline Species & & $M a$ & $M a$ & $M a$ & $M p$ & $M r$ & $M r$ & $M r$ & $M r$ & $M r$ & $M r$ & $M b$ \\
\hline & Haplotype & $\mathbf{A}^{*}$ & $\mathbf{C}$ & $\mathbf{B}$ & $\mathbf{K}$ & $\mathbf{D}$ & $\mathbf{E}$ & $\mathbf{I}^{*}$ & $\mathbf{F}$ & $\mathbf{G}$ & $\mathbf{H}$ & $\mathbf{J}$ \\
\hline \hline$M a$ & $\mathbf{A}^{*}$ & & & & & & & & & & & \\
$M a$ & $\mathbf{C}$ & 6 & & & & & & & & & & \\
$M a$ & $\mathbf{B}$ & 5 & 1 & & & & & & & & \\
$M p$ & $\mathbf{K}$ & 46 & 40 & 41 & & & & & & & & \\
$M r$ & $\mathbf{D}$ & 66 & 60 & 61 & 53 & & & & & & & \\
$M r$ & $\mathbf{E}$ & 89 & 89 & 90 & 82 & 49 & & & & & \\
$M r$ & $\mathbf{I}^{*}$ & 56 & 50 & 51 & 43 & 10 & 39 & & & & & \\
$M r$ & $\mathbf{F}$ & 90 & 90 & 91 & 83 & 50 & 1 & 40 & & & \\
$M r$ & $\mathbf{G}$ & 63 & 57 & 58 & 50 & 5 & 52 & 13 & 53 & & & \\
$M r$ & $\mathbf{H}$ & 54 & 48 & 49 & 41 & 14 & 43 & 4 & 44 & 13 & & \\
$M b$ & $\mathbf{J}$ & 159 & 163 & 164 & 161 & 170 & 192 & 160 & 193 & 167 & 158 & \\
\hline \hline
\end{tabular}

Three haplotypes were found among the $22 \mathrm{M}$. anisopliae isolates, and were referred to as haplotypes A (including applied ESALQ1037), B and C; six haplotypes among $84 M$. robertsii isolates: D, E, F, G, H and I (including applied ESALQ1426); and the single isolates of $M$. brunneum and $M$. pingshaense were referred to haplotypes $\mathrm{J}$ and $\mathrm{K}$, respectively (Figure 2.3). 


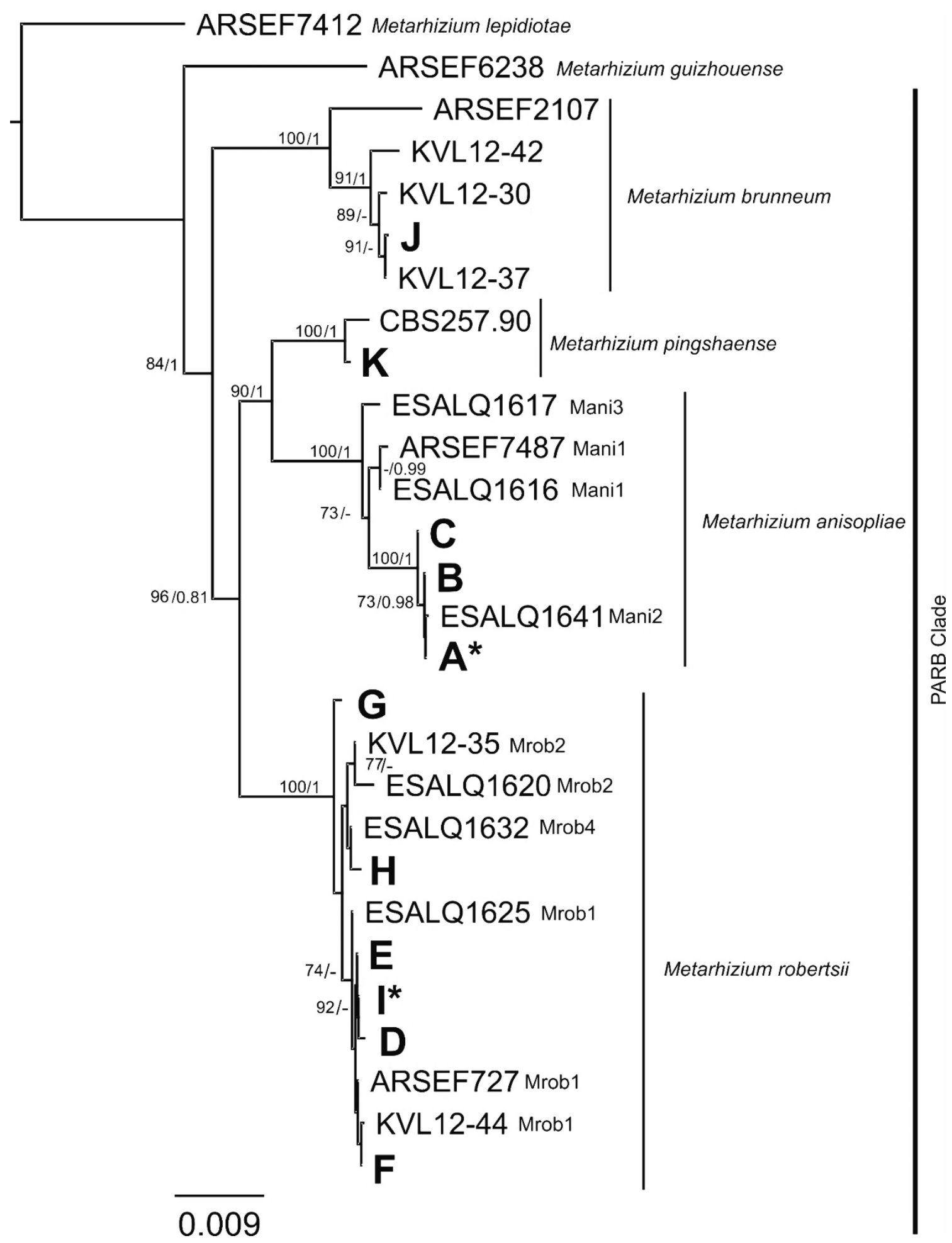

Figure 2.3 - (ML) Maximum likelihood (GTR-gamma) / (B) Bayesian (GTR-gamma) phylogeny of the combined data set of $5^{\circ}$ TEF and MzFG543igs sequences of 11 haplotypes identified in the experiment crop, including 17 taxonomically validated reference strains accessioned in ARSEF (ARS Entomopathogenic Fungal Culture Collection, CBS (Fungal Biodiversity Centre) and ESALQ (Collection of Entomopathogenic Microorganisms of LPCMI-ESALQ-USP). Bootstrap support values $\geq$ $70 \%$ are listed near nodes of each type of analyses (ML/B) 


\subsubsection{Species and haplotype frequencies}

Three of the haplotypes, two assigned to $M$. robertsii $(\mathrm{E}, \mathrm{I})$ and one assigned to M. anisopliae (A, the applied isolate) were most frequently isolated. $M$. robertsii was the most frequent species comprising $77.8 \%$ of all isolates, followed by $20.4 \%$ of $M$. anisopliae, and one isolate each of $M$. brunneum and $M$. pingshaense. Among the $M$. robertsii haplotypes two were most frequent; haplotype E (33.3\% of the Metarhizium spp. isolates) an indigenous haplotype and I (26.8\%) the haplotype of the applied $M$. robertsii isolate. Among the $M$. anisopliae, haplotype A, representing the applied isolate, was most frequent (26.8\%). Except for the M. robertsii haplotype $\mathrm{F}(6.5 \%)$ all remaining haplotypes were represented by single isolates only (Table 2.4). The most frequent haplotype $E(M$. robertsii) was detected in all the treatments. The haplotypes (A and I) of the applied isolates were not detected in any of the treatments before application (Table 2.1).

Of the three most frequently isolated haplotypes, two were assigned to $M$. robertsii $(\mathrm{E}, \mathrm{I})$ and one assigned to $M$. anisopliae (A, the applied isolate). $M$. robertsii was the most frequent species comprising $77.8 \%$ of all isolates, followed by $20.4 \%$ for M. anisopliae, and a single isolate for both M. brunneum and M. pingshaense. Among the $M$. robertsii haplotypes; haplotype E (33.3\% of the Metarhizium spp. isolates) - an indigenous haplotype and I (26.8\%) - the haplotype of the applied M. robertsii isolate, were the most frequently isolated. Among the $M$. anisopliae, haplotype A, representing the applied isolate, was most frequent (26.8\%). Except for the $M$. robertsii haplotype $F$ (6.5\%), all remaining haplotypes were represented by single isolates only (Table 2.4). The most frequent haplotype $\mathrm{E}(M$. robertsii) was detected in all the treatments. The haplotypes ( $\mathrm{A}$ and $\mathrm{I}$ ) of the applied isolates were not detected in any of the treatments before application (Table 2.1).

The two applied Metarhizium isolates (haplotype A and I) were recovered in several samples in the plots from which they were inoculated, as well as a number of plots from which they were not. The inoculated $M$. anisopliae haplotype A was found after four months of inoculation in all treatments except in $M$. robertsii treated plots; in this latter treatment the applied haplotype A was found after one year. The inoculated M. robertsii haplotype I was detected after four months in the plots where it was applied and in the soil around border plants. After one year (August, 2013) this haplotype was also detected in the uninoculated control plots while it was never recovered in the $M$. 
anisopliae treated plots. The number of haplotypes detected after the inoculation (not including haplotypes of the inoculated isolates) was lower in the M. robertsii $(\mathrm{n}=1)$ and M. anisopliae $(n=2)$ treated plots than in the uninoculated control plots $(n=5)$ and around border plants $(n=4)$. More M. robertsii isolates $(n=22)$ where obtained the last sample occasion than $M$. anisopliae isolates $(n=3)$.

Table 2.4 - Allele of sizes of 11 SSR markers of all haplotype found at the strawberry field studied

\begin{tabular}{|c|c|c|c|c|c|c|c|c|c|c|c|c|}
\hline \multirow[b]{2}{*}{ HAPLO } & \multicolumn{11}{|c|}{ SSR Markers } & \multirow{3}{*}{$\begin{array}{c}\text { Num } \\
\text { ber }\end{array}$} \\
\hline & Ma & Ma & Ma & Ma & Ma & Ma & Ma & $\mathbf{M a}$ & $\mathrm{Ma}$ & Ma & $\mathrm{Ma}$ & \\
\hline TYPE & 307 & 145 & 165 & 416 & 2097 & 164 & 2098 & 2065 & 2089 & 2063 & 2054 & \\
\hline$A$ & 164 & 106 & 140 & 115 & 191 & 116 & 171 & 131 & 198 & 146 & 218 & 29 \\
\hline B & 164 & 106 & 140 & 115 & 195 & 116 & 171 & 131 & 198 & 144 & 218 & 1 \\
\hline C & 161 & 106 & 141 & 115 & 191 & 116 & 171 & 131 & 196 & 144 & 218 & 1 \\
\hline D & 161 & 108 & 143 & 126 & 183 & 117 & 197 & 131 & 196 & 137 & 217 & 1 \\
\hline E & 161 & 108 & 143 & 126 & 183 & 117 & 197 & 131 & 194 & 137 & 217 & 36 \\
\hline $\mathrm{F}$ & 161 & 108 & 143 & 126 & 183 & 117 & 171 & 131 & 194 & 137 & 217 & 7 \\
\hline G & 161 & 108 & 143 & 126 & 183 & 117 & 171 & 131 & 194 & 137 & 253 & 1 \\
\hline $\mathrm{H}$ & 149 & 107 & 143 & 126 & 181 & 117 & 183 & 129 & 194 & 137 & 220 & 1 \\
\hline 1 & 152 & 108 & 143 & 126 & 185 & 117 & 195 & 129 & 194 & 137 & 217 & 29 \\
\hline$J$ & 112 & 0 & 140 & 116 & 189 & 121 & 179 & 146 & 199 & 143 & 238 & 1 \\
\hline K & 148 & 103 & 139 & 126 & 183 & 122 & 174 & 127 & 194 & 154 & 226 & 1 \\
\hline
\end{tabular}

Three haplotypes of $M$. anisopliae and $M$. robertsii were recovered from the rhizosphere samples. Besides the inoculated isolates (haplotype $A$ and I), only the most common indigenous isolate in the soil (M. robertsii haplotype $E$ ) was found from the rhizosphere (Table 2.1).

The haplotype frequency of the applied $M$. robertsii isolate (I) increased from zero- before inoculation- to $0.12,0.29$ and 0.40 , after 4,8 and 12 months, respectively. The haplotype frequency of the applied $M$. anisopliae isolate (A) increased 4 months after application to 0.40 but decreased after 8 and 12 months to 0.29 and 0.20 , respectively. The haplotype frequency of most common indigenous isolate (haplotype E) - before the inoculation of the treatments- was 0.67 and decrease to 0.32 after 4 
months. The frequency of this haplotype was stable after this period (0.31 and 0.31 after 8 and 12 months).

\subsection{Discussion}

In this study, we demonstrate that two Metarhizium isolates applied in the strawberry field showed persistence and dispersion in the soil and colonized the rhizosphere. The inclusion of SSR markers allowed for a reliable and transparent identification of the applied fungal isolates among the indigenous Metarhizium haplotypes. The applied isolates were recovered most frequently in their specific treatment for up to one year after application, but they were also found in uninoculated strawberry control plots and in soil of field margins. A high frequency of haplotypes of $M$. robertsii was recovered across all plots compared to other Metarhizium species. In addition, the occurrence of the $M$. robertsii in the uninoculated plots (control and border plants) was higher than of other Metarhizium spp. indicating that this species is the most naturally abundant at the field site and may be better adapted to the prevailing conditions. Regarding the final sampling occasion, the inoculated $M$. anisopliae isolate comprised only $25 \%$ of the haplotypes found in the plots in which it was applied, and the $M$. robertsii isolate comprised $87.5 \%$ of the haplotypes found in the plots in which it was applied. Our results support the hypothesis raised by Rezende et al. (2015) that Brazilian M. robertsii haplotypes may be better adapted to persistence in the soil environment as opposed to being an entomopathogen- above ground. The inoculated M. robertsii isolate ESALQ1426 was originally obtained from soil and it seems to persist better than the M. anisopliae isolate ESALQ1037 which was isolated from a fire ant. So far, most characterized isolates originating from insect hosts in Brazil belong to the M. anisopliae Mani2 clade (REZENDE et al., 2015), including the inoculated isolate ESALQ1037 of the present study. The seemingly primarily soil-based ecology of $M$. robertsii including the indication of an association with plant roots reported here is consistent with other studies (BEHIE et al., 2012; STEINWENDER et al., 2015). We suggest that additional studies using microsatellites should be initiated to understand the primarily above-ground ecology of $M$. anisopliae in Brazil.

The $M$. anisopliae isolate applied in the soil was recovered from the rhizosphere of the strawberry plants at the final sampling occasion one year after application, indicating that a member of Mani2 clade can be associated with roots. Rhizosphere 
soils are a potential reservoir for Metarhizium spp.- being the soil/root interphase where plants, insects, and microbes interact (HU; ST. LEGER, 2002). Persistence of $M$. brunneum in the strawberry rhizospheres has been shown to depend on local adaptations to the prevailing abiotic conditions at the field site (KLINGEN et al., 2015), and rhizosphere compatibility of $M$. anisopliae in Brazil could be an important trait of a biocontrol agent for long term persistence and prolonged biocontrol efficacy.

Our study is the first in Brazil to implement SSR markers, and therefore we got much more accurate data, detailing the natural occurrence of individual isolates, focusing on within species diversity and persistence over time of each specific applied isolate in different crops. Comparison with earlier studies (from Brazil and elsewhere) should take this into account. Vieira Tiago et al. (2012) studied the persistence of $M$. anisopliae in sugarcane soil, but in laboratory conditions (soil brought from field and used in pots) and detected the fungus for up to 60 days. The extrapolation of these laboratory data into a field situation is, however, difficult. A high persistence of $M$. bruneum isolate Bipesco 5 and M. anisopliae s.l. isolate 2277 in corn field soil in Hungary, reaching up to 15 months, was demonstrated by Pilz et al. (2011) using some of the same SSR markers as in the present study. These data corroborate our findings regarding the long-term persistence of inoculated Metarhizium isolates.

Although the treatment plots had a greater abundance of the specific isolates which were applied, and there was a number of cases in which the treatment isolates dispersed into neighboring control plots, there was high degree of diversity of indigenous haplotypes were still found in all plots. It therefore appears that the application of biocontrol fungal isolates did not significantly alter the Metarhizium community composition within the one-year time frame of this study. Earlier studies have also reported high diversity of Metarhizium species in Brazil. Lopes, Mesquita et al. (2013) found in small agricultural habitats (commercial banana fields) M. anisopliae, M. pingshaense and what is likely to be an undescribed Metarhizium species. Lopes, Souza et al. (2013) further found $M$. lepidiotae infecting a Melonthid species in maize crop, and M. brunneum infecting a hemipteran species in south Brazil (LOPES et al., 2014). Rocha et al. (2013), studying the Metarhizium diversity of soils in central Brazil found a large number of isolates of $M$. anisopliae, M. robertsii and M. pemphigi. Rezende et al. (2015) focused on the Metarhizium diversity associated with sugarcane agriculture and identified two new taxonomically unassigned linages besides the ones found in the studies above. In the present study we recovered the most commonly 
reported Metarhizium species of Brazil, $M$. robertsii and $M$. anisopliae, also to occur in strawberry field soil as well as the seemingly less abundant species of Brazil: $M$. brunneum and $M$. pingshaense.

Besides the two applied Metarhizium isolates, we identified five indigenous haplotypes in the strawberry field margins and the control plots, indicating that the strawberry cultivation regimes did not negatively affect fungal diversity directly. High Metarhizium densities were found in soil samples collected in agriculture sites in Switzerland from low-input permanent grassland and improved field margins compared to arable, intensively cultivated fields, indicating that both semi-natural habitat types may provide potential refuges for Metarhizium species (SCHNEIDER et al., 2012). Clifton et al. (2015) proposed that the abundance of $M$. anisopliae s.l. in field margins was negatively affected by proximity to conventional fields, suggesting that cropping practices within a field could affect soil-borne microorganisms outside of a field. In our study, the margin and border plants presented comparable abundance and diversity of Metarhizium spp. to uninoculated control plots. The lack of chemical control measures in the experimental strawberry fields could have been an important contributor to this observation, but more studies are needed to evaluate potential short term and long term negative effects of agro-chemicals on the Metarhizium community.

The persistence and dispersal of $M$. anisopliae and M. robertsii applied through soil drenching in strawberry soils demonstrated in this study provides valuable information regarding predictions and efficacy of biocontrol agents in the field. Further studies are needed to evaluate if rhizosphere colonization indicated in the present study, are beneficial to plant growth promotion (SASAN; BIDOCHKA, 2012) whilst being antagonistic towards pests and diseases (SASAN; BIDOCHKA, 2013) as has been seen in laboratory settings for other crops.

\section{Acknowledgments}

The authors are grateful to Louise Lee Munk Larsen, Lívia Maria Alves Porto, Giovani Marcio Coura Junior, Pamella Gusmão de Góes Brennand, Jeronymo Dalapicolla, Alessandro Alves-Pereira and Vinnie Deichmann for their technical assistance and Prof. Luiz Carlos Dias Rocha and all collaborators from the Instituto Federal do Sul de Minas (Inconfidentes-MG). We also thank Jacob Daniel Charters (University of Queensland) for the kind English revision. This research was funded by 
the Danish Agency for Science, Technology and Innovation and The São Paulo Research Foundation (through the project IMBICONT: 'Improved biological control for IPM in fruits and berries', project number 0603-00486B and 2011/51556-3 respectively). The first author is a recipient of scholarships from the São Paulo Research Foundation (FAPESP, project number 2013/24430-4 and 2013/10517-0).

\section{References}

AGRA-FNP-PESQUISAS. AGRIANUAL: anuário estatístico da agricultura brasileira. São Paulo: FNP: Consultoria ; Agroinformativos, 2015. 504 p.

BEHIE, S.W.; BIDOCHKA, M.J. Ubiquity of insect-derived nitrogen transfer to plants by endophytic insect-pathogenic fungi: an additional branch of the soil nitrogen cycle. Applied and Environmental Microbiology, Washington, v. 80, n. 5, p. 1553-1560, 2014.

BEHIE, S.W.; ZELISKO, P.M.; BIDOCHKA, M.J. Endophytic insect-parasitic fungi translocate nitrogen directly from insects to plants. Science, Washington, v. 336, n. 6088, p. 1576-1577, 2012.

BISCHOFF, J.F.; REHNER, S.A.; HUMBER, R.A. A multilocus phylogeny of the Metarhizium anisopliae lineage. Mycologia, New York, v. 101, n. 4, p. 512-530, 2009.

CLIFTON, E.H.; JARONSKI, S.T.; HODGSON, E.W.; GASSMANN, A.J. Abundance of soil-borne entomopathogenic fungi in organic and conventional fields in the midwestern USA with an emphasis on the effect of herbicides and fungicides on fungal persistence. PLoS One, San Francisco, v. 10, e0133613, 2015.

D'ALESSANDRO, C.P.; PADIN, S.; URRUTIA, M.I.; LÓPEZ LASTRA, C.C. Interaction of fungicides with the entomopathogenic fungus Isaria fumosorosea. Biocontrol Science and Technology, Dordrecht, v. 21, n. 2, p. 189-197, 2011.

DARRIBA, D.; TABOADA, G.L.; DOALLO, R.; POSADA, D. jModelTest 2: more models, new heuristics and parallel computing. Nature Methods, New York, v. 9, n. 8, p. 772, 2012.

ENKERLI, J.; KÖLLIKER, R.; KELLER, S.; WIDMER, F. Isolation and characterization of microsatellite markers from the entomopathogenic fungus Metarhizium anisopliae. Molecular Ecology Notes, Oxford, v. 5, n. 2, p. 384-386, 2005.

FAO. FAOSTAT. Disponível em: <http://faostat3.fao.org/>. Acesso em: 21 Jan. 2016. 
FERNANDES, É.K.K.; KEYSER, C.A.; RANGEL, D.E.N.; FOSTER, R.N.; ROBERTS, D.W. CTC medium: a novel dodine-free selective medium for isolating entomopathogenic fungi, especially Metarhizium acridum, from soil. Biological Control, Orlando, v. 54, n. 3, p. 197-205, 2010.

HU, G.; ST. LEGER, R.J. Field studies using a recombinant mycoinsecticide (Metarhizium anisopliae) reveal that it is rhizosphere competent. Applied and Environmental Microbiology, Washington, v. 68, n. 12, p. 6383-6387, 2002.

HUMBER, R.A. Identification of entomopathogenic fungi. In: LACEY, L.A. (Ed.). Manual of techniques in invertebrate pathology. $2^{\text {nd }}$ ed. Dordrecht: Springer, 2012. p. 151-187.

INGLIS, G.D.; ENKERLI, J.; GOETTEL, M.S. Laboratory techniques used for entomopathogenic fungi: Hypocreales. In: LACEY, L.A. (Ed.). Manual of techniques in invertebrate pathology. $2^{\text {nd }}$ ed. Dordrecht: Springer, 2012. p.189-253.

JARONSKI, S.T.; JACKSON, M.A. Mass production of entomopathogenic Hypocreales. In: LACEY, L.A. (Ed.). Manual of techniques in invertebrate pathology. $2^{\text {nd }}$ ed. Dordrecht: Springer, 2012. p. 255-284.

KEARSE, M.; MOIR, R.; WILSON, A.; STONES-HAVAS, S.; CHEUNG, M.; STURROCK, S.; BUXTON, S.; COOPER, A.; MARKOWITZ, S.; DURAN, C.; THIERER, T.; ASHTON, B.; MENTJIES, P.; DRUMMOND, A. Geneious Basic: an integrated and extendable desktop software platform for the organization and analysis of sequence data. Bioinformatics, Oxford, v. 28, n. 12, p. 1647-1649, 2012.

KEPLER, R.M.; REHNER, S.A. Genome-assisted development of nuclear intergenic sequence markers for entomopathogenic fungi of the Metarhizium anisopliae species complex. Molecular Ecology Resources, Oxford, v. 13, n. 2, p. 210-217, 2013.

KEPLER, R.M.; HUMBER, R.A.; BISCHOFF, J.F.; REHNER, S.A. Clarification of generic and species boundaries for Metarhizium and related fungi through multigene phylogenetics. Mycologia, New York, v. 106, n. 4, p. 811-829, 2014.

KEPLER, R.M.; UGINE, T.A.; MAUL, J.E.; CAVIGELLI, M.A.; REHNER, S.A. Community composition and population genetics of insect pathogenic fungi in the genus Metarhizium from soils of a long-term agricultural research system.

Environmental Microbiology, Oxford, v. 17, n. 8, p. 2791-2804, 2015.

KHAN, A.L.; HAMAYUN, M.; KHAN, S.A.; KANG, S.M.; SHINWARI, Z.K.; KAMRAN, M.; UR REHMAN, S.; KIM, J.G.; LEE, I.J. Pure culture of Metarhizium anisopliae LHL07 reprograms soybean to higher growth and mitigates salt stress. World Journal of Microbiology and Biotechnology, Oxford, v. 28, n. 4, p. 1483-1494, 2012.

KLINGEN, I.; HAUKELAND, S. The soil as a reservoir for natural enemies of pest insects and mites with emphasis on fungi and nematodes. In: EILENBERG, J.; 
HOKKANEN, H.M.T. (Ed.). An ecological and societal approach to biological control. Amsterdam: Springer, 2006. v. 2, chap. 9, p. 145-211. (Progress in Biological Control).

KLINGEN, I.; WESTRUM, K.; MEYLING, N.V. Effect of Norwegian entomopathogenic fungal isolates against Otiorhynchus sulcatus larvae at low temperatures and persistence in strawberry rhizospheres. Biological Control, Orlando, v. 81, p. 1-7, 2015.

LOPES, R.B.; SOUZA, D.A.; OLIVEIRA, C.M.; FARIA, M. Genetic diversity and pathogenicity of Metarhizium spp. associated with the white grub Phyllophaga capillata (Blanchard) (Coleoptera: Melolonthidae) in a soybean field. Neotropical Entomology, Londrina, v. 42, n. 4, p. 436-438, 2013.

LOPES, R.B.; FARIA, M.; SOUZA, D.A.; BLOCH, C. JR.; SILVA, L.P.; HUMBER, R.A. MALDI-TOF mass spectrometry applied to identifying species of insectpathogenic fungi from the Metarhizium anisopliae complex. Mycologia, New York, v. 106, n. 4, p. 865-878, 2014.

LOPES, R.B.; MESQUITA, A.L.M.; TIGANO, M.S.; SOUZA, D.A.; MARTINS, I.; FARIA, M. Diversity of indigenous Beauveria and Metarhizium spp. in a commercial banana field and their virulence toward Cosmopolites sordidus (Coleoptera:

Curculionidae). Fungal Ecology, Manchester, v. 6, n. 5, p. 356-364, 2013.

MADDISON, W. P.; MADDISON., D. R. Mesquite: a modular system for evolutionary analysis. Version 3.04 [retrived from

http://mesquiteproject.wikispaces.com/home in 24 Jan 2015] 2015.

MAREDIA, K.M. Introduction and overview. In: MAREDIA, K.M.; MOTA-SANCHEZ, D.; DAKOUO, D. (Ed.). Integrated pest management in the global arena.

Cambridge: CABI, 2003. p. 512.

MAYERHOFER, J.; LUTZ, A.; WIDMER, F.; REHNER, S.A.; LEUCHTMANN, A.; ENKERLI, J. Multiplexed microsatellite markers for seven Metarhizium species. Journal of Invertebrate Pathology, San Diego, v. 132, p. 132-4, 2015.

MCCULLAGH, P.; NELDER, J. A. Generalized linear models. New York; London: Chapman and Hall, 1989. 511 p.

MEYLING, N.V.; EILENBERG, J. Ecology of the entomopathogenic fungi Beauveria bassiana and Metarhizium anisopliae in temperate agroecosystems: potential for conservation biological control. Biological Control, Orlando, v. 43, n. 2, p. 145-155, 2007.

OLIVEIRA, D.G.; PAULI, G.; MASCARIN, G.M.; DELALIBERA, I. A protocol for determination of conidial viability of the fungal entomopathogens Beauveria bassiana and Metarhizium anisopliae from commercial products. Journal of Microbiological Methods, Amsterdam, v. 119, p. 44-52, 2015. 
OULEVEY, C.; WIDMER, F.; KÖLLIKER, R.; ENKERLI, J. An optimized microsatellite marker set for detection of Metarhizium anisopliae genotype diversity on field and regional scales. Mycological Research, Cambridge, v. 113, n. 9, p. 1016-24, 2009.

PARRA, J.R.P. Biological control in Brazil: an overview. Scientia Agricola, Piracicaba, v. 71, n. 5, p. 420-429, 2014.

PEAKALL, R.; PE, S. GENALEX 6: genetic analysis in Excel: population genetic software for teaching and research. Molecular Ecology Notes, Oxford, v. 6, p. 288295, 2006.

. GenAIEx 6.5: genetic analysis in Excel: population genetic software for teaching and research-an update. Bioinformatics, Oxford, v. 28, p. 2537-2539, 2012.

PILZ, C.; ENKERLI, J.; WEGENSTEINER, R.; KELLER, S. Establishment and persistence of the entomopathogenic fungus Metarhizium anisopliae in maize fields. Journal of Applied Entomology, Berlin, v. 135, n. 6, p. 393-403, 2011.

R DEVELOPMENT CORE TEAM. R: a language and environment for statistical computing. Vienna: R Foundation for Statistical Computing, 2015. Disponível em: <http://www.R-project.org>. Acesso em: 05 fev. 2016.

REZENDE, J.M.; ZANARDO, A.B.R.; LOPES, M.D.; DELALIBERA, I.; REHNER, S.A. Phylogenetic diversity of Brazilian Metarhizium associated with sugarcane agriculture. Biocontrol, Dordrecht, v. 60, n. 4, p. 495-505, 2015.

ROCHA, L.F.; INGLIS, P.W.; HUMBER, R.A.; KIPNIS, A.; LUZ, C. Occurrence of Metarhizium spp. in Central Brazilian soils. Journal of Basic Microbiology, Berlin, v. 53, n. 3, p. 251-259, 2013.

RUDEEN, M.L.; JARONSKI, S.T.; PETZOLD-MAXWELL, J.L.; GASSMANN, A.J. Entomopathogenic fungi in cornfields and their potential to manage larval western corn rootworm Diabrotica virgifera virgifera. Journal of Invertebrate Pathology, San Diego, v. 114, n. 3, p. 329-332, 2013.

SAMSON, P.R.; MILNER, R.J.; SANDER, E.D.; BULLARD, G.K. Effect of fungicides and insecticides applied during planting of sugarcane on viability of Metarhizium anisopliae and its efficacy against white grubs. Biocontrol, Dordrecht, v. 50, n. 1, p. 151-163, 2005.

SASAN, R.K.; BIDOCHKA, M.J. The insect-pathogenic fungus Metarhizium robertsii (Clavicipitaceae) is also an endophyte that stimulates plant root development.

American Journal of Botany, Lancaster, v. 99, n. 1, p. 101-107, 2012. 
Antagonism of the endophytic insect pathogenic fungus Metarhizium robertsii against the bean plant pathogen Fusarium solani f. sp. phaseoli. Canadian Journal of Plant Pathology, Ontario, v. 35, n. 3, p. 288-293, 2013.

SATO, M.E.; DA SILVA, M.Z.; RAGA, A.; DE SOUZA FILHO, M.F. Abamectin resistance in Tetranychus urticae Koch (Acari: Tetranychidae): selection, crossresistance and stability of resistance. Neotropical Entomology, Londrina, v. 34, n. 6, p. 991-998, 2005.

SATO, M.E.; DA SILVA, M.Z.; DE SOUZA FILHO, M.F.; MATIOLI, A.L.; RAGA, A. Management of Tetranychus urticae (Acari: Tetranychidae) in strawberry fields with Neoseiulus californicus (Acari: Phytoseiidae) and acaricides. Experimental and Applied Acarology, Amsterdam, v. 42, n. 2, p. 107-20, 2007.

SCHNEIDER, S.; WIDMER, F.; JACOT, K.; KÖLLIKER, R.; ENKERLI, J. Spatial distribution of Metarhizium clade 1 in agricultural landscapes with arable land and different semi-natural habitats. Applied Soil Ecology, Amsterdam, v. 52, p. 20-28, 2012.

STEINWENDER, B.M.; ENKERLI, J.; WIDMER, F.; EILENBERG, J.; THORUPKRISTENSEN, K.; MEYLING, N.V. Molecular diversity of the entomopathogenic fungal Metarhizium community within an agroecosystem. Journal of Invertebrate Pathology, San Diego, v. 123, p. 6-12, 2014.

STEINWENDER, B.M.; ENKERLI, J.; WIDMER, F.; EILENBERG, J.; KRISTENSEN, H.L.; BIDOCHKA, M.J.; MEYLING, N.V. Root isolations of Metarhizium spp. from crops reflect diversity in the soil and indicate no plant specificity. Journal of Invertebrate Pathology, San Diego, v. 132, p. 142-148, 2015.

VEGA, F.E.; MEYLING, N.V.; LUANGSA-ARD, J.J.; BLACKWELL, M. Fungal entomopathogens. In: VEGA, F.E.; KAYA, H.K. (Ed.). Insect pathology. San Diego: Academic Press, 2012. cap. 6, p. 171-220.

VEGA, F.E.; GOETTEL, MARK, S.; BLACKWELL, M.; CHANDLER, D.;JACKSON, M.A.; KELLER,S.; KOIKE, M.; MANIANIA, N.K.; MONZÓN, A.; OWNLEY, B.H.; PELL, J.K.; RANGEL, D.E.N.; ROY, H.E. Fungal entomopathogens: new insights on their ecology. Fungal Ecology, Manchester, v. 2, n. 4, p. 149-159, 2009.

VIEIRA TIAGO, P.; PORTO CARNEIRO-LEÃO, M.; MALOSSO, E.; TINTI DE OLIVEIRA, N.; DE LUNA ALVES LIMA, E.Á. Persistence and effect of Metarhizium anisopliae in the fungal community of sugarcane soil. BioControl, Dordrecht, v. 57, n. 5, p. 653-661, 2012.

WILSON, C.; TISDELL, C. Why farmers continue to use pesticides despite environmental, health and sustainability costs. Ecological Economics, Amsterdam, v. 39, n. 3, p. 449-462, 2001. 
WYREBEK, M.; HUBER, C.; SASAN, R.K.; BIDOCHKA, M.J. Three sympatrically occurring species of Metarhizium show plant rhizosphere specificity. Microbiology, Reading, v. 157, n. 10, p. 2904-2911, 2011.

YÁÑEZ, M.; FRANCE, A. Effects of fungicides on the development of the entomopathogenic fungus metarhizium anisopliae var. anisopliae. Chilean Journal of Agricultural Research, Santiago de Chile, v. 70, n. 3, p. 390-398, 2010.

Manuscript 2

TITLE: Diversity and abundance of Brazilian and Danish Metarhizium spp. in organic and conventional strawberry crop soil.

Thiago Castro ${ }^{1,2}$, Jørgen Eilenberg'; Nicolai V. Meyling ${ }^{2}$, Rafael de Andrade Moral ${ }^{3}$, Clarice Garcia Borges Demétrio ${ }^{3}$ \& Italo Delalibera Jr. ${ }^{1}$

${ }^{1}$ Department of Entomology and Acarology, ${ }^{3}$ Department of Exact Sciences, ESALQUniversity of São Paulo; Av Padua Dias, 11 - P.O. Box 9 - 13418-900, Piracicaba-SP; Brazil.

2 Department of Plant and Environmental Sciences, University of Copenhagen, Thorvaldsensvej 40, 1871 Frederiksberg C, Denmark

*Corresponding author. Email: thiago.castro@usp.br 


\title{
3 DIVERSITY AND ABUNDANCE OF BRAZILIAN AND DANISH Metarhizium spp. IN ORGANIC AND CONVENTIONAL STRAWBERRY CROP SOIL
}

\begin{abstract}
Studies on the community composition and population structure of entomopathogenic fungi are imperative to link to ecosystem functions such as the contribution to conservation biological control. We studied the diversity and abundance of Metarhizium species isolated from soil from conventionally and organically grown strawberry crops and the field margins in two different climatic zones: Brazil (tropical) and Denmark (temperate). In Brazilian strawberry soil, M. robertsii ( $n=129$ isolates) was the most commonly species, followed by an undescribed species, Metarhizium sp. Indet. $1(n=16) ; M$. anisopliae $(n=6) ;$ a new taxonomically unassigned lineage, Metarhizium sp. Indet. $5(n=4)$ reported here for the first time; $M$. pingshaense $(n=1)$ and $M$. brunneum $(\mathrm{n}=1)$. In Denmark, species composition was very different from Brazil, with $M$. brunneum ( $n=31)$ being the most common species, followed by $M$. flavoviridae $(n=6)$ and $M$. pemphigi $(n=5)$, detected for the first time in Denmark. No overall difference between the two climatic regimes was detected about the density of Metarhizium spp. In soil in strawberries, we found indication that soil in organically grown strawberries harbored a more diverse population of Metarhizium species compared with conventionally grown strawberries.
\end{abstract}

Keywords: Microbial control; Population ecology; Fungal community structure; Insect baiting; Colony-forming unit

\subsection{Introduction}

Brazilian climate is mostly tropical with 12 months with mean temperatures $\geq 18^{\circ} \mathrm{C}$ and day length relatively constant throughout the year, while seasonal variations are mostly dominated by variation in precipitation (ALVARES et al., 2013). Denmark is characterized by a temperate climate with 12 months with mean temperatures $\geq 10^{\circ} \mathrm{C}$ and variable day length throughout the year and seasonal variation consists of four well distinguished seasons (AGERSKOV et al., 2015). Strawberry Fragaria $\times$ ananassa (Rosales: Rosacea) is a growing and profitable promising market in both countries. Brazil produced more than three thousand tons, producing $8,500 \mathrm{~kg} / \mathrm{ha}$ while Denmark produced more than six thousand tons producing 6,200 kg/ha in 2013 (FAO, 2016).

Although Brazil and Denmark have different climates, they share several pests in strawberries, such as the two-spotted spider mite (Tetranychus urticae Koch). The main strategy to fight against these mites and other pests in strawberries is mostly by using chemical control (WILSON; TISDELL, 2001), despite the high load of pesticides which may interfere with the action of naturally occurring pest enemies, such as 
entomopathogenic fungi (SATO et al., 2007). Further, producers have experienced problems with decreased efficacy of products for chemical control, most likely due to the selection of resistant populations in strawberry (SATO et al., 2005). This conventional management increases the risk of pesticides residues in fruits, as well as the contamination of the environment and the poisoning of farmers (MAREDIA, 2003). Therefore, it is essential that novel possibilities to control mites in strawberries are explored.

Organic crop system uses several non-chemical methods for pest management (SUNDRUM, 2001; SEUFERT et al., 2012), which also can be used in conventional production. Biological control is one option, for example the use of insect pathogenic fungi. The genus Metarhizium (Hypocreales: Clavicipitaceae) contains species that occur naturally in soil (KLINGEN; HAUKELAND, 2006; MEYLING; HAJEK, 2009; MEYLING et al., 2011) and infect insects above- and belowground. Over 170 products have been developed based on at least 12 species of fungi (FARIA; WRAIGHT, 2007). Much effort has been put into the development of biological control products based on Metarhizium spp. to be applied in agriculture and forestry throughout the world, mainly for inundative biological control (ZIMMERMANN, 2007). For example, M. anisopliae is a biocontrol agent against spittlebugs (Hemiptera) in sugarcane in Brazil since many years and it is estimated that around two million hectares are sprayed every year (PARRA, 2014).

Although Metarhizium have been intensely used for pest control, limited focus has been given to the assessment of natural abundance and distribution of this widespread fungal genus (KEYSER et al., 2015). Knowledge of the community composition and population structure of this fungal genus is important to understand their ecological function and contribution to host regulation and potential for conservation biological control (MEYLING; EILENBERG, 2007). Maniania et al. (2008) also highlighted the importance of bioprospection for obtaining more isolates and species of entomopathogenic fungi with varied virulence from diverse geographic regions and hosts allowing to increase biological control efficacy in different agroecosystems.

The aim of the current study was to compare the natural diversity and abundance of Metarhizium spp. obtained from soil of conventional and organic strawberry crops and its margins in Brazil (tropical) and Denmark (temperate) using novel molecular tools to allow haplotype detection. 


\subsection{Material and Methods}

\subsubsection{Soil Sampling}

Brazil

Soil samples were taken at four sampling time points: 1) September $4^{\text {th }}, 2012$; 2) January $9^{\text {th }}, 2013$; 3) April $16^{\text {th }}, 2013$, and 4) August 21 $1^{\text {th }}, 2013$; in three locations in South of Minas Gerais state in Brazil, in organic and conventional management production system in each location: Estiva (conventional: 46 01' 39"W, 220 26' 07"S

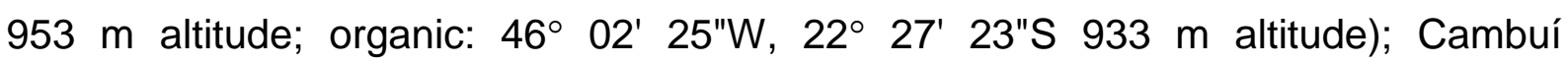
(conventional: $46^{\circ} 03^{\prime} 077^{\prime \prime} \mathrm{W}, 22^{\circ} 37^{\prime} 20^{\prime \prime S} 912 \mathrm{~m}$ altitude; organic: $46^{\circ} 03^{\prime} 04 " \mathrm{~W}, 22^{\circ}$ 34' 34"S $860 \mathrm{~m}$ altitude) and Senador Amaral (conventional: $46^{\circ} 12^{\prime} 066^{\prime \prime} \mathrm{W}, 22^{\circ} 36^{\prime}$ $21^{\prime \prime S} 1500$ m altitude; organic: $46^{\circ} 11^{\prime} 05^{\prime \prime} \mathrm{W}, 22^{\circ} 34^{\prime} 41^{\prime \prime S} 1543 \mathrm{~m}$ altitude).

Denmark

Two sampling time points, June $11^{\text {th }}, 2014$ and October $22^{\text {th }}, 2014$, in organic and conventional production system were performed in Denmark; in two locations: Klippinge (conventional: $12^{\circ} 18^{\prime} 47^{\prime \prime E}, 55^{\circ} 21^{\prime} 29^{\prime \prime} \mathrm{N} 2569$ m altitude; organic: $12^{\circ} 18^{\prime}$ $51^{\prime \prime E}, 55^{\circ} 21^{\prime} 52$ "N $2570 \mathrm{~m}$ altitude) and Skælskør (conventional: $11^{\circ} 20^{\prime} 044^{\prime \prime E}, 55^{\circ} 17^{\prime}$ $02 " \mathrm{~N} 2560 \mathrm{~m}$ altitude; organic: $11^{\circ} 20^{\prime} 08^{\prime \prime E}, 55^{\circ} 16^{\prime} 46^{\prime \prime} \mathrm{N} 2549$ m altitude).

\subsubsection{Sampling method}

The soil was taken from five plots (beds) of the strawberry crops at each farm from a depth of 0-10 $\mathrm{cm}$, using a cylindrical sampler with defined volume $\left(70 \mathrm{~cm}^{3}\right)$ (INGLIS et al. 2012). The samples were stored in sterile plastic bags and kept within Styrofoam box with ice during transport to the laboratory. Five sub-samples of soil were taken per plot with $2 \mathrm{~m}$ distance apart, forming one composite sample per plot. In addition, four sub-samples were taken from the soil $10 \mathrm{~cm}$ from the roots of the most abundant specie of spontaneous herb in the margin of the crop field (maximum $3 \mathrm{~m}$ distance). A total of five samples were taken on each farm, totalizing 25 sub-samples per farm of strawberry and 20 sub-samples per farm of soil around spontaneous herb of the crop margins in each date and location, summing up 300 sub-samples in Brazil and 100 in Denmark inside the strawberry crop and 240 sub-samples in Brazil and 80 in Denmark for margins crop soil. 


\subsubsection{Isolation of entomopathogenic fungi}

The isolation of entomopathogenic fungi from the soil was carried out using selective agar medium and insect baiting as described in chapter two (Item 2.2.5).

\subsubsection{Molecular identification of entomopathogenic Hypocreales fungi}

\subsubsection{DNA extraction}

DNA was extracted from the 203 isolates using the same procedure as described in chapter two (Item 2.4.1).

\subsubsection{PCR amplification and sequencing}

The methods used for amplification and sequencing followed the steps of Steinwender et al. (2014). The diversity of Metarhizium spp. was estimated by sequences of the nuclear intergenic (IGS) marker MzFG543igs (KEPLER; REHNER, 2013). The nuclear encoded translation elongation factor 1 -alpha (5'-TEF1- $\alpha$ ) of each haplotype was sequenced for assignment to species level (BISCHOFF et al., 2009). This was carried out by PCR amplifications of one representative isolate of each haplotype with markers EF2F (5'-GGAGGACAAGACTCACATCAACG- 3') and EFjR (5'-TGYTCNCGRGTYTGNCCRTCYTT-3') and for all isolates with markers MzFG543igs_1F (5'-ATTCATTCAGAACGCCTCCAA-3') and MzFG543igs_4R (5'GGTTGCGACTGAGAATCCATG-3'). PCR products were purified using the geneMAG-PCR Kit (Chemicell, Germany) and sequenced. Sequencing was performed by Beckman Coulter Genomics (United Kingdom).

Sequences were edited and aligned with 52 reference sequences obtained from GenBank, representing ex-type cultures or taxonomically confirmed isolates of $M$. acridum, M. anisopliae, M. brunneum, M. flavoviridae, M. guizhouense, M. lepidiotae, M. majus, M. minus, M. pemphigi, M. pingshaense and M. robertisii, (BISCHOFF et al., 2009; ROCHA et al., 2009, 2013; LOPES; MESQUITA, 2013; LOPES; SOUZA, 2013; LOPES et al., 2014; STEINWENDER et al., 2014) three indeterminate species of Metarhizium (M. sp. Indet 1, 2 and 3) and two species not identified (REZENDE, 2014; REZENDE et al., 2015; ZANARDO, 2015; IWANICKI, 2016) using MAFFT with the FFT-NS-i alignment option in Geneious 7.1.8. software (KEARSE et al., 2012). The 
sequence of $M$. minus (ARSEF1099) was included as outgroup and jModelTest 2.1.7 (DARRIBA et al., 2012) was used to calculate the evolution model for the phylogenetic tree (best-fit models of nucleotide substitution). The most parsimonious tree was calculated based on Bayesian (GTR-GAMMA) and Maximum Likelihood (GTRGAMMA) model parameters using 1000 bootstrap replicates with the software Geneious 7.1.8 (KEARSE et al., 2012) of the gene alignments of 5'-TEF1- $\alpha$. The Haplotype network was done using the intergenic spacer region IGS (MzFG543igs) and 203 sequences were obtained from the fungi sampled in Brazilian and Danish strawberry crop soil and in field margins generating 17 haplotypes. Gathering this sequences with 14 sequences from ex-type cultures or taxonomically authenticated reference (ARSEF, ESALQ, CBS and KVL) totalizing 225 sequences, in which 31 haplotypes were set and run with 100 fixed steps connection limit and gaps equal missing data using the software TCS: Phylogenetic network estimation using statistical parsimony 1.21 (CLEMENT et al., 2000) and Network 4.6.1.3. (BANDELT et al., 1999).

\subsubsection{Statistical Analyses}

Analysis of variance models were fitted to the logarithm of Metarhizium CFU (selective agar medium method) and the average proportion of infected insects (insect baiting method) data including the effects of location (Brazil: Estiva; Cambuí; Senador Amaral; Denmark: Klippinge or Skælskør) where the soil was sampled as random and the effects of sampling date (Sep/12; Jan/13; Apr/13, Aug/13, Jul/14 or Oct/14), management (conventional or organic), and place of sampling (inside the crop or in field margins) and their interactions as fixed for each Country.

\subsubsection{Diversity analyses}

The Shannon-Wiener diversity index (SHANNON, 1948) was calculated by using the haplotypes as operational taxonomic unit (OTU) and using the software DivEs 3.0.7.1385 (RODRIGUES, 2015). The haplotype and nucleotide diversity index were calculated using the DnaSP 5 (LIBRADO; ROZAS, 2009) and the Analyses of Molecular Variance (AMOVA) was done using the software Arlequin 3.5.2.2 (EXCOFFIER, 2010). 


\subsection{Results}

\subsubsection{Abundance of Metarhizium spp. in strawberry crops}

There was no significant effect of country on abundance of Metarhizium spp. (CFU/g of soil) (Figure 3.1a) using the selective agar medium method and hence analyses were split by Country $\left(F_{1,34=0.01}, p=0.93\right)$. For Brazil, the only significant difference was found between the dates of sampling (Table 3.1) where density of Metarhizium sp. was lower in August $2013\left(4.17 \pm 0.34 \times 10^{3}\right)$ then in January 2013 $\left(2.85 \pm 0.62 \times 10^{4}\right)\left(F_{3,28}=3.80 ; p \leq 0.02\right)$. The highest mean of Metarhizium spp. CFU/g of soil $\left(8.00 \pm 1.78 \times 10^{2}\right)$ was found in Senador Amaral in April 2013. For Denmark, the only difference was found in the interaction between management and dates where density of Metarhizium sp. was lower in conventional management system in October $2014\left(3.00 \pm 1.08 \times 10^{4}\right)$ then in organic management system in the same date $(9.00 \pm$ $\left.2.61 \times 10^{4}\right)$, and was lower in June $2014\left(2.75 \pm 1.03 \times 10^{4}\right)$ then October $2014(9.00 \pm$ $\left.2.61 \times 10^{4}\right)$ for organic management system $\left(F_{1,6}=9.44 ; p \leq 0.02\right)$. The highest total mean of Metarhizium spp. CFU/g of soil $\left(3.85 \pm 0.86 \times 10^{3}\right)$ was recorded in Skælskør in June 2014

There was no significant effect of country on the proportion of infected $T$. molitor larvae (Figure 3.1b) using the insect bait method and hence analyses were split by country $\left(F_{1,34}=0.35, p=0.56\right)$. In Brazil, the only difference was found between the dates of sampling where the proportion of infected insects was higher in August 2013 (40.5 $\pm 9.52 \%)$ than September $2012(11.5 \pm 4.2 \%)$, January $2013(13.3 \pm 3.8 \%)$ and April $2013(14.7 \pm 5.1 \%)\left(F_{3,28}=4.91 ; p<0.01\right)$. The highest proportion of $T$. molitor larvae killed by Metarhizium spp. $(74 \pm 4.5 \%)$ was recorded in organic management system soil of Cambuí in August 2013. In Denmark, no difference was found on proportion of infected insects for any of the parameters evaluated (location, date, management). The highest proportion of $T$. molitor larvae killed by Metarhizium spp. (38 $\pm 7.7 \%$ ) was recorded in organic management system soil of Klippinge in June 2014. 


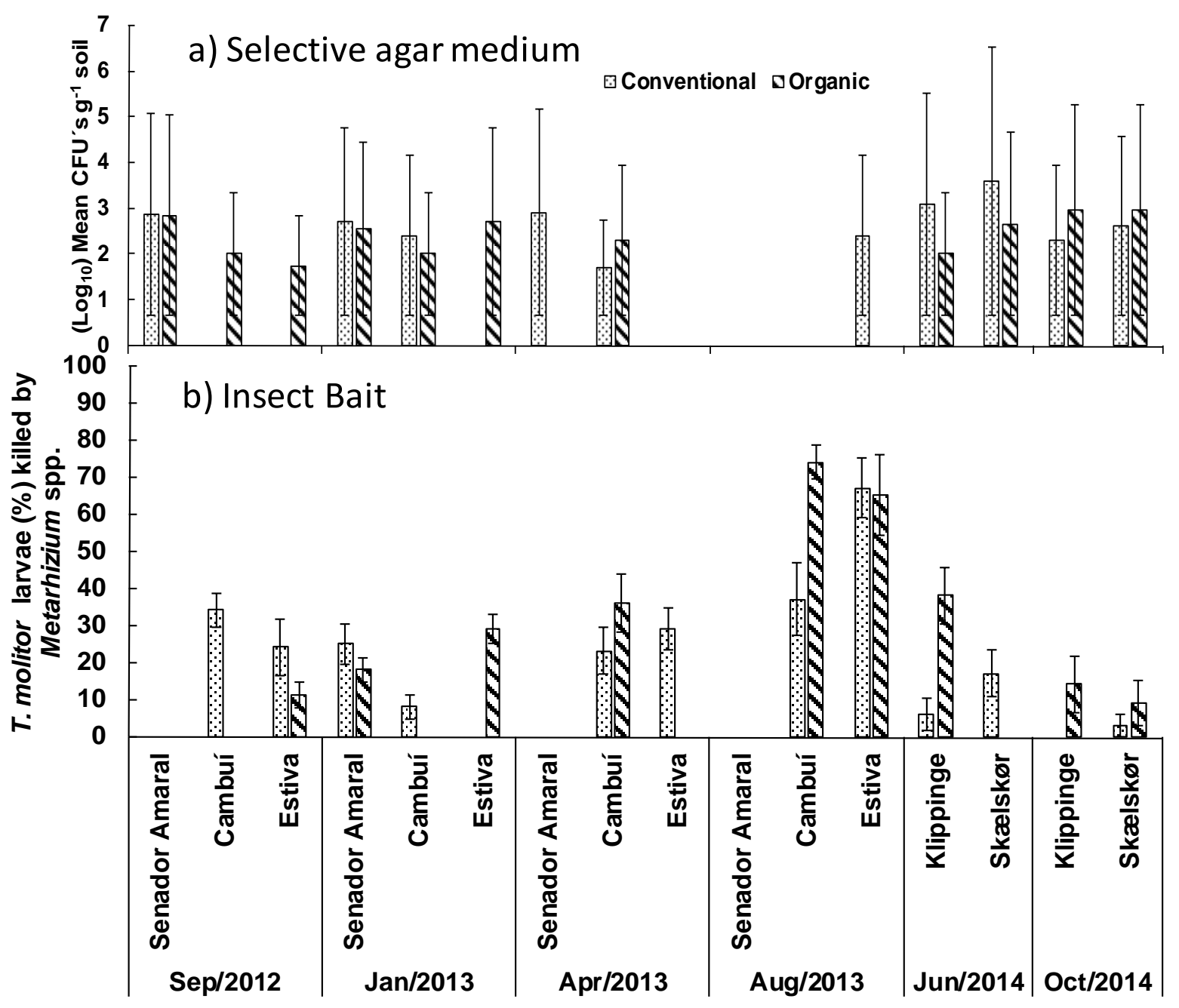

Figure 3.1 - a) Density [Colony forming units (CFU \pm SE) per gram of humid soil] of Metarhizium spp. in strawberry crop soil in Brazil. b) Mortality (Mean \pm SE) of Tenebrio molitor larvae used in the isolation of Metarhizium spp. by the insect bait method 
Table 3.1 - Analysis of variance output of the logarithm of Metarhizium CFU, and average proportion of infected insects (insect baiting method) including the effects of place of sampling and Farm as random and the effects of Date, Management and place of sampling and their interactions as fixed for each Country

\begin{tabular}{lcccc}
\hline \multirow{1}{*}{\begin{tabular}{c}
$c$ \\
\multicolumn{1}{c}{ Effect }
\end{tabular}} & \multicolumn{2}{c}{ Brazil } & \multicolumn{2}{c}{ Denmark } \\
& Test statistic & p-value & Test-statistic & p-value \\
\hline Place of sampling & $F_{1,28}=0.01$ & 0.93 & $F_{1,6}=1.03$ & 0.35 \\
Date & $F_{3,28}=3.80$ & $\mathbf{0 . 0 2}$ & $F_{1,6}=0.18$ & 0.69 \\
Management & $F_{1,2=0.02}$ & 0.89 & $F_{1,1}=4.17$ & 0.29 \\
Place of sampling x & $F_{1,28}=0.38$ & 0.55 & $F_{1,6}=0.56$ & 0.48 \\
Management & & & & \\
Place of sampling x Date & $F_{3,28}=0.19$ & 0.90 & $F_{1,6}=0.74$ & 0.42 \\
Management x Date & $F_{3,28}=0.96$ & 0.43 & $F_{1,6}=9.44$ & 0.02 \\
Place of sampling x & $F_{3,28=0.08}$ & 0.97 & $F_{1,6}=0.81$ & 0.40 \\
Management x Date & & & & \\
\hline
\end{tabular}

Insect Bait method analyses

\begin{tabular}{|c|c|c|c|c|}
\hline Location & $F_{1,28<0.01}$ & 0.96 & $F_{1,6}=1.38$ & 0.28 \\
\hline Date & $F_{3,28}=4.91$ & $<0.01$ & $F_{1,6}=2.27$ & 0.18 \\
\hline Management & $\mathrm{F}_{1,2}=0.48$ & 0.56 & $F_{1,1}=0.38$ & 0.65 \\
\hline Location x Management & $F_{1,28}=0.02$ & 0.89 & $F_{1,6}=1.30$ & 0.30 \\
\hline Location $\times$ Date & $F_{3,28}=0.17$ & 0.92 & $F_{1,6}=2.06$ & 0.20 \\
\hline Management x Date & $F_{3,28}=0.93$ & 0.44 & $F_{1,6}=0.14$ & 0.72 \\
\hline $\begin{array}{l}\text { Location x Management } \mathrm{x} \\
\text { Date }\end{array}$ & $F_{3,28}=0.04$ & 0.99 & $F_{1,6}=0.06$ & 0.81 \\
\hline
\end{tabular}

\subsubsection{Diversity of Metharizium spp. in strawberry crops}

The 203 isolates were grouped in 17 haplotypes based on the MzFG543igs (Figure 3.2) and a haplotype network was performed (Figure 3.3).

\subsubsection{Brazil}

Based on 5'TEF1- $\alpha$ gene analysis, the Brazilian isolates had representatives from six Metarhizium species. The single haplotype of $M$. anisopliae ( $\mathrm{n}=6$ isolates) clustered with Mani2 clade (Figure 3.2). M. robertsii $(n=131)$, was the most abundant but only 3 haplotypes were found, all isolates clustered with Mrob4 clade except one 
isolate that clustered with Mrob1 clade. Two haplotypes of Metarhizium sp. Indeterminate $1 \quad(n=16)$, one haplotypes each of $M$. pingshaense $(n=1)$ and $M$. brunneum $(n=1)$ and two haplotypes of a taxonomically unassigned lineage between $M$. acridum and $M$. lepidiotae with great support in both Bayesian and maximum likelihood analyses. This new lineage is referred to here as Metarhizium sp. Indet. 5 $(n=4)$. All these isolates formed well-supported monophyletic groups with the reference sequences.

\subsubsection{Denmark}

The most representative species of the Danish isolates is $M$. brunneum $(n=33)$ and consisted of one haplotype clustering with the Danish taxonomically authenticated reference (KVL12-30) and the second haplotype with the Brazilian reference (CG1126) isolated from Hemiptera in south of Brazil. One haplotype each of M. flavoviridae $(\mathrm{n}=6)$ and M. pemphigi $(\mathrm{n}=5)$ detected for the first time in Denmark. 


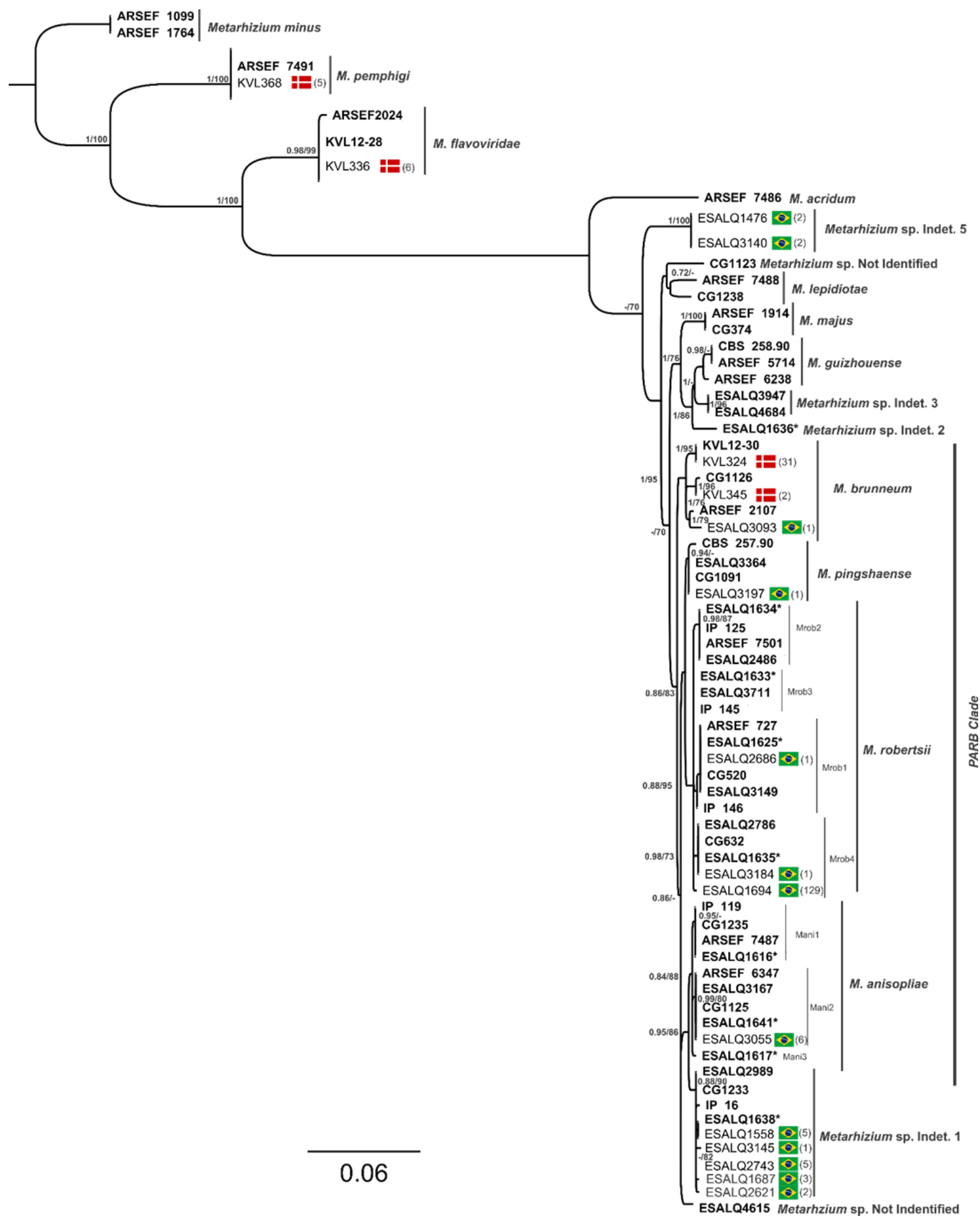

Figure 3.2 - Bayesian (B) [GTR-gamma] / Maximum likelihood (ML) [GTR-gamma] phylogeny of the data set of $5^{\prime}$ TEF sequences of 17 haplotypes found in the experiment crops, including 52 taxonomically validated reference strains (in bold) accessioned in ARSEF (ARS Entomopathogenic Fungal Culture Collection, CBS (Fungal Biodiversity Centre), ESALQ (Collection of Entomopathogenic Microorganisms of LPCMI-ESALQ-USP) CG (EMBRAPA - Cenargen) and IP (Rocha et al. 2013). Bootstrap support values $\geq 70 \%$ are listed near nodes (B/ML). Numbers in the bracket in front of the flags refer to number of isolates collected of each haplotype 


\subsubsection{Distances}

Sequence differences were compared in an alignment of 515 positions of 5'TEF1- $\alpha$ (Table 3.2). Metarhizium robertsii intraspecific differences were detected at up to four positions while intraspecific variation within M. brunneum were found up to 8 positions, Metarhizium sp. Indet. 1 intraspecific differed up to 3 base pairs, while Metarhizium sp. Indet. 5 intraspecific had 1 position difference between the two haplotypes. The longest interspecific distance was found between M. flavoviridae and the new unsigned species Metarhizium sp. Indet. 5 with 111 base pairs. The distances between M. flavoviridae and the other species were: 103 and 104 differences from Metarhizium sp. Indet. 1, 103 from M. anisopliae, 105 from M. pingshaense, 103 to 105 from M. robertsii and 80 to 105 from M. brunneum. The differences between, Metarhizium sp. Indet. 1 and Metarhizium sp. Indet. 5 ranged from 44 to 45 base pairs difference. 
Table 3.2 - Base pair difference among the 17 Metarhizium haplotypes in sequences of the $5^{\prime}$ end of Elongation Factor 1- $\alpha$ (total positions $512 \mathrm{bp})$. (Ma = Metarhzium anisopliae, $M r=M$. robertsii, $M b=M$. brunneum, $M f=M$. flavoviridae, $M p i n g=M$. pingshaense, M.sp. I. 1 = Metarhizium sp. Indet. 1, M.sp. I. $5=$ Metarhizium sp. Indet. 5 and $M p=$ M. pemphigi)

\begin{tabular}{|c|c|c|c|c|c|c|c|c|c|c|c|c|c|c|c|c|c|c|}
\hline Isolates & & $\begin{array}{c}\text { ESALQ } \\
1476\end{array}$ & $\begin{array}{c}\text { ESALQ } \\
3140\end{array}$ & $\begin{array}{c}\text { ESALQ } \\
1558\end{array}$ & $\begin{array}{c}\text { ESALQ } \\
2743\end{array}$ & $\begin{array}{c}\text { ESALQ } \\
2621\end{array}$ & $\begin{array}{c}\text { ESALQ } \\
1687\end{array}$ & $\begin{array}{c}\text { ESALQ } \\
3145\end{array}$ & $\begin{array}{c}\text { ESALQ } \\
3055\end{array}$ & $\begin{array}{c}\text { ESALQ } \\
3197\end{array}$ & $\begin{array}{c}\text { ESALQ } \\
1694\end{array}$ & $\begin{array}{c}\text { ESALQ } \\
2686\end{array}$ & $\begin{array}{c}\text { ESALQ } \\
3184\end{array}$ & $\begin{array}{c}\text { ESALQ } \\
3093\end{array}$ & $\begin{array}{c}\text { KVL } \\
324\end{array}$ & $\begin{array}{c}\text { KVL } \\
345\end{array}$ & $\begin{array}{c}\text { KVL } \\
336\end{array}$ & $\begin{array}{c}\text { KVL } \\
368\end{array}$ \\
\hline & Species & $\begin{array}{c}\text { M.sp. I. } \\
5\end{array}$ & $\begin{array}{c}\text { M.sp. I. } \\
5\end{array}$ & $\begin{array}{c}\text { M.sp. I. } \\
1\end{array}$ & $\begin{array}{c}\text { M.sp. I. } \\
1 \\
\end{array}$ & $\begin{array}{c}\text { M.sp. I. } \\
1\end{array}$ & $\begin{array}{c}\text { M.sp. I. } \\
1\end{array}$ & $\begin{array}{c}\text { M.sp. I. } \\
1\end{array}$ & Ma & M.ping & $M r$ & $M r$ & $M r$ & $M b$ & $M b$ & $M b$ & $M f$ & $M p$ \\
\hline $\begin{array}{c}\text { ESALQ } \\
1476\end{array}$ & $\begin{array}{c}\text { M.sp. I. } \\
5\end{array}$ & & & & & & & & & & & & & & & & & \\
\hline $\begin{array}{c}\text { ESALQ } \\
3140\end{array}$ & $\begin{array}{c}\text { M.sp. I. } \\
5\end{array}$ & 1 & & & & & & & & & & & & & & & & \\
\hline $\begin{array}{c}\text { ESALQ } \\
1558\end{array}$ & $\begin{array}{c}\text { M.sp. I. } \\
1\end{array}$ & 44 & 44 & & & & & & & & & & & & & & & \\
\hline $\begin{array}{c}\text { ESALQ } \\
2743\end{array}$ & $\begin{array}{c}\text { M.sp. I. } \\
1\end{array}$ & 44 & 44 & 2 & & & & & & & & & & & & & & \\
\hline $\begin{array}{c}\text { ESALQ } \\
2621\end{array}$ & $\begin{array}{c}\text { M.sp. I. } \\
1\end{array}$ & 45 & 45 & 3 & 3 & & & & & & & & & & & & & \\
\hline $\begin{array}{c}\text { ESALQ } \\
1687\end{array}$ & $\begin{array}{c}\text { M.sp. I. } \\
1\end{array}$ & 44 & 45 & 3 & 3 & 2 & & & & & & & & & & & & \\
\hline $\begin{array}{c}\text { ESALQ } \\
3145\end{array}$ & $\begin{array}{c}\text { M.sp. I. } \\
1\end{array}$ & 44 & 45 & 2 & 3 & 3 & 2 & & & & & & & & & & & \\
\hline $\begin{array}{c}\text { ESALQ } \\
3055\end{array}$ & $M a$ & 43 & 43 & 7 & 7 & 7 & 7 & 8 & & & & & & & & & & \\
\hline $\begin{array}{c}\text { ESALQ } \\
3197\end{array}$ & M.ping & 40 & 40 & 12 & 12 & 12 & 13 & 13 & 11 & & & & & & & & & \\
\hline $\begin{array}{c}\text { ESALQ } \\
1694\end{array}$ & $M r$ & 44 & 44 & 16 & 16 & 16 & 17 & 17 & 15 & 10 & & & & & & & & \\
\hline $\begin{array}{c}\text { ESALQ } \\
2686\end{array}$ & $M r$ & 46 & 46 & 18 & 18 & 18 & 19 & 19 & 17 & 12 & 4 & & & & & & & \\
\hline $\begin{array}{c}\text { ESALQ } \\
3184\end{array}$ & $M r$ & 45 & 45 & 17 & 17 & 17 & 18 & 18 & 16 & 11 & 3 & 3 & & & & & & \\
\hline $\begin{array}{c}\text { ESALQ } \\
3093\end{array}$ & $M b$ & 44 & 44 & 20 & 20 & 20 & 21 & 21 & 19 & 18 & 20 & 22 & 21 & & & & & \\
\hline $\begin{array}{l}\mathrm{KVL} \\
324\end{array}$ & $M b$ & 33 & 33 & 11 & 12 & 12 & 13 & 13 & 12 & 12 & 14 & 15 & 15 & 8 & & & & \\
\hline $\begin{array}{l}\text { KVL } \\
345\end{array}$ & $M b$ & 31 & 31 & 11 & 12 & 12 & 13 & 13 & 12 & 13 & 15 & 15 & 15 & 7 & 6 & & & \\
\hline $\begin{array}{l}\text { KVL } \\
336\end{array}$ & $M f$ & 111 & 111 & 103 & 104 & 104 & 104 & 104 & 103 & 105 & 103 & 105 & 103 & 105 & 80 & 85 & & \\
\hline $\begin{array}{l}\text { KVL } \\
368 \\
\end{array}$ & $M p$ & 105 & 105 & 94 & 95 & 95 & 95 & 95 & 98 & 97 & 97 & 98 & 97 & 98 & 79 & 84 & 61 & \\
\hline
\end{tabular}




\subsubsection{Ecological aspects}

\subsubsection{Analyses of Molecular Variance}

The Molecular Variance between Brazil and Denmark (49.2\%) was similar to the variance within each country $(50.8 \%)(p<0.001)$ (Table 3.3$)$. The variance between organic and conventional was very small and the biggest variation was found within each management type, 99.45\% of the variance in Brazil $(p<0.01)$ and $82.41 \%$ in Denmark $(p<0.001)$.

Table 3.3 - Analyses of molecular variance (AMOVA) of Metarhizium spp. found in strawberry crops and field margins in Brazil and in Denmark

\begin{tabular}{|c|c|c|c|c|c|}
\hline Group & SS & $\begin{array}{c}\text { Variance } \\
\text { component }\end{array}$ & $\begin{array}{c}\text { Variance } \\
(\%)\end{array}$ & $\begin{array}{c}\text { Fixation Index } \\
(\phi s t)\end{array}$ & $\begin{array}{c}\mathrm{P}- \\
\text { value }\end{array}$ \\
\hline Country & & & & \multirow{3}{*}{0.49217} & \multirow[b]{3}{*}{$<0.001$} \\
\hline Among countries & 1033.5 & 14.77399 & 49.22 & & \\
\hline Within countries & 3064.1 & 15.24422 & 50.78 & & \\
\hline Brazil & & & & \multirow[b]{3}{*}{0.00547} & \multirow[b]{3}{*}{0.0136} \\
\hline $\begin{array}{c}\text { Among } \\
\text { managements }\end{array}$ & 6508 & 0.02582 & 0.55 & & \\
\hline $\begin{array}{c}\text { Within } \\
\text { managements }\end{array}$ & 7043.4 & 4.69560 & 99.45 & & \\
\hline \multirow{3}{*}{$\begin{array}{c}\text { Denmark } \\
\text { Among } \\
\text { managements } \\
\text { Within } \\
\text { managements }\end{array}$} & & & & \multirow{3}{*}{0.17590} & \multirow{3}{*}{$<0.001$} \\
\hline & 261.7 & 10.79972 & 17.59 & & \\
\hline & 1922.6 & 50.59591 & 82.41 & & \\
\hline
\end{tabular}

\subsubsection{Diversity}

The haplotype and nucleotide diversity of Metarhizium spp in Denmark ( $\mathrm{Hd}=$ $0.481, \pi=0.0780)$ was higher than Brazil $(\mathrm{Hd}=0.339, \pi=0.0102)$ but the ShannonWiener index was similar (0.3953 and 0.3935 for Brazil and Denmark) (Table 3.4). The Metarhizium spp. diversity found in organic crop systems in Denmark was higher than in conventional system for all indexes. In Brazil, the haplotype and nucleotide diversity were similar but the Shannon-Wiener index was a bit higher in the organic system. The haplotype diversity $(\mathrm{Hd})$ in the Danish organic system $(\mathrm{Hd}=0.627)$ was more than double of the diversity found in Brazil $(\mathrm{Hd}=0.300)$ in the same system. Higher 
polymorphism in the organic management was observed in Denmark with $\pi=0.1123$ almost 15 fold of the nucleotide diversity $(\pi=0.0075)$ in Brazil.

Table 3.4 - Diversity of Metarhizium spp. found in strawberry crops and field margins in Brazil and in Denmark

\begin{tabular}{ccccccccc}
\hline Group & $\mathrm{N}$ & $\mathrm{H}$ & $\mathrm{Hd}$ & $\pi$ & $\mathrm{V}$ & $\mathrm{Pi}$ & $\mathrm{S}$ & $\begin{array}{c}\text { Shannon- } \\
\text { Wiener }\end{array}$ \\
\hline Brazil & 159 & 13 & 0.339 & 0.0102 & 106 & 87 & 19 & 0.3953 \\
Conventional & 100 & 9 & 0.299 & 0.0108 & 98 & 84 & 14 & 0.3338 \\
Organic & 59 & 7 & 0.300 & 0.0075 & 45 & 41 & 4 & 0.4227 \\
\hline Denmark & 44 & 4 & 0.481 & 0.0780 & 200 & 200 & 0 & 0.3935 \\
Conventional & 27 & 3 & 0.236 & 0.0440 & 198 & 150 & 48 & 0.2042 \\
Organic & 17 & 3 & 0.627 & 0.1123 & 198 & 198 & 0 & 0.5106 \\
\hline
\end{tabular}

\subsubsection{Haplotype network}

The M. robertsii haplotype $11(\mathrm{H} 11)$ was the most commonly found $(\mathrm{n}=129$ isolates) and was consistently distributed in the sampled area, $31 \%$ was observed in soil of the conventional management system, $31 \%$ in the margins of the conventional field, $24 \%$ in the organic system and $14 \%$ in margins of the organic system (Figure 3.3). The M. brunneum haplotype $1(\mathrm{H} 1)$ was the most commonly found ( $\mathrm{n}=30$ isolates) in Denmark with $44 \%$ of isolates found in margins of conventional system, $28 \%$ inside the conventional system, $22 \%$ inside the margins of organic system and $6 \%$ in the margins of the organic fields.

Metarhizium sp. Indet. 1 haplotypes ( $\mathrm{H} 9$ and $\mathrm{H} 10$ ) was the second most common species in Brazil and was found in most of the sampled areas, and it was more abundant than the only haplotype $(\mathrm{H} 6)$ of $M$. anisopliae which was found only in the organic system and in margins of the conventional system. The second most common species in Denmark, M. flavoviridae $(\mathrm{H} 24)$ was found only in margins of the organic and conventional systems ( $67 \%$ and $33 \%$, respectively).

The two haplotypes ( $\mathrm{H} 21$ and H22) of the Metarhizium sp. Indet. 5 were found only in margins of the conventional system in Brazil. M. pemphigi was found only in Denmark (H25), $40 \%$ in margins of the conventional system, $40 \%$ in the organic crops and $20 \%$ in conventional crops. 


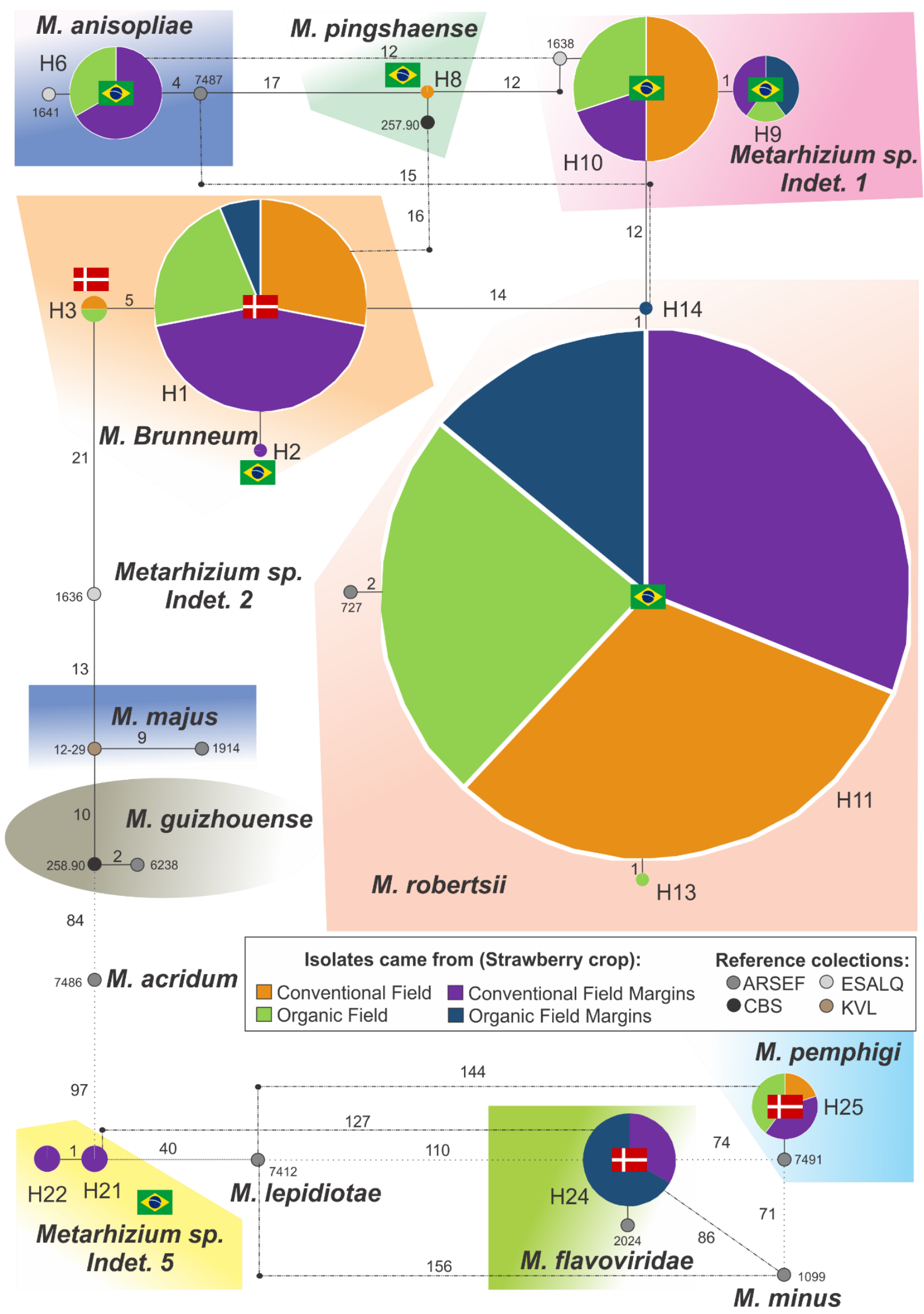

Figure 3.3 - Haplotype network of Metarhizium spp. found in strawberry crops and field margins in Brazil and in Denmark 


\subsection{Discussion}

This is the first study comparing directly the diversity and abundance of Metarhizium species in the same crop (strawberry) grown under two very different climatic regimes. Sun and Liu (2008) compared the occurrence and the species diversity of fungi in soil of different climatic regions of China, and they found in overall that $10.6 \%$ of the entomopathogenic fungi isolated belonged to those Metarhizium anisopliae sensu lato, but with some geographical difference related to the four different climatic zones of sampling. Our comparison is, however, different, since we restricted our studies to solely two climatic regimes, one crop, but then actually both hemispheres and we used the new multilocus phylogenic classification focusing only in Metarhizium spp. Also, our haplotype assessment gave a much higher resolution of the diversity found than in previous Metarhizium studies.

Metarhizium community in temperate North America appeared to be dominated by M. brunneum, M. robertsii and M. guizhouense (FISHER et al., 2011; WYREBEK et al., 2011; KEPLER et al., 2015), with M. anisopliae a minor component or absent altogether. Our results corroborate other studies regarding the most frequent Metarhizium species found in South America and Europe. In South America, the predominance of $M$. anisopliae and $M$. robertsii has been observed (ROCHA et al., 2009, 2013; LOPES, MESQUITA, 2013; LOPES; SOUZA, 2013; LOPES et al., 2014; REZENDE et al., 2015). In contrast, Metarhizium community in Europe appeared to be dominated by $M$. brunneum, M. flavoviride and M. robertsii (MEYLING et al., 2011; STEINWENDER et al., 2014, 2015; KEYSER et al., 2015).

Rezende et al. (2015) found two new taxonomically unassigned linages in Brazil, being phylogenetically close to $M$. anisopliae (Metarhizium sp. indet. 1) and the second more basal in the phylogenetic tree (Metarhizium sp. indet. 2). We reported here that Metarhizium sp. indet. 1 is actually more abundant in strawberry than M. anisopliae a common species in Brazil. In our study, another new taxonomically unassigned lineage was found (Metarhzium sp. Indet. 5) that is even more basal than the ones found in the previous study (REZENDE et al., 2015). There is only a single report of $M$. brunneum (LOPES et al., 2014) from Brazil and here we report a second isolate collected in the country.

The results we observed from strawberry soils corroborate other studies demonstrating that the most frequent species found in Denmark was M. brunneum (STEINWENDER et al., 2014, 2015) but differed from that observed by Keyser et al. 
(2015) where M. flavoviride was the dominant species, and M. pemphigi was detected for the first time in Denmark in our study.

We found a higher diversity of Metarhizium in organic strawberry farms in Denmark compared with conventional strawberry, which supports earlier findings in other crops. Klingen et al. (2002) found significantly higher occurrence of insect pathogenic fungi in soils from arable fields of organically managed farms in Norway. Clifton et al. (2015) compared soil-borne entomopathogenic fungi in organic and conventional fields in Midwestern USA in corn and soybean fields and found a similar result where occurrence of entomopathogenic fungi was significantly greater in the soil of organic agroecosystems than conventional. The differences between Metarhizium occurrence in conventional and organic soils were bigger in Denmark compared to Brazil. One explanation for that could be due to the definition of 'organic crop' differs between countries. In Denmark, there are stricter rules and more surveillance for organic fields than in Brazil which may lead to the suggestion that the organically grown areas in Denmark have had more time to be settled as being 'organic'. We hypothesize that if organically grown strawberries in Brazil in the future will be subjected to better surveillance it will be possible to detect differences in Metarhizium spp. composition, more comparable with the results from Denmark.

The importance of the field margins to the diversity of the fields can be seen when evaluating the haplotype network (Figure3.3). The margins seem important as a sort of biodiversity pool once the abundance of $M$. anisopliae was negatively affected by proximity to conventional fields, in accordance with Clifton et al. (2015), who suggested that cropping practices within a field can affect soil-borne microorganisms even outside the field. The management of crop margins is important to ensure the natural diversity of Metarhizium species. Overall, insufficient knowledge about main drivers in Metarhizium spp. diversity does not yet allow for general conclusions, if crop, climatic zone, or cropping system is of similar importance. Bidochka et al. (2001) reported that $M$. anisopliae population structure may be driven by habitat selection and not insect host selection. Our studies seem to support this hypothesis, although in our case the scale (climatic regimes) is larger than habitat. 
Acknowledgments

The authors are grateful to Lívia Maria Alves Porto, Giovani Marcio Coura Junior, Louise Lee Munk Larsen and Vinnie Deichmann for their technical assistance. This research was funded by the Danish Agency for Science, Technology and Innovation and The São Paulo Research Foundation (through the project IMBICONT: 'Improved biological control for IPM in fruits and berries', project number 0603-00486B and 2011/51556-3 respectively). The first author is a recipient of scholarships from the São Paulo Research Foundation (FAPESP, project number 2013/24430-4 and 2013/10517-0).

\section{References}

AGERSKOV, A.U.; BISGAARD, C.M.P.; POULIN, C.P.D. Statistical yearbook 2015. 119 ${ }^{\text {th }}$. Statistics Denmark 2015. 557 ISBN 978-87-501-2178-7. Disponível em: <www.dst.dk/yearbook>. Acesso em: 24 fev. 2016.

ALVARES, C.A.; STAPE, J.L.; SENTELHAS, P.C.; DE MORAES GONÇALVES, J.L.; SPAROVEK, G. Köppen's climate classification map for Brazil. Meteorologische Zeitschrift, Berlin, v. 22, n. 6, p. 711-728, 2013.

BANDELT, H.J.; FORSTER, P.; RÖHL, A. Median-joining networks for inferring intraspecific phylogenies. Molecular Biology and Evolution, Oxford, v. 16, p. 37-48, 1999.

BIDOCHKA, M.J.; KAMP, A.M.; LAVENDER, T.M.; DEKONING, J.; DE CROOS, J.N. Habitat association in two genetic groups of the insect-pathogenic fungus metarhizium anisopliae: uncovering cryptic species? Applied and Environmental Microbiology, Washington, v. 67, n. 3, p. 1335-1342, 2001.

BISCHOFF, J.F.; REHNER, S.A.; HUMBER, R.A. A multilocus phylogeny of the Metarhizium anisopliae lineage. Mycologia, New York, v. 101, n. 4, p. 512-30, 2009.

CLEMENT, M.; POSADA, D.; CRANDALL, K.A. TCS: a computer program to estimate gene genealogies. Molecular Ecology, Oxford, v. 9, n. 10, p. 1657-1659, 2000.

CLIFTON, E.H.; JARONSKI, S.T.; HODGSON, E.W.; GASSMANN, A.J. Abundance of soil-borne entomopathogenic fungi in organic and conventional fields in the midwestern USA with an emphasis on the effect of herbicides and fungicides on fungal persistence. PLoS One. San Francisco, v.10, e0133613, 2015.

DARRIBA, D.; TABOADA, G.L.; DOALLO, R.; POSADA, D. jModelTest 2: more models, new heuristics and parallel computing. Nature Methods, New York, v. 9, n. 8, p. 772, 2012. 
EXCOFFIER, L.A.H.E.L.L. Arlequin suite ver 3.5: A new series of programs to perform population genetics analyses under Linux and Windows. . Molecular Ecology Resources, Oxford, v. 10, p. 564-567, 2010.

FAO. FAOSTAT. 2016. Disponível em: <http://faostat3.fao.org/>. Acesso em: 21 jan. 2016.

FARIA, M.R.D.; WRAIGHT, S.P. Mycoinsecticides and mycoacaricides: a comprehensive list with worldwide coverage and international classification of formulation types. Biological Control, Orlando, v. 43, n. 3, p. 237-256, 2007.

FERNANDES, É.K.K.; KEYSER, C.A.; RANGEL, D.E.N.; FOSTER, R.N.; ROBERTS, D.W. CTC medium: a novel dodine-free selective medium for isolating entomopathogenic fungi, especially Metarhizium acridum, from soil. Biological Control, Orlando, v. 54, n. 3, p. 197-205, 2010.

FISHER, J.J.; REHNER, S.A.; BRUCK, D.J. Diversity of rhizosphere associated entomopathogenic fungi of perennial herbs, shrubs and coniferous trees. Journal of Invertebrate Pathology, San Diego, v. 106, n. 2, p. 289-295, 2011.

HUMBER, R.A. Identification of entomopathogenic fungi. In: LACEY, L.A. (Ed.). Manual of techniques in invertebrate pathology. $2^{\text {nd }}$ ed. Dordrecht: Springer, 2012. p.151-187.

INGLIS, G.D.; ENKERLI, J.; GOETTEL, M.S. Laboratory techniques used for entomopathogenic fungi: Hypocreales. In: LACEY, L.A. (Ed.). Manual of techniques in invertebrate pathology. $2^{\text {nd }}$ ed. Dordrecht: Springer, 2012. p.189-253.

IWANICKI, N.S. Monitoramento de Metarhizium spp. (Hypocreales: Clavicipitaceae) por marcadores moleculares em plantios de cana-de-açúcar. 2016. 68 p. Dissertação (Mestrado em Entomologia) - Escola Superior de Agricultura "Luiz de Queiroz", Universidade de São Paulo, Piracicaba, 2016.

KEARSE, M.; MOIR, R.; WILSON, A.; STONES-HAVAS, S.; CHEUNG, M.; STURROCK, S.; BUXTON, S.; COOPER, A.; MARKOWITZ, S.; DURAN, C.; THIERER, T.; ASHTON, B.; MENTJIES, P.; DRUMMOND, A. Geneious Basic: an integrated and extendable desktop software platform for the organization and analysis of sequence Bioinformatics, Oxford, v. 28, n. 12, p. 1647-1649, 2012.

KEPLER, R.M.; REHNER, S.A. Genome-assisted development of nuclear intergenic sequence markers for entomopathogenic fungi of the Metarhizium anisopliae species complex. Molecular Ecology Resources, Oxford, v. 13, n. 2, p. 210-217, 2013.

KEPLER, R.M.; HUMBER, R.A.; BISCHOFF, J.F.; REHNER, S.A. Clarification of generic and species boundaries for Metarhizium and related fungi through multigene phylogenetics. Mycologia, New York, v. 106, n. 4, p. 811-829, 2014. 
KEPLER, R.M.; UGINE, T.A.; MAUL, J.E.; CAVIGELLI, M.A.; REHNER, S.A. Community composition and population genetics of insect pathogenic fungi in the genus Metarhizium from soils of a long-term agricultural research system.

Environmental Microbiology, Washington, v. 17, n. 8, p. 2791-2804, 2015.

KEYSER, C.A.; DE FINE LICHT, H.H.; STEINWENDER, B.M.; MEYLING, N.V. Diversity within the entomopathogenic fungal species Metarhizium flavoviride associated with agricultural crops in Denmark. BMC Microbiology, London, v. 15, n. 1, p. 249, 2015.

KLINGEN, I.; HAUKELAND, S. The soil as a reservoir for natural enemies of pest insects and mites with emphasis on fungi and nematodes. In: EILENBERG, J.; HOKKANEN, H.M.T. (Ed.). An ecological and societal approach to biological control. Amsterdam: Springer, 2006. v. 2, chap. 9, p. 145-211. (Progress in Biological Control).

KLINGEN, I.; EILENBERG, J.; MEADOW, R. Effects of farming system, field margins and bait insect on the occurrence of insect pathogenic fungi in soils. Agriculture, Ecosystems \& Environment, Zurich, v. 91, n. 1/3, p. 191-198, 2002.

LIBRADO, P.; ROZAS, J. DnaSP v5: a software for comprehensive analysis of DNA polymorphism data. Bioinformatics, Oxford, v. 25, p. 1451-1452, 2009.

LOPES, R.B.; SOUZA, D.A.; OLIVEIRA, C.M.; FARIA, M. Genetic diversity and pathogenicity of Metarhizium spp. associated with the white grub Phyllophaga capillata (Blanchard) (Coleoptera: Melolonthidae) in a soybean field. Neotropical Entomology, Londrina, v. 42, n. 4, p. 436-438, 2013.

LOPES, R.B.; FARIA, M.; SOUZA, D.A.; BLOCH, C. JR.; SILVA, L.P.; HUMBER, R.A. MALDI-TOF mass spectrometry applied to identifying species of insectpathogenic fungi from the Metarhizium anisopliae complex. Mycologia, New York, v. 106, n. 4, p. 865-878, 2014.

LOPES, R.B.; MESQUITA, A.L.M.; TIGANO, M.S.; SOUZA, D.A.; MARTINS, I.; FARIA, M. Diversity of indigenous Beauveria and Metarhizium spp. in a commercial banana field and their virulence toward Cosmopolites sordidus (Coleoptera: Curculionidae). Fungal Ecology, Manchester, v. 6, n. 5, p. 356-364, 2013.

MANIANIA, N.K.; BUGEME, D.M.; WEKESA, V.W.; DELALIBERA, I. JR.; KNAPP, M. Role of entomopathogenic fungi in the control of Tetranychus evansi and Tetranychus urticae (Acari: Tetranychidae), pests of horticultural crops.

Experimental and Applied Acarology, Amsterdam, v. 46, n. 1/4, p. 259-274, 2008.

MAREDIA, K.M. Introduction and overview. In: MAREDIA, K. M.; MOTA-SANCHEZ, D.; DAKOUO, D. (Ed.). Integrated pest management in the global arena.

Cambridge: CABI, 2003. p. 512. 
MEYLING, N.V.; EILENBERG, J. Ecology of the entomopathogenic fungi Beauveria bassiana and Metarhizium anisopliae in temperate agroecosystems: Potential for conservation biological control. Biological Control, Orlando, v. 43, n. 2, p. 145-155, 2007.

MEYLING, N.V.; HAJEK, A.E. Principles from community and metapopulation ecology: application to fungal entomopathogens. BioControl, Dordrecht, v. 55, n. 1, p. 39-54, 2009.

MEYLING, N.V.; THORUP-KRISTENSEN, K.; EILENBERG, J. Below- and aboveground abundance and distribution of fungal entomopathogens in experimental conventional and organic cropping systems. Biological Control, Orlando, v. 59, n. 2, p. 180-186, 2011.

PARRA, J.R.P. Biological control in Brazil: an overview. Scientia Agricola, Piracicaba, v. 71, n. 5, p. 420-429, 2014.

REZENDE, J.M. Diversidade filogenética e expressão de genes de virulência de Metarhizium com ênfase em isolados brasileiros associados a cultura da canade-açúcar. 2014. 138 p. (Doutorado em Entomologia) - Escola Superior de Agricultura "Luiz de Queiroz", Universidade de São Paulo, Piracicaba, 2014.

REZENDE, J.M.; ZANARDO, A.B.R.; LOPES, M.D.; DELALIBERA, I.; REHNER, S.A. Phylogenetic diversity of Brazilian Metarhizium associated with sugarcane agriculture. BioControl, Dordrecht, v. 60, n. 4, p. 495-505, 2015.

ROCHA, L.F.; INGLIS, P.W.; HUMBER, R.A.; KIPNIS, A.; LUZ, C. Occurrence of Metarhizium spp. in Central Brazilian soils. Journal of Basic Microbiology, Berlin, v. 53, n. 3, p. 251-259, 2013.

ROCHA, L.F.N.; TAI, M.H.H.; SANTOS, A.H.D.; ALBERNAZ, D.A.D.S.; HUMBER, R.A.; LUZ, C. Occurrence of invertebrate-pathogenic fungi in a Cerrado ecosystem in Central Brazil. Biocontrol Science and Technology,Oxfod, v. 19, n. 5, p. 547-553, 2009.

RODRIGUES, W.C. DivEs: diversidade de espécies v3.0; guia do usuário. Entomologistas do Brasil, 2015. 33 p. Disponível em: <http://dives.ebras.bio.br> Acesso em: 24 fev. 2016.

SATO, M.E.; DA SILVA, M.Z.; RAGA, A.; DE SOUZA FILHO, M.F. Abamectin resistance in Tetranychus urticae Koch (Acari: Tetranychidae): selection, crossresistance and stability of resistance. Neotropical Entomology, Londrina, v. 34, n. 6, p. 991-998, 2005.

SATO, M.E.; DA SILVA, M.Z.; DE SOUZA FILHO, M.F.; MATIOLI, A. L.; RAGA, A. Management of Tetranychus urticae (Acari: Tetranychidae) in strawberry fields with Neoseiulus californicus (Acari: Phytoseiidae) and acaricides. Experimental and Applied Acarology, Amsterdam, v. 42, n. 2, p. 107-120, 2007. 
SEUFERT, V.; RAMANKUTTY, N.; FOLEY, J.A. Comparing the yields of organic and conventional agriculture. Nature, London, v. 485, n. 7397, p. 229-232, 2012.

SHANNON, C.E. A mathematical theory of communication. Bell System Technical Journal, New York, v. 27, n. 3, p. 379-423, 1948.

STEINWENDER, B.M.; ENKERLI, J.; WIDMER, F.; EILENBERG, J.; KRISTENSEN, H.L.; BIDOCHKA, M.J.; MEYLING, N V. Root isolations of Metarhizium spp. from crops reflect diversity in the soil and indicate no plant specificity. Journal of Invertebrate Pathology, San Diego, v. 132, p. 142-148, 2015.

STEINWENDER, B.M.; ENKERLI, J.; WIDMER, F.; EILENBERG, J.; THORUPKRISTENSEN, K.; MEYLING, N.V. Molecular diversity of the entomopathogenic fungal Metarhizium community within an agroecosystem. Journal of Invertebrate Pathology, San Diego, v. 123, p. 6-12, 2014.

SUN, B.-D.; LIU, X.-Z. Occurrence and diversity of insect-associated fungi in natural soils in China. Applied Soil Ecology, Amsterdam, v. 39, n. 1, p. 100-108, 2008.

SUNDRUM, A. Organic livestock farming: a critical review. Livestock Production Science, Amsterdam, v. 67, n. 3, p. 207-215, 2001.

WILSON, C.; TISDELL, C. Why farmers continue to use pesticides despite environmental, health and sustainability costs. Ecological Economics, Amsterdam, v. 39, n. 3, p. 449-462, 2001.

WYREBEK, M.; HUBER, C.; SASAN, R.K.; BIDOCHKA, M.J. Three sympatrically occurring species of Metarhizium show plant rhizosphere specificity. Microbiology, New York, v. 157, n. 10, p. 2904-11, 2011.

ZANARDO, A.B.R. Abundância de fungos entomopatogênicos da ordem Hypocreales e diversidade genética de Metarhizium spp. isolados de amostras de solo de áreas representativas de cinco biomas brasileiros. 2015. 154 p. Tese (Doutorado em Entomologia) - Escola Superior de Agricultura "Luiz de Queiroz", Universidade de São Paulo, Piracicaba, 2015.

ZIMMERMANN, G. Review on safety of the entomopathogenic fungus Metarhizium anisopliae. Biocontrol Science and Technology, Oxford, v. 17, n. 9, p. 879-920, 2007. 
Manuscript 3

Exploring the diversity of Metarhizium spp. from Brazil for the control of the Twospotted spider mite

Thiago Castro ${ }^{1,2}$, Jørgen Eilenberg ${ }^{2}$ \& Italo Delalibera Jr. ${ }^{1}$

1 Department of Entomology and Acarology, ESALQ- University of São Paulo; Av Padua Dias, 11 - P.O. Box 9 - 13418-900, Piracicaba-SP; Brazil.

2 Department of Plant and Environmental Sciences, University of Copenhagen, Thorvaldsensvej 40, 1871 Frederiksberg C, Denmark

*Corresponding author. Email: thiago.castro@usp.br 


\title{
4 EXPLORING THE DIVERSITY OF Metarhizium spp. FROM BRAZIL FOR THE CONTROL OF THE TWO-SPOTTED SPIDER MITE
}

\begin{abstract}
The two-spotted spider mite, Tetranychus urticae is the most important pests of strawberry crops in Brazil and many other countries. Although control of this pest is mostly by chemical pesticides, the use of biological control with entomopathogenic fungi, specially Beauveria bassiana (Hypocreales: Cordycipitaceae) and Metarhizium spp. (Hypocreales: Clavicipitaceae), is increasing. With the latest changes in the classification of Metarhizium, new species has been described, but most studies are still concentrated in only three species, $M$. anisopliae, M. brunneum and $M$. robertsii. Recently, new undescribed Metarhizium species have been found in Brazil and these species may add a variety of new options in the pest control. The local species may be more adapted to specific agroecosystems and more virulent towards local pests. To test these hypotheses, the mortality of adult females of $T$. urticae by six isolates of four undescribed Metarhizium species from different regions and crops were compared to two isolates of each species of $M$. anisopliae, $M$. brunneum, $M$. pingshaense and $M$. robertsii, isolated from strawberry crops in Brazil. Beauveria bassiana ESALQPL63, commercially available in Brazil against this pest was used as control. Fungal suspensions were sprayed in laboratory at $1 \times 10^{7}$ conidia $/ \mathrm{mL}$ with $0.05 \%$ tween 80 . The best isolates were ESALQPL63 of $B$. bassiana, ESALQ1608 and ESALQ1638 of Metarhizium sp. indet. 1 and ESALQ3069 and ESALQ3222 of $M$. pingshaense based on survival curve, total mortality, percentage of sporulated cadavers and median lethal time $\left(\mathrm{LT}_{50}\right)$. The lowest $\mathrm{LT}_{50}, 4( \pm 0.17)$ was observed in mites treated with ESALQ1638 of Metarhizium sp. indet. 1. This study revealed for the first time the potential of unassigned new lineages and less studied species of Metarhizium as a biocontrol agent of $T$. urticae. These less known species should be considered in the development of new biopesticides and in further studies to assess their potential as biological control agents of other pest in the future.
\end{abstract}

Keywords: Tetranychus urticae; Microbial control; Strawberry; Beauveria bassiana; Virulence; Pathogenicity

\subsection{Introduction}

Two-spotted spider mites, Tetranychus urticae Koch (Acari: Tetranychidae) is considered one of the main pests of horticultural crops worldwide (ATTIA et al., 2013) and is one of the main pests on strawberry crops in Brazil (IWASSAKI et al., 2015), affecting crops by feeding on the undersurface of leaves covered with fine webbing, causing curling and discoloration, reducing photosynthetic activity and causing leaf abscission in severe infestations (DE MORAES ; FLECHTMANN, 2008; ATTIA et al., 2013). Tetranychus urticae has developed resistance against many chemical pesticides (STUMPF ; NAUEN, 2001; NICASTRO et al., 2010). 
One alternative to chemical pesticides is the biological control with entomopathogenic fungi, in particular species from the Ascomycota. Species from the genus Metarhizium (Hypocreales: Clavicipitaceae) are easy to mass produce and formulate, so several mycopesticides based on these fungi are available (FARIA ; WRAIGHT, 2007; VEGA et al., 2012)

Recently, after Bischoff et al. (2009) discoveries in a multilocus phylogenetic study, the fungus previous known as Metarhizium anisopliae actually comprises a nine species complex: $M$. anisopliae, $M$. guizhouense, $M$. pingshaense, $M$. acridum, $M$. majus, M. lepidiotae, M. brunneum, M. globosum and $M$. robertsii and also $M$. flavoviridae already known as a different species by its different morphology. They suggest that the most reliable way to distinguish between species within this complex is the use of molecular tools and analyzes. Based on their results, was determined that the $5^{\prime}$ region of the gene for the translational elongation factor (TEF) is the most informative region for routine use in species identification within the genus. Due to these new findings, all work done using Metarhizium spp. identified only by morphological means, makes impossible to determine the true identity of the species and because of that all studies performed without molecular identification of these fungi needs to be cited as $M$. anisopliae sensu latu (s.I.).

Besides of that, other important fact that needs to be highlighted is that most of the studies using fungi from the genus Metarhizium were performed using different isolates of the same species. Some studies show that $M$. anisopliae s.l. is pathogenic to other mite species (WEKESA et al., 2005; BUGEME, et al., 2008, 2015; SHI et al., 2008; TAVASSOLI et al., 2011; QUINELATO et al., 2012) and by that, it is possible to infer that fungi from this genus may offer a good opportunity for biological control of $T$. urticae. Testing different species of Metarhizium, identified by molecular means, may provide a more versatile background for selection of species (and not just strains or isolates) for further work.

Pathogenicity and virulence studies of Metarhizium anisopliae s.l. have been performed in T. urticae (TAMAI et al., 2002; CHANDLER et al., 2005; BUGEME et al., 2008; AMJAD et al., 2012). These kinds of laboratory bioassays are essential to select isolates for subsequent more deep and detailed studies. Such studies also work as a first step and if the results merit it, one or more isolates might then be worthy for field 
trials and, in the best case, later registration and commercialization (VEGA et al., 2012).

The following Metarhizium species are known to occur naturally in soils or insects in Brazil: M. anisopliae, M. acridum, M. majus, M. flavoviride, M. pingshaense, M. robertsii, M. brunneum, M. lepidiotae (LOPES; MESQUITA, 2013; LOPES; SOUZA, 2013; LOPES et al., 2014; REZENDE et al., 2015). Scientifically undescribed Metarhizium lineages have also been detected in Brazil: refer to as Metarhizium sp. Indet. 1, Metarhizium sp. Indet.2, Metarhizium sp. Indet.3, Metarhizium sp. Indet.4 (REZENDE, 2014; REZENDE et al., 2015; ZANARDO, 2015; IWANICKI, 2016) and Metarhizium sp. Indet.5 (T. CASTRO, unpublished). Even though these species have not been formally described yet, it will be highly relevant to evaluate their potential for pest control.

Maniania et al. (2008) highlighted the importance of bioprospection for obtaining more isolates and species of entomopathogenic fungi with varied virulence from diverse geographic regions and hosts allowing to increase biological control efficacy in different agroecosystems. A number of isolates from different species of Metarhizium have recently been obtained from soil of strawberry crops in Brazil. In this study, we aimed to compare the pathogenicity and virulence of six isolates of four undescribed Metarhizium species (from strawberry, sugarcane crops and native forest from different regions) with two isolates of each species of $M$. anisopliae, $M$. brunneum, $M$. pingshaense and $M$. robertsii, isolated from strawberry crops, all from Brazil. Also, we obtained information about host adaptation by qualitatively evaluation of sporulation from mite cadavers.

\subsection{Material and Methods}

\subsubsection{Fungal origin}

Two isolates each of M. robertsii, M. anisopliae, M. brunneum, M. pingshaense, and one isolate each of Metarhizium indet. sp. 2 and Metarhizium indet. sp. 5 obtained from strawberry crop in south of Minas Gerais State in Brazil between 2012 and 2013, as described in chapter two and three (Item 2.2.1 and 3.2.1, respectively), were selected (Table 4.1). These were compared to two isolates each of Metarhizium sp. 
indet. 1 and Metarhizium indet. sp. 4. (REZENDE, 2014; ZANARDO, 2015) from the Collection of Entomopathogenic Microorganisms of ESALQ-USP. Beauveria bassiana (ESALQPL63), commercially available in Brazil against this pest, was used as control. All fungi used were molecularly identified using 5 TEF-1 $\alpha$ marker as suggested by Bischoff et al. (2009).

\subsubsection{Tetranychus urticae stock culture}

Tetranychus urticae was reared on Jack bean plants Canavalia ensiformis (Fabales: Fabaceae) in an acclimatized room at $25^{\circ} \mathrm{C}, 60 \% \mathrm{RH}$, and $12 \mathrm{~h}$ photoperiod at the University of São Paulo (ESALQ-USP) campus in Piracicaba - SP Brazil since 2014. The plants were watered three times per week. Old and highly infested plants were replaced by new ones as required.

\subsubsection{Fungal production}

All selected isolates were grown in Petri dishes $(90 \times 15 \mathrm{~mm})$ at $25 \pm 1^{\circ} \mathrm{C}$ on PDA media (Potato Dextrose Agar, Difco ${ }^{\mathrm{TM}}, \mathrm{USA}$ ). Conidia were harvested by scraping the surface of 2-week-old sporulating cultures and then were suspended in $5 \mathrm{ml}$ sterile distilled water containing $0.05 \%$ Tween 80 (Oxiteno, Brazil) in a $40 \mathrm{~mL}$ flat bottom glass tube (stock suspension). The conidial suspension was vortexed for $1 \mathrm{~min}$ to produce a homogenous conidial suspension and counted on Neubauer chamber (K5-0111 model, KASVI, Brazil) to obtain a $1 \times 10^{7}$ conidia/mL suspension of each isolate.

\subsubsection{Bioassay}

Petri Dishes with $3.5 \mathrm{~cm}$ of diameter and $1.5 \mathrm{~cm}$ of height were filled with $3 \mathrm{~mL}$ of $0.5 \%$ of water agar and a Jack Bean disc leaf was placed on top of the agar with the abaxial side of the leaf facing up. Thereafter, $12 \mathrm{~T}$. urticae females were transferred by a fine paintbrush in the center of the leaf disc. Each Petri dish was sprayed with $1 \mathrm{~mL}$ of a $1 \times 10^{7}$ conidia/mL suspensions of one isolate with $0.05 \%$ Tween 80 using a Potter Spray Tower (Burkard Manufacturing Co. Ltd., Rickmansworth, Herts, England). The device was adjusted to a pressure of $0.7 \mathrm{psi}$, with an average of $1.5 \mathrm{mg} / \mathrm{cm}^{2}$. To avoid contamination between treatments, the sprayer was cleaned with alcohol and washed three times with distilled water, and the first spray of each treatment was discarded. A control with distilled water plus $0.05 \%$ Tween 80 was included. Five replicates (Petri dishes) were sprayed separately. The entire experiment was repeated three times 
yielding 180 mites per treatment, totalizing 2880 mites used in the entire experiment. The data from the three experiments were analyzed together.

Mortality was recorded daily for 10 days. Dead mites were individually placed in 24 cell well culture plates with a lid on, containing moistened cotton with sterile distilled water to ensure conditions of high relative humidity to allow the growth of fungus on the surface of the cadaver. Mortality caused by fungus was confirmed by microscopic examination.

\subsubsection{Statistical analyses}

The survival parameters of infected mites were analyzed using the KaplanMeier survival analysis using Log Rank (Mantel-Cox) test in SPSS [v. 22.0.0,(2013)]. Quasi-binomial models were fitted to the total mortality and sporulated cadaver's data separately; F-tests were performed to assess significance of effects using a GLM procedure (multcomp R package) through ANOVA. Treatment differences were tested using $95 \%$ confidence intervals using Tukey HSD contrasts. Analyses were performed using the R statistical software environment (R DEVELOPMENT CORE TEAM, 2015).

\subsection{Results}

All Metarhizium isolates were pathogenic to $T$. urticae and differed from untreated control in the survival analyses (Figure 4.1) and Tukey HSD comparison (Figure 4.2). The survival curve of the mites treated with our control isolate, B. bassiana ESALQPL63, was similar to Metarhizium sp. indet. 1 (ESALQ1608 and ESALQ1638), and M. pingshaense (ESALQ3069 and ESALQ3222) but differed from all other isolates [Log Rank (Mantel-Cox) p<0.05], confirming the high efficacy of this isolate. The mites treated with Metarhizium sp. indet. 4 (ESALQ1660 and ESALQ1684), M. brunneum (ESALQ2623) and Metarhizium sp. indet. 5 (ESALQ3140) presented higher survival and differed from all other isolates.

The lowest $\mathrm{LT}_{50}(4 \pm 0.166$ days, $\mathrm{Cl}=3.68-4.32)$ were observed in treatment with Metarhizium sp. indet. 1 ESALQ1638 (Table 4.1). All other treatments did not differ based on comparison of the confidence interval of $L_{50}$. The mites treated with Metarhizium sp. indet. 4 ESALQ1660 presented a LT 50 of $8 \pm 1.487(\mathrm{Cl}=5.08-10.91)$. 
The total mortality of mites (Figure 4.2) treated with the control isolate, $B$. bassiana ESALQPL63, $93 \pm 1.0 \%$ after 10 days of evaluation, was similar to the mortality of eight isolates. Beauveria bassiana ESALQPL63 and Metarhizium sp. indet. 1 (ESALQ1608 and ESALQ1638), differed ( $F=29.92$; $d f=15 ; p<0.001$ ) from $M$. anisopliae (ESALQ2651 and ESALQ3054), M. brunneum (ESALQ2623), Metarhizium sp. indet. 4 (ESALQ1660 and ESALQ1684) [56 $\pm 9.7 \%$ and $59 \pm 2.8 \%]$ and Metarhizium sp. indet. 5 (ESALQ3140), the isolates with lowest mortalities.

The total mortality pattern, in general, followed the pattern of the confirmed mortality. Sporulation was observed in approximately $80 \%$ of spider mite cadavers in all treatments. Mites treated with B. bassiana (ESALQPL63) presented $75 \pm 1.0 \%$ of the cadavers sporulated, and did not differed from eight other isolates. Beauveria bassiana (ESALQPL63) and Metarhizium sp. indet. 1 (ESALQ1608 and ESALQ1638), Metarhizium pingshaense (ESALQ3222), presented higher percentage of sporulation than $(F=67.45 ; \mathrm{df}=15 ; \mathrm{p}<0.001) M$. anisopliae (ESALQ2651 and ESALQ3054), $M$. brunneum (ESALQ2623), Metarhizium sp. indet. 4 [ESALQ1660 (37 $\pm 1.0 \%)$ and ESALQ1684] and Metarhizium sp. indet. 5 (ESALQ3140). 


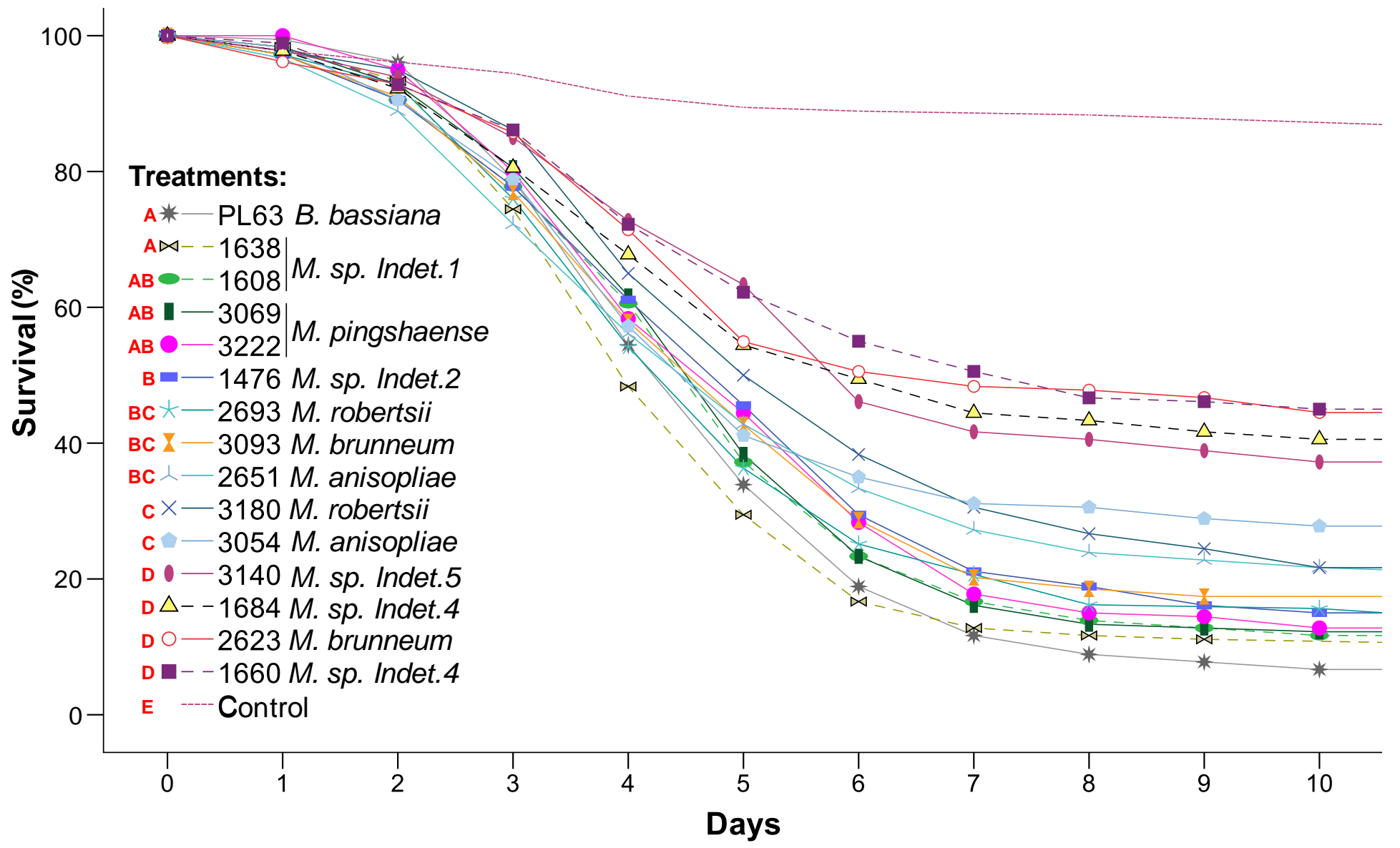

Figure 4.1 - Survival curves of Tetranychus urticae ( $\mathrm{n}=180$ mites per treatment) inoculated with Metarhizium spp. The survival curve refers to the percentage of mites surviving up to 10 days post-treatment. Different letters indicate differences among treatments [Log Rank (Mantel-Cox) $p<0.05]$ 


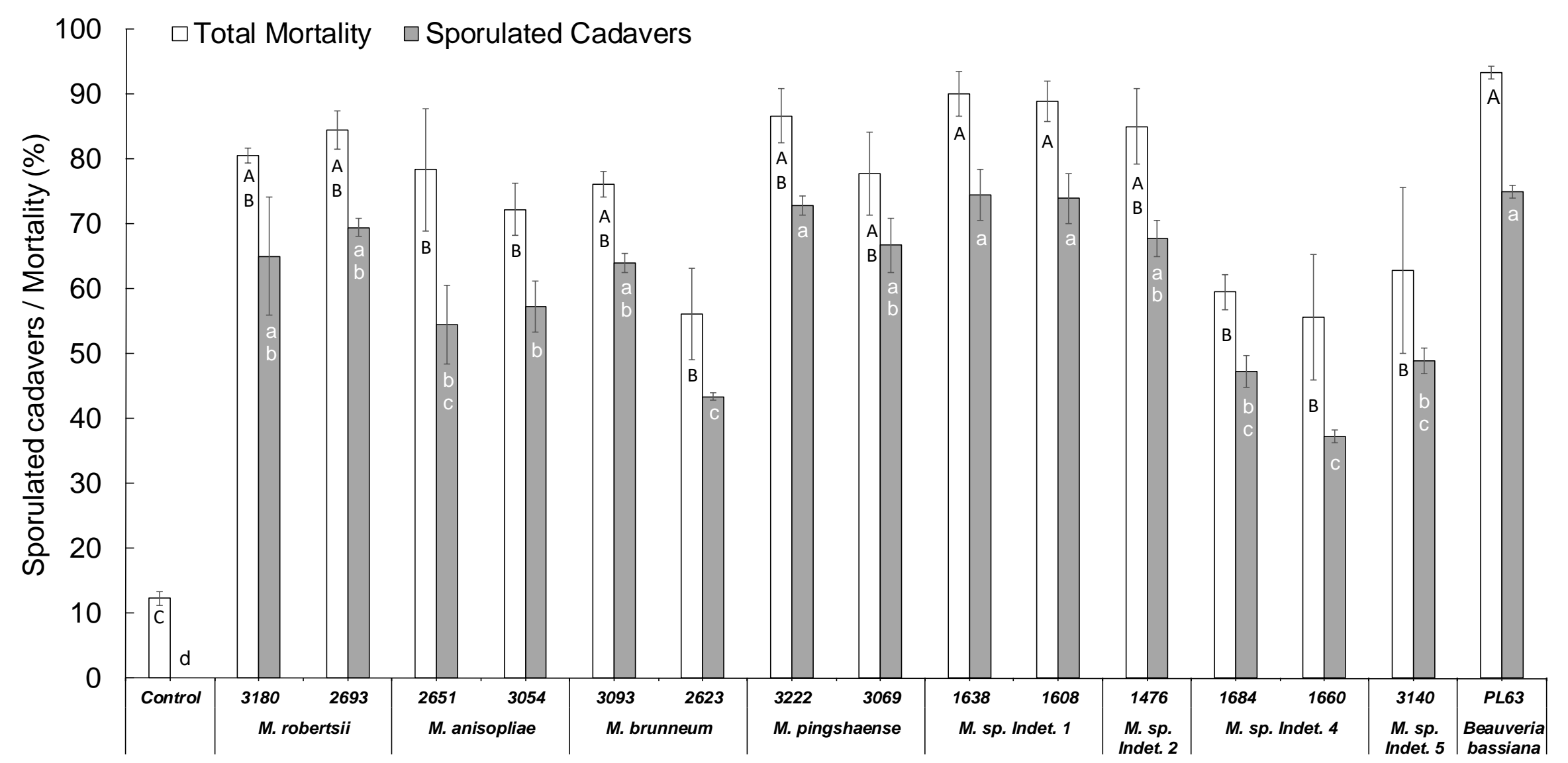

Figure 4.2 - Mortality and sporulated cadavers of Tetranychus urticae females at $25^{\circ} \mathrm{C}$ and $12: 12 \mathrm{~L}: \mathrm{D} 10$ days after being sprayed with 14 isolates of Metarhizium spp. or Beauveria bassiana (isolate ESALQPL63) with 0.05\% Tween-80. Different lowercase letters indicate treatment differences in sporulated cadavers; different upper-case letters indicate treatment differences in total mortality by quasi-binomial models and F-tests through ANOVA and Tukey HSD comparison $(p<0.05)$

Table 4.1 - Origin of Metarhizium spp. and Beauveria bassiana isolates and Median Lethal Time (LT50 \pm SE) of Tetranychus urticae mites sprayed with each isolate 


\begin{tabular}{|c|c|c|c|c|c|c|}
\hline $\begin{array}{c}\text { Collection } \\
\text { Number } \\
\text { (ESALQ) }\end{array}$ & Species & $\begin{array}{c}\text { Type of isolation: } \\
\text { Origen }{ }^{1}\end{array}$ & City & Environment & $\begin{array}{l}\mathrm{LT}_{50} \\
( \pm \mathrm{SE})\end{array}$ & $\mathrm{Cl}^{2}$ \\
\hline 3180 & M. robertsii & IB: Soil & Estiva / MG & Strawberry & $5( \pm 0.28)$ & $(4.45-5.55)$ \\
\hline 2693 & M. robertsii & SM: Rhizosphere & Inconfidentes / MG & Strawberry & $5( \pm 0.18)$ & $(4.65-5.35)$ \\
\hline 2651 & M. anisopliae & Insect Bait: Soil & Cambuí / MG & Strawberry & $5( \pm 0.28)$ & $(4.46-5.54)$ \\
\hline 3054 & M. anisopliae & SM: Rhizosphere & Inconfidentes / MG & Strawberry & $5( \pm 0.23)$ & $(4.55-5.45)$ \\
\hline 3093 & M. brunneum & IB: Soil & Senador Amaral / MG & Strawberry & $5( \pm 0.24)$ & $(4.52-5.48)$ \\
\hline 2623 & M. brunneum & IB: Soil & Inconfidentes / MG & Strawberry & $7( \pm 0.83)$ & (5.38-8.62) \\
\hline 3222 & M. pingshaense & IB: Soil & Estiva / MG & Strawberry & $5( \pm 0.27)$ & $(4.48-5.52)$ \\
\hline 3069 & M. pingshaense & IB: Soil & Cambuí / MG & Strawberry & $5( \pm 0.15)$ & $(4.70-5.30)$ \\
\hline 1638 & Metarhizium sp. Indet.1 ${ }^{*}$ & IB: Soil & Rio Verde / GO & Cerrado & $4( \pm 0.17)$ & (3.68-4.32) \\
\hline 1608 & Metarhizium sp. Indet. $1^{*}$ & IB: Soil & Rio Verde / GO & Cerrado & $5( \pm 0.15)$ & $(4.70-5.30)$ \\
\hline 1476 & Metarhizium sp. Indet.2* & IB: Soil & Cambuí / MG & Strawberry & $5( \pm 0.23)$ & $(4.54-5.46)$ \\
\hline 1684 & Metarhizium sp. Indet.4* & SM: Rhizosphere & Iracemapolis / SP & Sugar Cane & $6( \pm 0.48)$ & $(5.06-6.94)$ \\
\hline 1660 & Metarhizium sp. Indet. $4^{*}$ & IB: Soil & Piracicaba / SP & Sugar Cane & $8( \pm 1.49)$ & $(5.08-10.91)$ \\
\hline 3140 & Metarhizium sp. Indet. $5^{*}$ & IB: Soil & Cambuí / MG & Strawberry & $6( \pm 0.34)$ & $(5.33-6.67)$ \\
\hline PL63 & Beauveria bassiana & Insect & Piracicaba / SP & Atta sp. & $5( \pm 0.16)$ & $(4.69-5.31)$ \\
\hline
\end{tabular}

${ }^{\overline{ }}$ New Metarhizium spp. not yet described. ${ }^{1} \mathrm{IB}=$ Insect Baiting $\mathrm{SM}=$ Selective Medium ${ }^{2} \mathrm{Cl}=$ confidence interval of $\mathrm{LT} 50$ 


\subsection{Discussion}

Although all the 14 fungal isolates tested were able to infect adult female of $T$. urticae mite in laboratory, there were significant variations amongst the isolates. These results revealed the potential of the unassigned new lineages of Metarhizium as biocontrol agents. Metarhizium sp. Indet. 1 ESALQ1638, stands out by presenting the lowest $\mathrm{LT}_{50}$ and it was similar to the best isolates, including B. bassiana (ESALQPL63) registered against this pest, when considering the other parameters (survival curve, total mortality and sporulated cadavers). Metarhizium sp. Indet. 1 (ESALQ1608) and M. pingshaense (ESALQ3069 and ESALQ3222) were as good as the isolates of the more studied and commercial available Metarhizium species: $M$. anisopliae, $M$. brunneum and $M$. robertsii.

Even though $M$. anisopliae is most frequently species found naturally infecting insects in Brazil (REZENDE, 2014; IWANICKI, 2016) and it is the only species used in all commercial products in the country, all other species tested here, except Metarhizium sp. Indet. 4 and Metarhizium sp. Indet. 5, presented at least one isolate among the best against $T$. urticae in all parameters. Variations between isolates in the virulence of $M$. anisopliae have been reported in T. urticae (TAMAl et al., 2002; CHANDLER et al., 2005; BUGEME et al., 2008). Based on the new classification of Metarhizium (BISCHOFF et al., 2009) it is likely that Chandler et al. (2005) and Bugeme et al. (2008), had compared isolates from diferent species of Metarhizium. However, we now know that the isolates used by Tamai et al. (2002) is probably $M$. anisopliae based on later studies on molecular identification of ESALQ collection of Metarhizium (REZENDE, 2014).

The control levels obtained in our study was similar to other laboratory screenhouse and field studies elsewhere. Chandler et al. (2005) showed reductions of all developmental stages (eggs, nymphs, and adults) of $T$. urticae when $M$. anisopliae was applied; they also studied the efficacy of Naturalis-L (B. bassiana-based mycopesticide - Troy Biosciences, Phoenix, TX, USA) which reduced T. urticae populations by $97 \%$. Up to $93 \%$ and $96 \%$ reductions in T. urticae population density on cucumber and tomato, respectively, was observed following application of Naturalis-L (MARCIC et al., 2012). Bugeme et al. (2015) recently reported that $M$. anisopliae formulations were as effective as abamectin (conventional chemical control) in reducing $T$. urticae densities on common bean in both screenhouse and field experiments. An emulsifiable formulation of $M$. anisopliae was tested in the control of five Tetranychidae mites 
including $T$. urticae in irrigated cotton fields in a desert area on the Tarim Basin of northwestern China and a high potential for practical use in the management of the spider mites using this technique was found (SHI et al., 2008).

The potential of $M$. pingshaense for pest control was largely unexplored. The pathogenicity of $M$. pingshaense isolate MGC02 caused more than $80 \%$ larval mortality of Anomala cincta (Coleoptera: Scarabeidae) in laboratory assays (GUZMÁNFRANCO et al., 2011). Pena-Pena et al. (2015) reported that the same isolate has a potential in controlling root-feeding pests by seed inoculation, confirming its ability to endophytic colonize the maize roots.

This study revealed for the first time the potential of new and less studied species of Metarhizium as biocontrol agent of $T$. urticae. These less known species should be considered in further studies to assess their potential as biological control agents of other pest in the future.

\section{Acknowledgments}

This research was funded by the Danish Agency for Science, Technology and Innovation and The São Paulo Research Foundation (through the project IMBICONT: 'Improved biological control for IPM in fruits and berries', project number 0603-00486B and 2011/51556-3 respectively). The first author is a recipient of scholarships from the São Paulo Research Foundation (FAPESP, project number 2013/24430-4 and 2013/10517-0).

\section{References}

AMJAD, M.; BASHIR, M.H.; AFZAL, M.; SABRI, M.A.; JAVED, N. Synergistic effect of some entomopathogenic fungi and synthetic pesticides, against Two spotted spider mite, Tetranychus urticae Koch (Acari: Tetranychidae). Pakistan Journal of Zoology, Lahore, v. 44, n. 4, p. 977-984, 2012.

ATTIA, S.; GRISSA, K.L.; LOGNAY, G.; BITUME, E.; HANCE, T.; MAILLEUX, A.C. A review of the major biological approaches to control the worldwide pest Tetranychus urticae (Acari: Tetranychidae) with special reference to natural pesticides. Journal of Pest Science, Innsbruck, v. 86, n. 3, p. 361-386, 2013. 
BISCHOFF, J.F.; REHNER, S.A.; HUMBER, R.A. A multilocus phylogeny of the Metarhizium anisopliae lineage. Mycologia, New York, v. 101, n. 4, p. 512-530, 2009.

BUGEME, D.M.; KNAPP, M.; BOGA, H.I.; WANJOYA, A.K.; MANIANIA, N.K. Influence of temperature on virulence of fungal isolates of Metarhizium anisopliae and Beauveria bassiana to the Two spotted spider mite Tetranychus urticae. Mycopathologia, Den Haag, v. 167, n. 4, p. 221-227, 2008.

BUGEME, D.M.; MANIANIA, N.K.; KNAPP, M.; BOGA, H.I. Effect of temperature on virulence of Beauveria bassiana and Metarhizium anisopliae isolates to Tetranychus evansi. Experimental and Applied Acarology, Amsterdam, v. 46, n. 1/4, p. 275285, 2008.

BUGEME, D.M.; KNAPP, M.; EKESI, S.; CHABI-OLAYE, A.; BOGA, H.I.; MANIANIA, N.K. Efficacy of Metarhizium anisopliae in controlling the two-spotted spider mite Tetranychus urticae on common bean in screenhouse and field experiments. Insect Science, Malden, v. 22, n. 1, p. 121-128, 2015.

CHANDLER, D.; DAVIDSON, G.; JACOBSON, R.J. Laboratory and glasshouse evaluation of entomopathogenic fungi against the Two spotted spider mite, Tetranychus urticae (Acari: Tetranychidae), on tomato, Lycopersicon esculentum. Biocontrol Science and Technology, Oxford, v. 15, n. 1, p. 37-54, 2005.

DE MORAES, G.J.; FLECHTMANN, C.H.W. Manual de acarologia: acarologia básica e ácaros de plantas cultivadas no Brasil. Ribeirão Preto: Holos, 2008. 308 p.

FARIA, M.R.D.; WRAIGHT, S.P. Mycoinsecticides and mycoacaricides: a comprehensive list with worldwide coverage and international classification of formulation types. Biological Control, Orlando, v. 43, n. 3, p. 237-256, 2007.

GUZMÁN-FRANCO, A.W.; HERNÁNDEZ-LÓPEZ, J.; ENRÍQUEZ-VARA, J.N.; ALATORRE-ROSAS, R.; TAMAYO-MEJÍA, F.; ORTEGA-ARENAS, L.D. Susceptibility of Phyllophaga polyphylla and Anomala cincta larvae to Beauveria bassiana and Metarhizium anisopliae isolates, and the interaction with soil properties. BioControl, Dordrecht, v. 57, n. 4, p. 553-563, 2011.

IBM CORP. IBM SPSS statistics for windows: version 22.0. Armonk, 2013.

IWANICKI, N.S. Monitoramento de Metarhizium spp. (Hypocreales:

Clavicipitaceae) por marcadores moleculares em plantios de cana-de-açúcar. 2016. 68 p. Dissertação (Mestrado em Entomologia) - Escola Superior de Agricultura "Luiz de Queiroz", Universidade de São Paulo, Piracicaba, 2016.

IWASSAKI, L.A.; SATO, M.E.; CALEGARIO, F.F.; POLETTI, M.; MAIA ADE, H. Comparison of conventional and integrated programs for control of Tetranychus urticae (Acari: Tetranychidae). Experimental and Applied Acarology, Amsterdam, v. 65, n. 2, p. 205-217, 2015. 
LOPES, R.B.; SOUZA, D.A.; OLIVEIRA, C.M.; FARIA, M. Genetic diversity and pathogenicity of Metarhizium spp. associated with the white grub Phyllophaga capillata (Blanchard) (Coleoptera: Melolonthidae) in a soybean field. Neotropical Entomology, Londrina, v. 42, n. 4, p. 436-438, 2013.

LOPES, R.B.; FARIA, M.; SOUZA, D.A.; BLOCH, C. JR.; SILVA, L.P.; HUMBER, R.A. MALDI-TOF mass spectrometry applied to identifying species of insectpathogenic fungi from the Metarhizium anisopliae complex. Mycologia, New York, v. 106, n. 4 , p. $865-878,2014$.

LOPES, R.B.; MESQUITA, A.L.M.; TIGANO, M.S.; SOUZA, D.A.; MARTINS, I.; FARIA, M. Diversity of indigenous Beauveria and Metarhizium spp. in a commercial banana field and their virulence toward Cosmopolites sordidus (Coleoptera: Curculionidae). Fungal Ecology, Cardiff, v. 6, n. 5, p. 356-364, 2013.

MANIANIA, N.K.; BUGEME, D.M.; WEKESA, V.W.; DELALIBERA, I. JR.; KNAPP, M. Role of entomopathogenic fungi in the control of Tetranychus evansi and Tetranychus urticae (Acari: Tetranychidae), pests of horticultural crops.

Experimental and Applied Acarology, Amsterdam, v. 46, n. 1/4, p. 259-274, 2008.

MARCIC, D.; PRIJOVIC, M.; DROBNJAKOVIC, T.; MEDJO, I.; PERIC, P.; MILENKOVIC, S. Greenhouse and field evaluation of two biopesticides against Tetranychus urticae and Panonychus ulmi (Acari: Tetranychidae). Pesticidi i Fitomedicina, Zemun, v. 27, n. 4, p. 313-320, 2012.

NICASTRO, R.L.; SATO, M.E.; DA SILVA, M.Z. Milbemectin resistance in Tetranychus urticae (Acari: Tetranychidae): selection, stability and cross-resistance to abamectin. Experimental and Applied Acarology, Amsterdam, v. 50, n. 3, p. 231-241, 2010.

PENA-PENA, A.J.; SANTILLAN-GALICIA, M.T.; HERNANDEZ-LOPEZ, J.; GUZMAN-FRANCO, A.W. Metarhizium pingshaense applied as a seed treatment induces fungal infection in larvae of the white grub Anomala cincta. Journal of Invertebrate Pathology, San Diego, v. 130, p. 9-12, 2015.

QUINELATO, S.; GOLO, P.S.; PERINOTTO, W.M.; SA, F.A.; CAMARGO, M.G.; ANGELO, I.C.; MORAES, A.M.; BITTENCOURT, V.R. Virulence potential of Metarhizium anisopliae s.l. isolates on Rhipicephalus (Boophilus) microplus larvae. Veterinary Parasitology, Amsterdam, v. 190, n. 3/4, p. 556-565, 2012.

R DEVELOPMENT CORE TEAM. R: a language and environment for statistical computing. Vienna: R Foundation for Statistical Computing, 2015. Disponível em: <http://www.R-project.org >. Acesso em: 05 fev. 2016.

REZENDE, J.M. Diversidade filogenética e expressão de genes de virulência de Metarhizium com ênfase em isolados brasileiros associados a cultura da canade-açúcar. 2014. 138 p. Tese (Doutorado em Entomologia) - Escola Superior de Agricultura "Luiz de Queiroz", Universidade de São Paulo, Piracicaba, 2014. 
REZENDE, J.M.; ZANARDO, A.B.R.; LOPES, M.D.; DELALIBERA, I.; REHNER, S.A. Phylogenetic diversity of Brazilian Metarhizium associated with sugarcane agriculture. BioControl, Dordrecht, v. 60, n. 4, p. 495-505, 2015.

SHI, W.-B.; ZHANG, L.-L.; FENG, M.-G. Field trials of four formulations of Beauveria bassiana and Metarhizium anisoplae for control of cotton spider mites (Acari:

Tetranychidae) in the Tarim Basin of China. BioControl, Dordrecht, v. 45, n. 1, p. 4855, 2008.

STUMPF, N.; NAUEN, R. Cross-resistance, inheritance, and biochemistry of mitochondrial electron transport inhibitor-acaricide resistance in Tetranychus urticae (Acari : Tetranychidae). Journal of Economic Entomology, Lanham, v. 94, n. 6, p. 1577-1583, 2001.

TAMAI, M.A.; ALVES, S.B.; DE ALMEIDA, J.E.M.; FAION, M. Evaluation of entomopathogenic fungi for control of Tetranychus urticae koch (acari:

Tetranychidae). Arquivos do Instituto Biológico, São Paulo, v. 69, n. 3, p. 77-84, 2002.

TAVASSOLI, M.; ALLYMEHR, M.; POURSEYED, S.H.; OWNAG, A.; BERNOUSI, I.; MARDANI, K.; GHORBANZADEGAN, M.; SHOKRPOOR, S. Field bioassay of Metarhizium anisopliae strains to control the poultry red mite Dermanyssus gallinae. Veterinary Parasitology, Amsterdam, v. 178, n. 3/4, p. 374-8, 2011.

VEGA, F.E.; MEYLING, N.V.; LUANGSA-ARD, J.J.; BLACKWELL, M. Fungal entomopathogens. In: VEGA, F.E.; KAYA, H.K. (Ed.). Insect pathology. San Diego: Academic Press, 2012. chap. 6, p. 171-220.

WEKESA, V.W.; MANIANIA, N.K.; KNAPP, M.; BOGA, H.I. Pathogenicity of Beauveria bassiana and Metarhizium anisopliae to the tobacco spider mite Tetranychus evansi. Experimental and Applied Acarology, Amsterdam, v. 36, n. 1/2, p. 41-50, 2005.

ZANARDO, A.B.R. Abundância de fungos entomopatogênicos da ordem Hypocreales e diversidade genética de Metarhizium spp. isolados de amostras de solo de áreas representativas de cinco biomas brasileiros. 2015. 154 p. Tese (Doutorado em Entomologia) - Escola Superior de Agricultura "Luiz de Queiroz", Universidade de São Paulo, Piracicaba, 2015. 